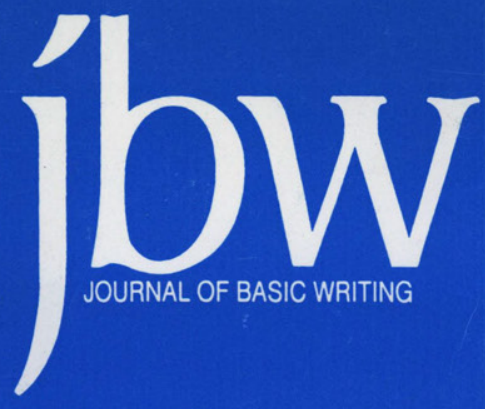

\title{
SPRING 2000
}

VOLUME 19 NUMBER 1

Basic Writing and the Issue of Correctness, or, What to Do with "Mixed" Forms of Academic Discourse Patricia Bizzell

Meanness and Failure: Sanctioning Basic Writers Terence Collins and Melissa Blum

Basic Writing, Cost Effectiveness, and Ideology *

Keith Gilyard

Going Around in Circles:

Methodological Issues in Basic Writing Research William DeGenaro and Edward M. White

Expectations, Interpretations and Contributions of Basic Writing Min-Zhan Lu and Bruce Horner

A Future for the Vanishing Present: New Work for Basic Writing Susan Miller

The Strategic Value of Basic Writing:

An Analysis of the Current Moment Deborah Mutnick

Basic Work and Material Acts: The Ironies, Discrepancies, and Disjunctures of Basic Writing and Mainstreaming Judith Rodby and Tom Fox

Illegal Literacy Ira Shor

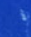

How We Have Failed the Basic Writing Enterprise Lynn Quitman Troyka 


\title{
A New Text for Developmental English by Kirszner and Mandell
}

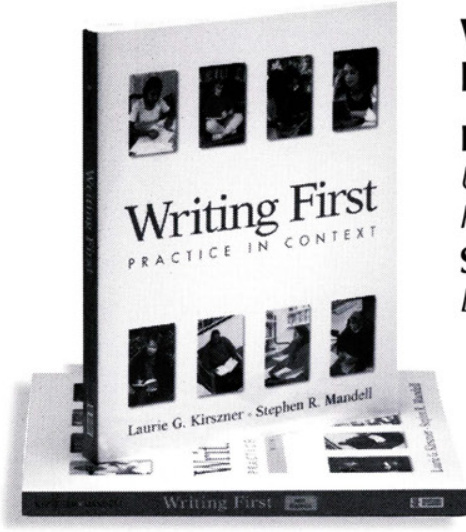

\author{
WRITING FIRST \\ Practice in Context
}

Laurie G. Kirszner

University of the Sciences in

Philadelphia

Stephen R. Mandell

Drexel University

2000/PAPER/624 PAGES

WITHOUT READINGS: 560 PAGES

Extensive ANCILLARY PACKAGE

Writing First: Practice in Context is the only developmental workbook that places primary emphasis on students' own writing while at the same time providing ample opportunity for practice and drill. Addressing students as serious writers and giving them the support they need, Kirszner and Mandell help them lay a solid foundation for success in college.

- Comprehensive coverage in a flexible format. The book offers a process approach to teaching writing, with 11 chapters about the paragraph and a separate, complete chapter on essay writing.

- A unique, practice-in-context approach. Each chapter gets students writing immediately. As students use their own drafts to practice writing skills, they also complete workbook-style mastery exercises that reinforce those skills.

a user-friendly design. The engaging, full-color design highlights key information and includes many helpful navigation features.

"This is the best developmental writing text I have ever seen. It covers everything from sentence mechanics to writing a research paper. The students will learn to examine their own writing with a critical eye and then revise.

Whether you offer one developmental writing course or two, this is the only book you need." 


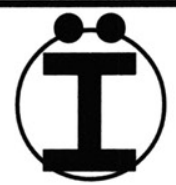

The paper used in this publication meets the minimum requirements of the American National Standard for Information Science Permanence of Paper for Printed Library Materials, ANSI Z39.48-1984.

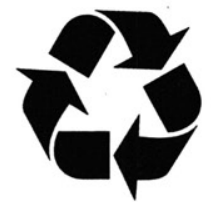

The text stock is also recycled.

\section{This publication is available in microform from UMI.}

Please send me information about the titles I've listed below:

Name

Title

Company/Institution

Address

City/State/Zip

Phone (_

\section{$\mathrm{U} \cdot \mathrm{M} \cdot \mathrm{I}$}

A Bel I \& Howell Company

300 North Zeeb Road, Ann Arbor, M 48106 USA 800-521-0600 toll-free 313-761-4700 collect from Alaska and Michigan 800-343-5299 toll-free from Canada 



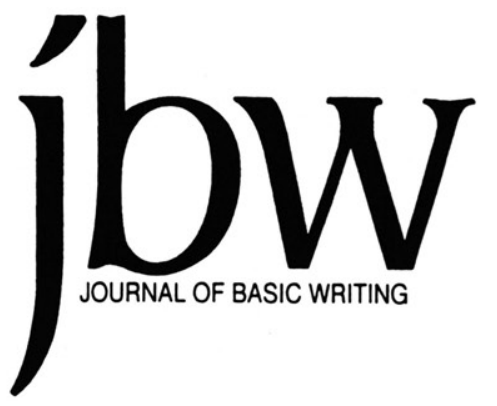

VOLUME 19

SPRING 2000

The Journal of Basic Writing publishes articles of theory, research, and teaching practices related to basic writing. Articles are refereed by members of the Editorial Board (see overleaf) and the Editors.

\section{George Otte and Trudy Smoke Editors}

\section{Rhona Cohen and Mikhail Gershovich Editorial Assistants}

\section{Mary E. Carney, Subscriptions}

The Journal of Basic Writing is published twice a year, in the spring and fall. We welcome unsolicited manuscripts and ask authors to consult the detailed "Call for Articles" in this issue. Subscriptions for individuals are $\$ 15.00$ for one year and $\$ 28.00$ for two years; subscriptions for institutions are $\$ 20.00$ for one year and $\$ 38.00$ for two years. Foreign postage is $\$ 5.00$ extra per year. ADDRESS:

Journal of Basic Writing

City University of New York

555 West 57 Street, Room 1601

New York, NY 10019 


\section{JOURNAL OF BASIC WRITING}

\section{EDITORIAL BOARD}

Peter Dow Adams

Essex Community College, Baltimore

Akua Duku Anokye

University of Toledo

Chris M. Anson

North Carolina State University

David Bartholomae

University of Pittsburgh

Sarah Benesch

College of Staten Island, CUNY

Bill Bernhardt

College of Staten Island, CUNY

Patricia Bizzell

College of the Holy Cross

Lynn Z. Bloom

University of Connecticut, Storrs

Nancy Carriuolo

University of New Haven

Richard Courage

Westchester Community College, SUNY

Donald Daiker

Miami University

Suellynn Duffey

Ohio University

Sarah Warshauer Freedman

University of California, Berkeley

Karen L. Greenberg

Hunter College, CUNY

Brenda M. Greene

Medgar Evers College, CUNY

Muriel Harris

Purdue University

Irvin Hashimoto

Whitman College

Warren Herendeen

Mercy College

Myra Kogen

Brooklyn College, CUNY
Patricia Ondek Laurence

City College, CUNY

Elaine 0 . Lees

Carlow Hill College

Andrea A. Lunsford

Ohio State University

Jane Maher

Nassau Community College

Peter Miller

College of Staten Island, CUNY

Susan Miller

University of Utah

Nathaniel Norment, Jr.

Temple University

Jerrold Nudelman

Queensborough Community

College, CUNY

Jane Peterson

Richland College, Dallas County

Community College Distnct

Nell Ann Pickett

Hinds Community College

Charles I. Schuster

University of Wisconsin, Milwaukee

Tony Silva

Purdue University

Lynn Quitman Troyka

Oueensborough Community

College, CUNY, ret.

Karen S. Uehling

Boise State University

Billie J. Wahlstrom

University of Minnesota

Evelyn E. Webb

Mississippi State Board for

Community and Junior Colleges

Harvey S. Wiener

Marymount Manhattan College 


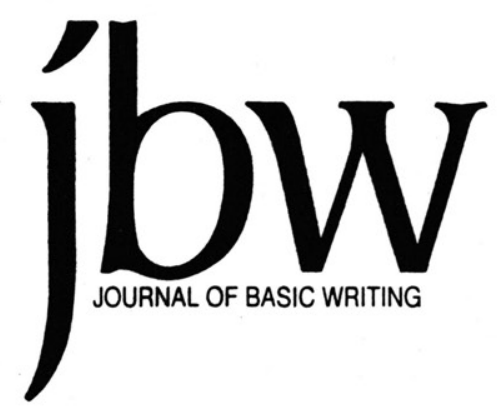

VOLUME 19

NUMBER 1

SPRING 2000

Editors' Column

Basic Writing and the Issue of Correctness, or,

What to Do with "Mixed" Forms of Academic Discourse

Patricia Bizzell

Meanness and Failure: Sanctioning Basic Writers

Terence Collins and Melissa Blum

Going Around in Circles:

Methodological Issues in Basic Writing Research

William DeGenaro and Edward M. White

Basic Writing, Cost Effectiveness, and Ideology

Keith Gilyard

Expectations, Interpretations and Contributions of Basic Writing Min-Zhan Lu and Bruce Horner

A Future for the Vanishing Present: New Work for Basic Writing Susan Miller

The Strategic Value of Basic Writing:

An Analysis of the Current Moment

Deborah Mutnick

Basic Work and Material Acts: The Ironies, Discrepancies, and Disjunctures of Basic Writing and Mainstreaming

Judith Rodby and Tom Fox

Illegal Literacy

Ira Shor

How We Have Failed the Basic Writing Enterprise

Lynn Quitman Troyka

News and Announcements 


\section{CALL FOR ARTICLES}

We welcome manuscripts of $10-20$ pages on topics related to basic writing, broadly interpreted.

Manuscripts will be refereed anonymously. We require five copies of a manuscript and an abstract of about 100 words. To assure impartial review, give author information and a short biographical note for publication on the cover page only. Papers which are accepted will eventually have to supply camera-ready copy for all ancillary material (tables, charts, etc.). One copy of each manuscript not accepted for publication will be returned to the author, if we receive sufficient stamps (no meter strips) clipped to a self-addressed envelope. Submissions should follow current MLA guidelines.

All manuscripts must focus clearly on basic writing and must add substantively to the existing literature. We seek manuscripts that are original, stimulating, well-grounded in theory, and clearly related to practice. Work that reiterates what is known or work previously published will not be considered.

We invite authors to write about such matters as classroom practices in relation to basic writing theory; cognitive and rhetorical theories and their relation to basic writing, social, psychological, and cultural implications of literacy; discourse theory, grammar, spelling, and error analysis; linguistics; computers and new technologies in basic writing; English as a second language; assessment and evaluation; writing center practices; teaching logs and the development of new methodologies; and cross-disciplinary studies combining basic writing with psychology, anthropology, journalism, and art. We publish observational studies as well as theoretical discussions on relationships between basic writing and reading, or the study of literature, or speech, or listening. The term "basic writer" is used with wide diversity today, sometimes referring to a student from a highly oral tradition with little experience in writing academic discourse, and sometimes referring to a student whose academic writing is fluent but otherwise deficient. To help readers therefore, authors should describe clearly the student population which they are discussing.

We particularly encourage a variety of manuscripts: speculative discussions which venture fresh interpretations; essays which draw heavily on student writing as supportive evidence for new observations; research reports, written in nontechnical language, which offer observations previously unknown or unsubstantiated; and collaborative writings which provocatively debate more than one side of a central controversy. 


\section{EDITORS' COLUMN}

We swear: it wasn't millennial fever - the Y2K bug everyone did have to deal with - that made us do it. The idea for this special issue took root early in the development of the Fall ' 99 issue. The real impetus was that issue's challenge to us to find an appropriate way of following it up. It had precisely the interrelated themes our field and readership need to take into account: the "disappearing" of basic writers and basic writing programs by political mandate, considerations of basic writing's relations to assessment and academic discourse, above all, several janus-like looks at the way basic writing and basic writers had been and should be defined. An issue that rich made us think: was theresome way to make the interrelations (especially between the field's past and future) still more explicit, its exigencies still more compelling? We listed the people readers of JBW might particularly like to hear from, some who had helped to define and others to interrogate this field so full of change. The list begat a letter inviting contributions to an issue that would look both back and ahead. (The letter mentioned that, for thirty seconds, we thought of nominating the theme "Whither Basic Writing?" - and then realized what a bad, sad pun we had stumbled on.)

The excitement we felt at the generous acceptances escalated considerably as the articles themselves came in. Journal editors are often blessed with fortuitous connections, articles in the same issue that somehow seem to speak to each other, but we had never seen this to such an amazing extent. These articles light up each other in so many ways we finally decided the only acceptable arrangement would be something as emphatically arbitrary as alphabetical order. We are tempted to urge that where to begin in this issue and what to read next might be best determined by casting lots. Like some modern day Book of Changes, the issue invites individualized, almost infinite pairings and groupings, comparisons and cross-references. All the articles have much to say about where basic writing should go and has been, that much more to say when the thoughts of one article are seen to send ripples through others. We hesitate to say much more than this, but we also concede that it's the editors' duty to give reductive little sketches of what rich canvases actually represent.

Some of the authors locate a future for basic writing within the larger landscape. Min-Zhan Lu and Bruce Horner suggest that the whole academy, caught up in the advocacy of diversity, of studentcentered learning, of border crossings and hybridities, ought to be drawn to basic writing and basic writers - and drawn as much to learn 
as to teach. Patricia Bizzell, seeing monolithic ideas of academic discourse as possibly mythic and increasingly untenable, notes that increasingly mixed discourse(s) should invite a reconception of the work of basic writing, especially the old call to inculcate correctness. Susan Miller invites us to look beyond the walls of the academy to other sites of instruction and shared interest; if, as she suggests, basic writing is the canary in composition's coal mine, the re-situating she proposes has an interest ranging well beyond basic writing.

There are other visions of moving beyond and leaving behind. Ira Shor, whose labeling of basic writing as "Our Apartheid" (in the Spring '97 JBW) has sparked such controversy, does not so much revisit his argument as confront it on personal terms, forced to advise students who have slipped past basic writing to regular composition and so seem guilty of what he calls "Illegal Literacy"; their plight has him puzzling through power of tests to create what he calls "structured inequality." Judith Rodby and Tom Fox have a happier tale to tell, but one that is very much to the same point: their experience at $\mathrm{Cal}$ State, Chico, suggests that mainstreaming low-scoring students does work, particularly when students are provided support that chimes with but also expands our notions of sound pedagogy.

Other scholars argue for holding to the hard-won space that basic writing represents. Keith Gilyard, a supporter as well as an evaluator of a key mainstreaming experiment, resists embracing Shor's vision of a future without basic writing, a vision he feels may erase or erode too much. Like Gilyard, Deborah Mutnick finds Shor's questions more useful than his answers; if basic writing is "our apartheid," she suggests that its elimination will result in something less like the desegregation of higher education than its resegregation. Terence Collins and Melissa Blum may make this point most poignantly, showing what the loss of basic writing meant to students who had only a taste, a peek through the open-access door, before political change slammed it shut.

As for why such estimable teacher-scholars reach such different conclusions, William DeGenaro and Edward M. White argue that these spring from still deeper divergences, disparate and even incompatible roles and first premises, with the consequence that our scholarly discussions may be more circular than constructive. Lynn Quitman Troyka also sees the urgencies of basic writing as rooted in research, but for her the story is more of missed chances than missed meanings, of failed opportunities to tell the story of basic writing (or at least set it straight); seeing a problem may not solve it, but it does create the hope of finding a solution, maybe even before it's too late.

As we said, these little thumbnail sketches are inevitably reductive. Bizzell, Miller, or Lu and Horner should not be thought to have less to say about research than Troyka or DeGenaro and White, for 
instance, and all the pieces speak to the debate about the status of basic writing - some more directly but none narrowly - and so throw off implications and ramifications. Most of all, all these pieces resonate and reverberate with and through each other. Read them as you will. Create your own ripple effect.

-- George Otte and Trudy Smoke 


\section{BASIC WRITING AND THE ISSUE OF CORRECTNESS, OR,WHAT TO DO WITH "MIXED" FORMS OF ACADEMIC DISCOURSE}

ABSTRACT: Basic writing instruction has focused on the problem of how to enable underprepared college students to write correct academic discourse. This definition of basic writing, work assumes that there is a single stable entity called "academic discourse." If this was ever true, it is no longer. Published scholarship in many fields may now take the form of discourses in which the traditional academic mixes with non-academic discourses. These mixed discourses emerge as scholars wish to take full advantage of all the discursive resources at their disposal, reflecting the extent to which more and more people are culturally mixed. These discourses also enable people to do academic work that could be done no other way. These discourses should not be called "hybrid," perhaps, because the term is at once too essentializing and too suggestive of independent "parent" strands. But we should find ways to encourage them in our teaching.

"Correctness" is a perennial issue in basic writing instruction. As I have recently suggested in "Hybrid Academic Discourses: What, Why, How" (1999), the historical development of basic writing instruction can be seen in three phases. The first, dating to about twenty years ago, depicted as cognitively deficient those students who could not produce academic writing that allowed them to succeed in school, and recommended as a remedy the strict inculcation of traditional academic discourse. "Correctness" was a relatively unproblematic issue here; it seemed relatively obvious that "basic writers" were those who could not write Standard English correctly and who were unfamiliar with academic discourse forms. For example, Andrea Lunsford's 1980 essay "The Content of Basic Writers' Essays" treats the reliance of basic writers upon personal experience in their arguments as one sign of their arrest at an early stage of Piagetian or Vygotskean cognitive development.

The second phase, with which my own earlier work is associ-

Patricia Bizzell is Professor of English at the College of the Holy Cross, where she teaches firstyear composition, American literature, and rhetoric. She has directed the Writers Workshop, a peer tutoring facility; the Writing Across the Curriculum Program; the College Honors Program; and presently, the English Honors Program. Among her publications is the fifth edition of The Bedford Bibliography for Teachers of Writing, co-authored with Bruce Herzberg and Nedra Reynolds (February 2000). 
ated, attacked this characterization of struggling students because it ignored their real abilities with language. Second-phase scholars aimed to initiate students into traditional academic discourse in a way that remained respectful of their home languages and cognitive abilities. An example is my 1986 essay "What Happens When Basic Writers Come to College?", in which basic writers' difficulties are attributed primarily to clashes between their home world views and the academic world view, and their home discourse communities' resources are acknowledged. Be it noted, however, that here, too, the issue is still "correctness." That is, basic writers are still defined by the seemingly obvious fact that they do not produce Standard English and traditional academic discourse, and this situation is treated as a problem that needs to be remedied. Indeed, it could be argued that in spite of theoretical nuances debated over the years, the field of basic writing instruction still relies upon relatively obvious features of student writing as a basis for sorting students into basic writing courses. We quickly read a large number of writing samples, as the sorting process often goes, and the ones exhibiting many features of non-Standard English and non-academic discourse forms land their authors in basic writing classes, where their writing "problems" are supposed to be addressed.

In my "Hybrid Academic Discourses" essay cited above, I argue for a significant change in our orientation toward correctness. I try to launch a third phase in basic writing pedagogy, in which the unitary nature of traditional academic discourse as a target for composition teaching is called into question, on the basis of the proliferation in contemporary academic writing of forms that do not follow traditional criteria. If we look at published work in the field of composition studies, for example, such as that of Keith Gilyard, Geneva Smitherman, or Victor Villanueva, whose book Bootstraps (1993) I discuss in detail in the "Hybrid Academic Discourses" essay, we will see that Standard English and traditional academic discourse are no longer the only discursive resources used for serious intellectual work. These scholars, and others, are publishing work in which academic and non-academic discourses are mixed. For example, many of them deliberately draw on personal experience for illustrations in their arguments, a strategy that got students labeled as cognitively deficient in Lunsford's earlier essay (a label, by the way, that I am sure Lunsford would no longer endorse - witness her recent work on the mixed or "mestiza" rhetoric of Gloria Anzaldúa, cited below). I do not want to rehearse the entire argument of my "Hybrid Academic Discourses" essay here, but let me simply point out that I conclude by asserting that to prepare students now for success in school, it may no longer be necessary to inculcate traditional academic discourse. Rather, what is needed is more help for students in experimenting with discourse forms that mix the academic and non-academic, or what I have called "hybrid" forms of aca- 
demic discourse.

Now I would like to explore some refinements of the position sketched in that essay. In particular, I now question whether the new "mixed" forms of academic discourse in which I am interested should be termed "hybrids." My first major area of critique focuses on the reified notion of academic discourse underlying the "hybrid" concept, and its function in obscuring institutional dynamics of power. In order to conceptualize the hybridization of discourse from two distinct "parents," I have provided a taxonomy of the traits of traditional academic discourse. Doing so, however, seems to suggest that traditional academic discourse was a fixed and unchanging entity until very recently. This is certainly not the case, and one does not need to go back very far to discover that fact, as I myself noted in a retrospective analysis of the ground-breaking 1971 collection The Prospect of Rhetoric (1997). I point, for example, to Alton Becker's characterization of the subject in his essay in that volume as "'man in a modern ... society,' one of whose annoyingly ubiquitous information sources is his wife" (42). This male chauvinist reference would probably be unacceptable in scholarly writing today. In short, it isn't difficult to demonstrate that academic discourse has continuously evolved over time.

Moreover, research by Michelle Hall Kells among English-Spanish bilinguals shows why it is dangerous to imply that academic discourse has not changed much over time. Such a presentation tends to give academic discourse an air of superiority that all too readily plays into linguistic minority students' tendency to see the academy's formal language as "more logical" or "purer" than their home dialects "dialect misconceptions" that lead to "linguistic shame," as Kells describes it, which impedes learning and school success (137).

It might be more accurate to say that what has remained constant is the privileged social position of whatever currently counts as academic discourse. Teachers use their own preferred linguistic standards in functioning as gatekeepers to higher education, limiting access along already established lines of class, race, and gender privilege. David Bartholomae has shown that sorting students according to their language-using practices produces a "tidy house" within the academy, seeming to distribute students according to measurable linguistic features - those seemingly obvious issues of "correctness" I noted earlier. Yet as he argues, this common practice, on which the very existence of basic writing courses is based, too often ignores or suppresses the real linguistic resources that all students bring to school. Indeed, arguments that school success depends primarily on students' ability to reproduce the currently preferred form of academic discourse divert attention from the more significant social forces that strongly influence the unequal distribution of economic opportunity and political power in this country. Elspeth Stuckey has analyzed this dynamic in adult lit- 
eracy programs in her book The Violence of Literacy, and Tom Fox has explained how it operates at the college level in his book Defending Access.

This is not to say, however, that I don't think new forms of academic discourse have begun to emerge in the last few decades. I do think changes have been happening, and I think that they may be characterized roughly in the ways that I present them in my "Hybrid Academic Discourses" essay, away from more individualistic, agonistic, and skeptical forms and toward forms more openly subjective, collaborative, and culturally diverse in allusions. The problems to which I have just been pointing aim to correct the idea that such change itself is a new phenomenon and also the related idea that school success, economic opportunity and political power are distributed solely on the basis of linguistic practices or "correctness."

At the same time, I want to note a second major area of critique of the term "hybrid" for the new kinds of academic discourse. The term is at once too abstract and too concrete. It is borrowed from postcolonial theory, and the problems with its abstraction are well analyzed in Deepika Bahri's work on applications of postcolonial theory to composition studies. I was attracted to the term "hybrid" because it upsets the dichotomy established in my earlier work between academic discourse and students' home discourses, and thus implies that discursive and cultural boundaries are more blurred and, perhaps because of that blurring, more easily crossed than had been thought in socalled current-traditional, error-hunting writing instruction. But Bahri points out:

If the concept of hybridity is useful in undoing binaries and approaching the complexities of transnationalism, as many would find in composition studies, I would warn that it also tends to avoid the question of location because it suggests a zone of nowhere-ness, and a people afloat in a weightless ether of ahistoricity. ... The scores of underclass immigrants in Anglo-America and illegal border-crossers not only cannot "make themselves comfortable" with the same ease that other postcolonials have but also know that a border-crossing can be dangerous and potentially fatal. The deeply racial and class segregated nature of our cities, moreover, should also alert us to the intransigent borders within, rather than invoking the more glamorous cultural borders that metropolitan postcolonial celebrities [such as Homi Bhabha and Salman Rushdie] invoke. (39)

Bahri's argument here also links to my earlier point about the error of assuming that social inequalities can all be attributed to different lin- 
guistic and discursive practices. I will have more to say in a moment about the need Bahri indicates to address the local and specific circumstances of our pedagogical situations.

At the same time as the concept of "hybrid" gets in trouble for being too abstract, however, it can also be critiqued for being too concrete. "Hybrid," after all, is a biological metaphor, as in such statements as, the mule is a hybrid of the donkey and the horse. Using a biological metaphor for discourse risks essentializing people's language use, as if to imply that, for example, the linguistic features of Black English Vernacular are genetically programmed into all people of African descent. I don't entirely neglect this point in my "Hybrid Academic Discourses" essay, concluding with the specific statement that "I don't think we should encourage [students] to think that each one has a unique, 'authentic-voice' sort of hybrid discourse that he or she must discover" (20). I cite bell hooks against such essentializing pedagogy, when hooks talks about her own experience in a college writing class:

Whenever I read a poem written in the particular dialect of southern black speech, the teacher and fellow students would praise me for using my "true," authentic voice, and encouraged me to develop this "voice," to write more of these poems. From the onset this troubled me. Such comments seemed to mask racial biases about what my authentic voice would or should be.... I had come to understand black poets as being capable of speaking in many voices, that the Dunbar of a poem written in dialect was no more or less authentic than the Dunbar writing a sonnet. Yet it was listening to black musicians like Duke Ellington, Louis Armstrong, and later John Coltrane that impressed upon [my] consciousness a sense of versatility they played all kinds of music, had multiple voices. So it was with poetry. (quoted in Bizzell 1999, 20)

And so it is with academic discourse, as bell hooks' own scholarly writing demonstrates.

There is a larger problem here, however, and that is the nature of the variant forms that are coming into academic discourse such as hooks'. The biological metaphor of hybridity implies that what mixes in the new forms, as I noted earlier, are two distinct "parents," that is, distinct, well defined and culturally independent linguistic and discursive practices. It is not at all clear that this is the case, however. It may be possible to trace certain locutions in bell hooks' work to Black English Vernacular, which is a distinct dialect of English; and in looking at Victor Villanueva's work, we can notice which words are English and which are Spanish. It is not so easy, on the other hand, to 
trace to Puerto Rican culture some of the discursive features that I identify in his work. Is "offhand refutation" or "appropriative history" distinctly Latino (14)? This would be hard to prove. Similarly, when Andrea Lunsford discusses "mestiza rhetoric" with Gloria Anzaldúa (1998), it appears that while some features of Anzaldúa's prose may be traced to her racially and linguistically mixed background, other features can be identified no more precisely than to note that they are not traditional in academic discourse or that they are familiar from other writing by women.

In short, what is crucially left out of my "Hybrid Academic Discourses" analysis is the profound cultural mixing that has already occurred in the United States. Even students who are the first members of their families or their communities to attend college come with already mixed linguistic and discursive resources, as Scott Lyons explains in discussing the narratives of American Indian students:

To my mixedblood mind, the stories of Indian students are clearly heteroglossic - produced against, within, and in tandem with the grand narratives of contemporary American life and culture ... . There is a European in every Indian and an Indian in every "white" - each relationship positioned differently and the two are not together by choice. It is this kind of contact heteroglossia that has been repressed by educators and theorists for centuries, and that Indian students not only know, but also use daily - we can all learn from them in this respect. (88-89, emphasis in original)

Lyons argues forcefully for the need for Indian students to use Indian discursive resources in their college writing, but at the same time, he shows how very difficult it would be to tease out the Indian strands in academic writing that nevertheless may be clearly recognized as "nontraditional," variant or new.

Moreover, Lyons points in passing to another important aspect of mixing that many of us have experienced in our classrooms today, and that is the "contact heteroglossia," to use his term, that can be seen in the writing of European American students. Basic writing teachers know that it is a mistake to expect something like traditional academic discourse from all the students who appear racially white or who selfidentify as white. Experimentation with new discourse forms certainly cannot be attributed to any essentialized linguistic heritage in the case of these students, although I may have misleadingly implied that new forms of academic discourse have emerged mainly because "more people who are not white males of the upper social classes are gaining access to post-secondary education and to positions as post-secondary teachers and scholars" (11). Yes, increased access has happened, and a 
wide range of published scholarship employs new forms of academic discourse, as I have noted, but it is misleading to imply that new forms have emerged simply to make new students and scholars feel more comfortable. The new forms are being used by everyone, not only by students and scholars from under-represented social groups, and the reason is not far to seek. I should have emphasized this point more strongly:

Perhaps these new discourses are gaining ground, too, because they enable new kinds of intellectual work. I want to emphasize that I see these hybrid forms not simply as more comfortable or more congenial but as allowing their practitioners to do intellectual work in ways they could not if confined to traditional academic discourse.... These hybrid discourses enable scholarship to take account of new variables, to explore new methods, and to communicate findings in new venues, including broader reading publics than the academic. (11-12)

What I describe here, after all, should be a major reason why academic discourse continually evolves, as I argued earlier that it does.

A major question remaining is how composition pedagogy should evolve in turn. On this head I want to return to Bahri's point, reinforced also by Lyons and Kells, that successful pedagogies must take local circumstances into account. Here, I recommend engaging students in reading and writing about "a cultural crux of our day" that is "carefully derived from local conditions" (17). This approach would engage students in studying and producing texts from what Mary Louise Pratt calls a "contact zone," the very antithesis of the "zone of nowhere-ness" against which Bahri inveighs, and the source of what Lyons terms "contact heteroglossia." Pratt describes the "contact zone" this way:

I use this term to refer to social spaces where cultures meet, clash, and grapple with each other, often in contexts of highly asymmetrical relations of power, such as colonialism, slavery, or their aftermaths as they are lived out in many parts of the world today. (34)

Using this concept to suggest directions for composition pedagogy would not, presumably, lead us to ignore the structural inequalities to which Bahri points in her critique of the concept of border-crossing, since Pratt highlights "asymmetrical relations of power" and their influence on discursive practices. For suggestions on how to develop such pedagogical materials, see my "Hybrid Academic Discourses" essay, or my earlier piece on contact zones. Also, Bruce Herzberg and 
I have co-authored a textbook, Negotiating Difference, which collects materials from American contact zones. Of course, it should be said that I somewhat contradict my own principles by publishing such a book. For pedagogical materials to be truly local, they probably should be developed on site, and in collaboration with the students one has in front of one in any particular semester. But I am hoping that some teachers will luckily find in this textbook materials relevant to their own local situations. An important point to be made here, however, is that if basic writing pedagogy is to shift to fostering variant forms of academic discourse, I believe that we will still be obliged to try to encourage these variant forms to be done well. If traditional "correctness" is no longer the issue, student skill and application still will be important.

One further point on which I could perhaps be questioned is my avowed aim to help students succeed in school, a perennial goal of basic writing instruction that, I believe, we would do well to retain. One could argue that this is merely a reformist, and not a revolutionary, goal, and hence will do little to correct the glaring social inequalities that should gall the heart of anyone committed to the ideals of American democracy. If newly evolved composition pedagogies help to democratize access to the academy, however, their ultimate consequences might be more far-reaching. Democratizing access may help along the changes in academic discourse described in this essay, thereby serving social justice - or at least, so I may be allowed to hope.

\section{Works Cited}

Bahri, Deepika. "Terms of Engagement: Postcolonialism, Transnationalism, and Composition Studies." JAC: A Journal of Composition Theory 18 (1998): 29-44.

Bartholomae, David. "The Tidy House: Basic Writing in the American Curriculum." Journal of Basic Writing 12 (Spring 1993): 4-21.

Bizzell, Patricia. "Contact Zones and English Studies." College English 56 (1994): 163-69.

- - - "Hybrid Academic Discourses: What, Why, How." Composition Studies 27 (Fall 1999): 7-21.

- - - "The Prospect of Rhetorical Agency." In Making and Unmaking the Prospects for Rhetoric. Theresa Enos, ed. Mahwah, New Jersey: Lawrence Erlbaum Associates, Inc., 1997.

- - - "What Happens When Basic Writers Come to College?" College Composition and Communication 37 (October 1986): 294-301.

- - - , and Bruce Herzberg. Negotiating Difference: Cultural Case Studies for Composition. Boston: Bedford Books, 1996. 
Fox, Tom. Defending Access: A Critique of Standards in Higher Education. Portsmouth, New Hampshire: Heinemann-Boynton/Cook, 1999.

Kells, Michelle Hall. "Leveling the Linguistic Playing Field in FirstYear Composition." In Attending to the Margins: Writing, Researching, and Teaching on the Front Lines. Portsmouth, New Hampshire: Heinemann-Boynton/Cook, 1999.

Lunsford, Andrea. "The Content of Basic Writers' Essays." College Composition and Communication 31 (October 1980): 278-290.

- - - - , and Gloria Anzaldúa. "Toward a Mestiza Rhetoric: Gloria Anzaldúa on Composition and Postcoloniality." JAC: A Journal of Composition Theory 18 (1998): 1-27.

Lyons, Scott. "A Captivity Narrative: Indians, Mixedbloods, and 'White' Academe." In Outbursts in Academe: Multiculturalism and Other Sources of Conflict. Kathleen Dixon, ed. Portsmouth, New Hampshire: Heinemann-Boynton/Cook, 1998.

Pratt, Mary Louise. "Arts of the Contact Zone." Profession 91 (1991): 33-40.

Stuckey, J. Elspeth. The Violence of Literacy. Portsmouth, New Hampshire: Heinemann-Boynton/Cook, 1991. 


\title{
Terence Collins and Melissa Blum
}

\section{MEANNESS AND FAILURE: SANCTIONING BASIC WRITERS}

\begin{abstract}
This article considers the systemic attack on economically impoverished students in higher education. The locus of consideration is a group of students enrolled in the University of Minnesota General College under a pilot welfare reform program. Terminated abruptly for political reasons, the project failed, with impacts on the student-parent participants. The authors' face-to-face relationship with the students is the basis for reflection on the broader issue of access.
\end{abstract}

We fear that the focus of this set of essays - the "state of Basic Writing"--may be alarmingly beside the point. Three decades into the enterprise, the basic writing community knows a great deal about how to teach writing among students who are unpracticed in the creation of extended prose texts and unschooled in the ways of academic discourse. When basic writing teachers have reasonable training, reasonable teaching loads, and reasonable support, they can do fine work, and may be observed doing so in a range of sites around the country. We have plenty of insightful work on how good basic writing curricula shape the abilities and life prospects of diverse students. To be sure, we have disagreements about the role of basic writing in the curriculum, about how we represent our students, and about the wisdom or ethics of how we name the work we do. But as a profession, we know a lot about the competing varieties of what to teach and have access to good models for how to do it.

In this brief piece, we'd like to focus not so much on the state of basic writing as on the state of access to higher education among disenfranchised students. In this we are hardly original or alone. In the last half-dozen years, in fact, wonderful books have treated the sub-

Terence Collins is Morse-Alumni Distinguished Teaching Professor in General College, where he is also Director of Academic Affairs and Curriculum. He was co-author and Principal Investigator for the FIPSE grant which helped support the pilot program described here. He teaches Basic Writing and literature. He has written on Basic Writing, Disability Studies, and Technology.

Melissa Blum is a Ph.D Candidate in English at the University of Minnesota. She has taught Basic Writing at General College for six years, including the writing section for the Student Parent MFIP Program described in this article. She also directed an "autoethnography" video project with the MFIP students, who chose to use this video as a forum to tell policy makers and educators about the stories and political realities of their lives. 
ject-we'd recommend as a good starting list Marilyn Sternglass's Time to Know Them, Tom Fox's Defending Access, and Lavin \& Hyllegard's Changing the Odds: Open Admissions and the Life Chances of the Disadvantaged. What we exploit, perhaps in counterpoint to the optimistic fine work of others, is a local failure of the authors' own making. We offer this portrait of our failure and the resulting consequences for the economically impoverished women we sought to teach as a basis for reflection on the very tangible limits of what basic writing programs can hope to do when access to higher education is stripped from students whose life circumstances are socially and economically vexed. In doing so, we hope to add a sense of urgency regarding the question of access to higher education among populations traditionally served by basic writing programs. We can't see ourselves responding very intelligibly to the JBWeditors' call for thoughts on the state of basic writing without first considering our very visceral recent struggle with the state of basic writers and their increasing erasure from higher education.

Here's our story. In 1996, as a result of changes in federal laws, Minnesota passed so-called welfare reform legislation, to be effective in 1997, replacing the established program of Aid to Families with Dependent Children. Under Minnesota's version of this national initiative (the "Minnesota Family Investment Program" - MFIP), welfare clients were placed under severe limits on access to benefits. The new MFIP rules provided for a lifetime maximum of five years of support, health coverage, limited child care benefits during job preparation and work, and the opportunity to engage in supported job training for up to a year (two years with case manager approval) while transitioning into employment. Like its counterpart programs in most states, MFIP's rules were aimed at rapid transition to work among the targeted welfare clients, nearly all of whom are single-parent women. While not stated explicitly, the clear goal of the new welfare programs like MFIP is rapid movement into low-skill entry level employment for single mothers. Implemented in local variations by all states in 1998, the new welfare laws reconfigure patterns of the social contract in ways that create new obstacles for access to higher education among some of the most disenfranchised citizens. (Some states, such as Maine, have been more thoughtful in building access to four-year higher education into the welfare reform mix.)

At the University of Minnesota, we and our colleagues approached new welfare legislation with some optimism about higher education's possible role. For twenty-five years, General College has served student-parents with special child-care and counseling programs through its HELP Center (Higher Education for Low-Income Persons). Until 1997, we held contracts with several local counties to provide higher education for welfare recipients under the former Aid to Families with Dependent Children welfare program, supplemented 
by child-care grants from local corporations and foundations. Prior to 1997, hundreds of women receiving welfare benefits had entered the University of Minnesota through this program, earning degrees and becoming self-supporting in well-paying jobs.

In view of the HELP Center's successful experience under former welfare laws, a mixed group of University academic advisors (one of them an alumna client of the program), faculty, and administrators sought ways to provide meaningful access to higher education for impoverished women under new MFIP legislation. The group contained seasoned HELP Center advocates for student-parents, a widely published and nationally respected family economist with an academic interest in welfare reform, basic writing teachers and other faculty, the General College's academic affairs director, financial aid counselors, and student employment personnel. The group represented a wide range of attitudes toward welfare reform, from radical hostility to MFIP to centrist openness to options that might reduce women's dependency on government welfare programs.

While we approached the question of welfare reform from a number of points on the political compass, we had in common an understanding of and commitment to the capacity of higher education to contribute to the long-term material well-being of women and their children living in poverty. We knew that family median income among households in which an adult has a baccalaureate degree is $175 \%$ of that in a household in which the adult has only a high school education. We knew that fast training and entry-level jobs under so-called "workfare" had produced neither living wages nor sustained employment among former welfare recipients in a neighboring state whose experiment with "workfare" predated the national mandate for welfare reform. We knew from census data that baccalaureate education of the parent in a household maps onto all sorts of quality-of-life indicators, most of them dear to the hearts of welfare-reform and familyvalues advocates: higher family income; higher educational attainment among children in the family; increased percent of life spent economically independent; higher rates of employment; increased work-life expectancy of children; better health; higher rates of home ownership; better access to health insurance; increased participation in citizenship functions such as voting; higher rates of volunteerism; lower incidence of incarceration, lower rates of participation in government assistance/ welfare programs; and lower "out-of-wedlock" birth rates. In short, we knew that traditional baccalaureate education provided a framework for realizing the core goals of welfare reform: economic and personal autonomy with demonstrable intergenerational impacts. ${ }^{2}$

The program we proposed was surprisingly simple. Women who elected to participate and who were approved by their case managers for inclusion would be supported by MFIP in their first two years of 
enrollment in the University. With child-care support, they would use the maximum training period allowed by MFIP law, transitioning during the second year to student employment at twenty to thirty hours per week to meet state requirements. During the first year, in addition to a normal academic pre-major program, participants would engage in a series of non-credit job-preparation sessions taught by counselors and more experienced peers on a range of subjects, from time management to workplace conventions to computer skills and the like, in preparation for campus employment. Student jobs, ranging from parking attendant to lab assistant, pay significantly better than do typical entry-level retail and light manufacturing jobs in the area, a feature of the program which led the students' case managers in the community to see it positively. Following their transition year, student participants would essentially work their way through college via student employment and financial aid or full-time civil service employment with tuition benefits, as do thousands of their non-MFIP peers, while maintaining child-care and health benefits under normal MFIP procedures.

In setting out to include baccalaureate education as an option under new welfare reform legislation, we were neither naïve nor particularly hubristic. The HELP Center had successfully offered assistance to a generation of women who came to the University as single parents in poverty. We knew how to do this. Legal Aid attorneys advised us that we were within the new welfare reform law in constructing the program. The U.S. Department of Education's Fund for the Improvement of Post-Secondary Education (FIPSE) concurred that this was an idea worth testing, providing what was to have been a three year grant for start-up and research costs. And the administrators of MFIP at the state level gave a reluctant go-ahead for the pilot program.

Because we knew we were launching a fishbowl program in which any failure might be used to exclude from consideration future proposals for baccalaureate education under MFIP, we sought to keep the initial pilot program small and well-controlled, with a pilot group of twelve women and a target of adding just fifty new students each year. Participants were selected only with the concurrence of their county case managers and only as part of a negotiated long-term plan to become independent from welfare.

But in the autumn of 1998, just as we were finishing identification of our pilot group for enrollment, Minnesota's political climate changed markedly. Fueled by young first-time voters and disgruntled working-class voters, a former show-wrestler and talk-radio personality was elected governor on the Reform Party, defeating heretofore popular traditional liberal Hubert Humphrey II. Equally important, fuelled by the backlash vote that elected the new governor, control of 
the Minnesota House of Representatives shifted toward a more conservative base under a new Republican majority. The incoming governor made it clear in a televised confrontation with students that the state would not "pay for the mistakes" of single mothers seeking college education, and key committee chairs in the House were now occupied by conservative supporters of a strict interpretation of welfare reform. Six weeks into the first academic term for our participants, permission to pursue the pilot program was rescinded by the state. Despite a welfare budget surplus of over $\$ 160,000,000$ and a general budget surplus of over $\$ 2,000,000,000$ (a lot of money in a relatively small state like Minnesota), counties were forbidden to place any new students into the program, and those already in the program were ordered to quit. Program staff, students, and community allies fought the ruling. Although several students in the pilot program successfully sued the state and received a temporary injunction barring their termination from the program, no new MFIP students would be enrolled. Faced with the prospect of having no clients, we resigned the FIPSE grant in the second year. It is likely that current students from the pilot will be "sanctioned" (lose some or all of MFIP funding and non-cash supports) if they continue in the University. They will have used up their training time and incurred debt without the opportunity to complete their education with even reduced MFIP support. In Minnesota, at least for the time being, welfare recipients have been erased from four year higher education. We failed them.

Because all students who enter the University of Minnesota through General College enroll in the two semester basic writing sequence, we used a section of that course as one of the common "cohort" elements of the pilot program. In retrospect, it is fortunate that we did so, because in the students' writing we were able to capture a sense of the participants' aspirations for themselves and their children. Moreover, as the program began to come apart, we were able to see in the students' writing and in a related video project the hope they felt upon their initial enrollment and the pain they feel at their impending exclusion from the privileged/privileging world of the University. One of the women wrote, as part of her basic writing course's first assignment:

My son and I are walking up to the welfare department. My son is at my side, his mittens keep falling off, so we have to keep pushing them back on. His nose is red and we are both really cold. There is a man standing outside smoking a cigarette. He turns to my son and says, "what is up little man?" My little boy says, "food stamps." I kind of smile to myself, because my son really doesn't know what that means, he just knows that he gets to go to the store and buy some ice cream.

We walk into the lobby, sit down, and wait for our num- 
ber to be called, I show up extra early, hoping that they will see that welfare recipients can be responsible, deep down I know that doesn't really matter, because they already have preconceived notions about welfare recipients. We are lazy and just don't want to work....

I am nervous today, because I am going to ask for an education. This is not the first time I have asked for one. The workers there all respond the same way, they tell me "you are too old, or that just isn't part of our program." Today I am ready; I have all the information they need and all the possible arguments played out in my head. Finally my number has been called, and my son and I walk back to a little cubical. My worker begins by telling me that I have been sanctioned for that month and I won't receive any money. I asked, "why am I being sanctioned?" She then explains to me that I didn't have the necessary paper in that month. That is when I realized that she had someone else's file and not mine.

My worker pulls out a list of jobs for me that pay an average of six dollars an hour, I explain to her that a single parent cannot adequately provide for their children on six dollars an hour, and what I really need is an education. My worker takes a deep breath and rolls her eyes....

That week I began working for the welfare department, they put me at the front desk stuffing envelopes and talking with the welfare recipients as they come in the door. During those weeks of working there I counted only a few women who didn't show visible signs of domestic abuse, I watched the workers tell those women who had just been beaten the night before that they have to get a job and that caring for their children is just not enough....

When I began at the University, I was very nervous. I found comfort in the other women and the staff was very supportive. I would like to receive a degree in Early Childhood Family Education. When getting a degree I would be setting a good example for my son to follow and it would better prepare me to help him to go on and get a higher education someday as well.

The staff at the University still fights each day with the legislation and the welfare department to keep the program going. I feel very fortunate to be here and I truly hope the program remains for many more women needing and wanting to continue their education. I am hopeful as well that someday people will begin to understand that the only way out of poverty is with a good education [sic]. 
As a child, I was always told that education is very important, yet no one provided me with the tools needed to be successful in an educational environment. One reason is because my home life has always been dysfunctional. My parents (although separated) were both addicted to crack-cocaine, so there was very little emphasis on homework and studying. I eventually learned that school was important and why. Between the ages of six and ten, I used school as a safety net. I wanted to go to school to get away from all the crap that was going on at home. It was during this time that I learned that [a degree] could free me from the oppression that my family endured because of a lack of education.

As I entered my teenage years, my parents' addiction worsened, making it increasingly hard to pursue my education. By this time, I had three younger siblings for whom I was responsible. I began missing classes so that I could send my brothers to school and care for my baby sister. Within months, I was not attending school at all. I stayed hopeful and tried to keep up with my school assignments on my own. Unfortunately, the school I attended automatically failed students who miss ten days of class.

I decided that if I was going to get an education, it would have to be on my own terms, and the only way to achieve this would be to get married. At the time, I didn't realize that getting married would take me a step further from reaching my educational goals, the reality is, when you are on your own you have to support yourself. I spent the next five years working at White Castle instead of working on a degree.

So here I am with one month's experience in a university, I hope to be a lawyer.... I am still considerably overwhelmed, but I know that I am in the right place. Everyday I am learning new things. Each time the sun rises and sets, I look at it in different ways, I have learned that there is more than one way to solve a problem. I learned to analyze ideas. I have gained emotional self-sufficiency. Even if this program were to end tomorrow, no one can erase the knowledge I have acquired thus far. I will carry it with me forever. Most importantly, I will pass all that I learn on to my children and always stress the importance of education [sic].

In the end, we marvel at the students. They understand the ways in which their lives are contextual, the ways their lives intertwine with the machinery of the institutions they encounter. They understand 
themselves in relation to their poverty and in relation to the convergence of social forces which construct their poverty. They are more than good Freireians. They are promising writers. They are good mothers, and, if they'd been given the chance, they would have been good students and good employees.

Our depressing experience constitutes a sample, at best, of the dynamics of exclusion at work in higher education. Statistics tell part of the story: low-income people continue to be far less likely to attend college than their middle-income and high-income peers (Choy). ${ }^{3}$ Press coverage of the CUNY crisis makes the politics of access visible, and occasional articles in The Chronicle of Higher Education or The Nation focus our attention on the larger landscape of access (see such recent articles as Alan Jenkins' "Leveling the Playing Field: An Opportunity Agenda" in the The Nation and Joel Hardi's "State and Federal Governments Urged to Improve Training of Welfare Recipients" in the Chronicle). But because we know these women, because we recruited them, because we got to know their children, and because we worked with them over the last year as writers and video-makers, the dynamic of their exclusion has a real face. We're denied the comfort of abstract arguments and numbers in this instance. Erasure of impoverished women from higher education under the banner of welfare reform is no longer for us part of an abstract argument about access or about representing the "other" in our construction of basic writing. For us, it's become twelve distinct people with aspirations, children, sweet writing voices, and no place in our university.

The state of basic writing? Elegant, from where we sit, in unimaginable ways. But the writers are being disappeared.

\section{Notes}

1. The project described here was supported in part by a grant from the Fund for Improvement of Postsecondary Education of the U.S. Department of Education, for which we are very grateful. Additional funding for student writing and video projects came from the University of Minnesota Center for Interdisciplinary Studies of Writing and the University of Minnesota-Coca Cola Community Partnership.

2.All the information given in this paragraph can be found in a single article: "Private Correlates of Educational Attainment" in the Postsecondary Educational Opportunity newsletter. It's worth adding this newsletter's email <tmort@blue.weeg.uiowa.edu > because this is such a rich monthly source that too few people use.

3. The specific citation here is a small part of a treasure trove of educa- 
tional statistics from the National Center for Educational Statistics website: http://nces.ed.gov.

\section{Works Cited}

Choy, Susan P. "The Condition of Education 1998 / Issues in Focus: College Access and Affordability." National Center for Educational Statistics, http://nces.ed.gov/pubs98/condition98/c98005.html.

Fox , Tom. Defending Access: A Critique of Standards in Higher Education. Portsmouth, NH : Boynton/Cook Publishers-Heinemann, 1999.

Hardi, Joel. "State and Federal Governments Urged to Improve Training of Welfare Recipients." Chronicle of Higher Education, February 18, 2000: A44.

Jenkins, Alan. "Leveling the Playing Field: An Opportunity Agenda." The Nation, March 6, 2000: 16-20.

Lavin, David E. and David Hyllegard's Changing the Odds: Open Admissions and the Life Chances of the Disadvantaged. New Haven:Yale University Press, 1996.

"Private Correlates of Educational Attainment." Postsecondary Educational Opportunity: The Mortenson Research Seminar on Public Policy Analysis of Opportunity for Postsecondary Education 61 ( July 1997): 1-17.

Sternglass, Marilyn S. Time to Know Them: A Longitudinal Study of Writing and Learning at the College Level. Mahwah, NJ: Erlbaum, 1997. 


\title{
William DeGenaro and Edward M. White
}

\section{GOING AROUND IN CIRCLES: METHODOLOGICAL ISSUES IN BASIC WRITING RESEARCH}

\begin{abstract}
Basic Writing has failed to distinguish itself as a mature field of study since the researchers in the field do not seem to listen much to each other or to build on each others' findings. While those working in developmental writing demonstrate, for the most part, ideological agreement, we have significant conflict over what counts as valid evidence by which to build and advance knowledge. An analysis of methodologies used by those embroiled in the "mainstreaming debate" illustrates this methodological confusion, which leads to monologues going around in circles rather than constructive dialectic. While methodological conformity would be undesirable, researchers ought to consider the evidence and arguments of those using a variety of approaches to research.
\end{abstract}

Mature fields of study have developed forms of progress, ways of developing knowledge. For example, as researchers in chemistry, biology, or cosmology publish findings, the fields find ways of debating their soundness and coming to consensus about them. Thus, while the nature of the Big Bang, or its causes, or what if anything existed before it can still be discussed, astronomers no longer need debate whether it occurred or when; they can move on. And once we know that the planets revolve about the sun, we can move on to further exploration of the cosmos. Now, to be sure, there are segments of the population for whom these matters have not been settled and never will be. But these are people outside the scientific community for whom matters of ideology, personal experience, or special forms of reasoning disallow the professional consensus. Those for whom experience is the touchstone will believe in their hearts that the sun goes around the earth, for they see that happen every day. Nonetheless, this resistance to developed knowledge in the sciences, however popular in some quarters, has little effect on professionals in their laboratories. We can say the same about other mature fields of study. The Shakespeare au-

William DeGenaro is pursuing a doctorate in the Rhetoric, Composition, and the Teaching of English program at the University of A rizona. His primary interests include the history of the two-year college, working-class literature, and the theory and pedagogy of basic writing.

Edward M. White is author or editor of nine books on uriting and writing assessment, most prominently Teaching and Assessing Writing, 2nd ed., 1994. He is a professor emeritus at California State University, San Bernardino, and an adjunct professor at the University of Arizona. 
thorship controversy is a joke to specialists in the Renaissance.

Perhaps the best parallel to these matters in the field of composition studies has to do with the role of formal grammar study as a means of helping students improve their writing. Since the research team headed by Richard Braddock in 1963 declared the study of formal grammar to be useless or worse for writing instruction, their findings have been repeatedly affirmed, as Hillocks demonstrated in 1986. The definitive article on the matter by Patrick Hartwell in 1985 built on the many studies of grammar and contributed a theoretical framework to the findings. By now, the strong professional consensus about the peripheral place of formal grammar instruction in the teaching of writing is beyond dispute, as almost all contemporary writing textbooks make clear.

As with findings in other fields of study, we do have many for whom this professional consensus on the role of grammar is meaningless or wrong. Some teachers dismiss the consensus in the light of their personal experience: "I don't care what the research says; my students learn to write because I teach them grammar first." Others will argue syllogistically: "you can't write paragraphs until you have learned to write grammatical sentences." Still others will base their arguments on ideology, which negates all the evidence: "grammar is the basis on which all language is built, so students must learn grammar before they can begin to write." While such teachers are more prevalent than Biblical fundamentalists in biology, they also remain on the fringes of the profession, whose knowledge-makers can pretty much ignore them and move on, seeking ways to help students write more grammatically without the useless study of formal grammar.

But it is hard to come up with other examples of professional consensus on matters in Basic Writing, since the researchers in the field do not seem to listen much to each other or to build on each others' findings. In this article, we are defining progress in our field as the development of professional consensus about key issues: findings or premises are published, debated and tested over time, and certain matters are, as a result of the professional dialectic, considered settled. As with the grammar issue, after some hundreds of studies have reached the same conclusions and a theoretical base has been established, we do not have to continue to test the same hypotheses; we can move on. Unhappily, on some of the most crucial matters in Basic Writing, this is not the case. Instead of moving toward a consensus, our researchers too often talk past each other, positions are reiterated rather than reconsidered, and we move in circles. We intend here to look closely at one line of research that exemplifies this and then to offer some suggestions to the field that might straighten out these circles and support our claims to an orderly, or at least an identifiable, discipline: Basic Writing Studies. The advantages to professional consen- 
sus are legion, not the least of which is that we can better capitalize on our ideological agreement about the importance of helping the least prepared of our nation's college students succeed.

\section{The Problem of Placing Entering College Students}

The problem of placing students into a basic writing curriculum - whether it is or is not the best way to help underprepared students succeed - lies at the heart of basic writing issues and so is an appropriate issue for this study. The problem is researchable from a variety of perspectives, opens into most of the other central concerns in basic writing (such as whether there should be a writing requirement and, if so, what should be the appropriate curriculum), and should be subject to a gradual increase in knowledge as research accumulates. Unfortunately, it is a better example of writing research going around in circles.

Few issues have sparked as much emotional debate in the pages of the Journal of Basic Writing as the question of whether colleges and universities should "mainstream" developmental writers into the standard, first-year writing course. Those who support mainstreaming believe higher education should cease and desist the sorting and placing of students and make schools more egalitarian spheres. By maintaining systems of remediation, the pro-mainstreaming faction argues, writing programs perpetuate a hierarchy of dialects and linguistic differences. Meanwhile, those opposed to the mainstreaming of basic writers believe that basic writing courses serve the most underprepared writers on campus. Without basic writing, this camp suggests, a diverse student body would be less prepared to succeed in college and beyond. Although the debates between those who support mainstreaming and those who oppose it have grown increasingly divisive, it is evident that both factions want to democratize higher education.

Those embroiled in this debate represent an essentially homogeneous set of political beliefs. They demonstrate an acute awareness of the historically elite role higher education has played in American culture, and want to take proactive steps to combat the trend. Howard Tinberg, arguing in favor of basic writing, writes, "[W]e must come to the realization that if the students whom we admit to our colleges lack basic reading and writing skills, we have a moral and ethical obligation to those students to give them what it takes to succeed in college" (88). Tinberg clearly values that colleges have become increasingly accessible, less elite places. Ira Shor writes with even greater passion about the egalitarian goals institutions of higher education ought to enact as well as declaim. Arguing contrary to Tinberg and calling for the abolition of developmental writing, Shor declares that we should 
be "serious about democratic education in a democratic society" (99100). Tinberg and Shor find themselves, despite ideological agreement, on opposite sides of this important and ongoing debate about the effects of placement.

While controversy and debate are generally healthy ways to stimulate thought and advance knowledge production, the subfield of Basic Writing frequently finds itself needing to present a unified front to administrators, politicians, and policy makers who do not share the belief that institutions of higher education should be diverse and democratic. Basic Writing is a particularly, even uniquely, public wing of English studies. Frequently, those in charge of basic writing programs and curricula need to defend their very existence to audiences beyond their professional peers. When conservative lawmakers convinced the Board of Trustees at the City University of New York (CUNY) to end all "remedial" coursework at its senior colleges in 1998, they capitalized on the dissension in the ranks of basic writing scholars and practitioners, quoting abolitionist arguments from our professional literature. This is not to say we think this particular conversation should end. Nor are we calling for a reductive, "can't we all just get along?" resolution. The subfield of Basic Writing needs to examine more closely the nature of our disagreement. A more critical "meta awareness" of our methodology could help us build consensus and work toward our common ideological goal, what Mike Rose calls "education for all members of a vast pluralistic democracy" (238).

\section{Writing Placement and the "Universal Requirement"}

A particularly instructive example of the way in which we have failed to reach the methodological consensus of which Rose speaks is the debate over what Sharon Crowley has called "the universal requirement." In her provocative book Composition in the University and elsewhere, Crowley puts forth a "modest proposal" to abolish requiring first-year college students to take composition (Composition 240). Robert J. Connors has shown how advocates for the abolition of required first-year composition surface every few decades, "when some teachers declare it too hopeless to reform" (47). Essentially, Crowley problematizes both the ability of the academy to know what students need and the ethical implications of a mandate that perpetuates and facilitates poor labor practices. John Ramage last year critiqued Crowley's methodology, stating, "Abolitionists offer suggestive but hardly definitive evidence for universal problems of hyperbolic proportions, buttressed by chilling anecdotes and pithy quotes" (online). Notice that Ramage takes Crowley to task not on ideological grounds but methodological ones. To be sure, most compositionists share 
Crowley's egalitarian goals: Who among us would deny the need to attend to institutional labor practices? But we have strong divisions about what might constitute valid evidence, that is, a "definitive" research methodology that could advance these goals.

Ramage's critique, rather, gets at the lack of consensus about how to generate knowledge about this issue. He argues that the unconvincing evidence provided by the New Abolitionists consists only of hyperbole, anecdote, and quotations out of context. While reductive for rhetorical effect, this complaint might be restated in terms that Stephen North would recognize as a combination of what he calls "practitioner" and "philosophic" research. That is, the abolitionists advance their conclusions by argument from first premises and classroom experience, without attempting to reach generalizations through the more usual routes such as experimental data. We might extend Ramage's argument by pointing out that the methodologies used by the New Abolitionists are precisely those not adapted for gaining consensus but rather for stimulating dialectic, argument, and impassioned debate. In other words, in order to convince us that the conclusions we have been hearing from the New Abolitionists are sound, Ramage seems to be saying, we need a different kind of evidence, "definitive" evidence, or, as we would put it, experimental data. In fact, at the same conference where Ramage debated Crowley (The Western States Composition Conference), another member of the same English department attempted to present such data, the results of a systematic survey of student satisfaction with their experience in the required first year courses of the writing program. The data showed that a very high percentage of the students surveyed actually valued their required composition course. The data were entirely ignored as the discussion proceeded, and one of the Teaching Assistants declared that the required writing course was one that teachers hated to teach and students hated to take. It appeared then and appears in general that the methodology of the New Abolitionists is not interested in data or surveys - the "definitive" evidence produced by what North and others call "experimental" methodologies. To ignore data that contradicts one's doctrines seems short-sighted. But we can only say this if we trust and value evidence produced by an experimental methodology.

Crowley lacks empirical data, as does her fellow New Abolitionist Peter Elbow. This is not to accuse either of lack of scholarly rigor per se, but rather to point out their methodological orientation, which leans toward philosophical dialectic and anecdote. Philosophical dialectic is useful for advancing the conversation and integrating multiple voices into the debate and narrative has a unique rhetorical ability to persuade through emotion. Crowley and Elbow have suggested, respectively, provocative implications of the universal requirement and the assessment measures which support the requirement. However, 
as a methodology, philosophical inquiry lacks the kinds of data that experimental methodology boasts. One of us, White, responded to Crowley's call for proof that the requirement helps students. His article in the Journal of Basic Writing was a direct response to that challenge, using both argument and experimental data. Crowley in turn responded to that article with a letter published the following year. When we look closely at that exchange, we can see a clear example of the ideological consensus; both mentioned the value of protecting access to higher education and helping less-prepared students succeed. But just as clearly that exchange demonstrates a fundamental disagreement over what counts as valid evidence and hence the lack of productive dialectic between the two researchers. When White asked Crowley, also at the Western States Composition Conference, why she had not responded to his article, she replied that her letter had done so. White in turn said that she had ignored his article in her letter. What could account for such a different view of the Journal of Basic Writing exchange?

\section{Methodologies at Work}

The inability to communicate effectively, that is to say in a way that advances our knowledge of issues of developmental writing, is not limited to the Crowley-White exchange. An examination of the scholarship concerning the "mainstreaming" debate within the Journal of Basic Writing in recent years reveals the presence of multiple and competing methodologies at work. Though it is not uncommon for different researchers to approach an issue using various modes of inquiry, it is imperative that we build consensus in order to appeal effectively to audiences outside our immediate discourse community. At the risk of hyperbole, higher education's ability to serve the populations that fill our developmental classrooms depends on the identification of methodological common ground. In the remainder of this article, we examine some representative scholarship on mainstreaming in the hopes of building methodological meta-awareness, which we consider the first step toward making informed and collective decisions about how best to advance knowledge in our field.

It is evident that the field of basic writing trusts the validity of experimental research to varying degrees. Perhaps this should not be surprising, given the problematics of identifying meaningful variables and interpreting experimental data. Further, opponents of experimentalism have long pointed out that the methodology has its roots "in formulations designed to deal with corn yield per acre," a far stretch from testing the efficacy of developmental writing courses and programs (North 141). Still, experimental research, on the surface at least, 
appears to be the most appropriate methodology for inquiry into the mainstreaming of basic writers. As Stephen North points out in his still relevant text The Making of Knowledge in Composition: Portrait of an Emerging Field, experimentalism has historically been useful for testing the success level of various pedagogies, from formal grammar instruction to sentence combining to various teacher commentary styles (143-4). But empirical studies that suggest the benefits of basic writing have been met with mixed reactions.

There is likewise little agreement over the validity of "practitioner research," a dominant mode of inquiry in the pages of the Journal of Basic Writing. Concerning the issue of mainstreaming, the temptation, of course, is to come to grand conclusions based on anecdotes emerging from our basic writing classes. No doubt, for all of us, our immediate reaction to the mainstreaming issue is rooted in our classroom experience. My students mean so much to me that I would never dream of doing away with basic writing courses. Or: I've observed students improve during the semester. We work in a knowledge-building community that consciously seeks to acknowledge the classroom as a meaningful and scholarly domain, but we risk sacrificing rigor and validity when we fail to interrogate what we mean by "evidence."

In his 1995 article, "The Importance of Placement and Basic Studies: Helping Students Succeed Under the New Elitism," one of us, White, uses experimental research to argue in favor of both basic writing and the large-scale assessment measures that place students there. White's evidence suggests that basic studies and placement measures assist students who otherwise might not remain in college. He seeks to counter "both well-meaning academics and less well-intentioned legislatures and governing boards" who support abolition (76). He sees both of those groups as putting forth an elitist program in opposition to education's "egalitarian motif" (75). Furthermore, White suggests that the effectiveness of basic writing can be proven, and presents yet-unpublished research to support his claim.

This is fairly traditional experimental research. He presents data from two sets of institutional experiments, one conducted by California State University's Institutional Research Office and the other by the New Jersey Basic Skills Council. The California State study tabulated retention among first-year students from Fall, 1978, and found that students who took the English Placement Test remained in college at markedly higher percentages than the freshman class as a whole. Further, those who tested into Basic Writing also were retained in greater numbers than the entire population of first-year students. White acknowledges that these data are difficult to interpret but suggest the success of the basic writing program at the numerous CSU campuses.

The New Jersey data, similar in design, had a larger scope. Researchers studied first-year students at all public institutions of higher 
education in New Jersey, from community college to large, researchoriented four-year universities. The New Jersey study also examined multiple areas of remediation: reading, writing, and math. The results of the study were much like the other to which White refers. In New Jersey, White explains, "students who do not complete the basic writing courses leave school at a much higher rate" (82). So although White cautions about generalizing too much from the studies, he suggests we can gather data to show that basic writing "can help most lowscoring students succeed" (83).

White's article has elements of philosophical research as well. Specifically, White enters into a dialectic with the new abolitionists. Stephen North suggests that philosophical research contains the "back and forth of argument and counter-argument," a dialectical conversation between multiple voices (106). The philosophical researcher examines previous scholarly work and questions either the premises or the argument's validity (North 106). White connects his argument to previous listserv conversations: "writing program administrators on the WPA e-mail computer network are widely sympathetic with abolitionism, despite its implications for their jobs" (77). Dialectic with Sharon Crowley is also established. White calls into question Crowley's problematization of the notion of student need, thus questioning one of her major premises. White partially agrees with the claim that little has been done to document the success of basic studies, but offers data to counter the trend. As we noted above, the dialectic continued. Crowley, in her response to the article, suggests that she had an antielitist agenda in mind when she advocated for abolition. She rejects the notion that her position can be construed as neoconservative and refers to a right-wing publication, Academic Questions, which also challenged her modest proposal. However, Crowley does not respond to the data. So in effect, Crowley responds to White as a philosopher but not as an experimentalist. To return to our thesis, there is essentially no ideological opposition here. White and Crowley agree that we ought to work to counter the elitism of higher education. The difference is methodological. Crowley seems to want to engage White philosophically, but scarcely acknowledges the empirical data.

Tracey Baker and Peggy Jolly, in a primarily-experimental, 1999 Journal of Basic Writing article, are less willing than White to shed their practitioner identity. In "The Hard Evidence: Documenting the Effectiveness of a Basic Writing Program," Baker and Jolly present the results of a thorough program evaluation of basic writing at their home institution. Baker and Jolly are primarily interested in retention and find "slightly higher" retention among basic writers compared to overall enrollment. So their work is primarily experimental. Unlike White, Baker and Jolly are not philosophical. Their article is not a "think piece," nor do they situate their work very heavily in ongoing dialectic, al- 
though they briefly allude to arguments put forth by Bruce Horner, Richard Miller, and Ira Shor. More than responding to other scholars, they are responding to a localized, institutional call to "assess retention rates for the student body" (28). So as experimentalists, their work has an immediate exigency: justify to administration the effectiveness of basic writing in order to maintain the program's very existence.

But elements of practitioner knowledge also lurk in their report. In fact, Baker and Jolly, to their credit, have a meta-awareness of their methodology and defend the use of "instincts, sixth sense, and anecdotal reports" (28). They suggest that experimental knowledge is most rhetorically effective, given their institutional context, but suggest that the practitioner way of knowing "helps us understand our students, their strengths and weaknesses, even as we also study the hard facts. One without the other tends to distort the picture - at least within individual institutions" (28). Here, Baker and Jolly suggest that practitioner knowledge is particularly useful at the micro, localized level. They don't suggest their practitioner knowledge applies to everybody, everywhere; rather, they assert such a viewpoint further contextualizes their local conditions.

But in this report, Baker and Jolly are primarily experimentalists. They lay out their methodology and process under such categories as "Variables" and "Data Collection." The article, in fact, reads much like a piece of scholarship from the social sciences. They pay particular, though not exclusive, attention to retention, important since one of the critiques from the new abolitionists has been that basic writing is in part a tool of forces that do not wish to see ethnic minorities and working-class students receive their degrees. They study the first-year basic writing populations from the Fall Terms, 1993 and 1994, and track their progress. Retention was especially striking, and Baker and Jolly present their findings in tables so readers can easily grasp their various findings. Fourth-year retention for the general enrollment was only 23 percent, but for the sample population - all students enrolled in basic writing - it was 50 percent (32).

Baker and Jolly are also interested in current classification of the retained students after four years. The majority (73 percent) are either sophomores or juniors. Nine percent are seniors and three are enrolled in graduate programs in ESL. It's difficult to do much with this data, especially since the authors don't indicate the status of the entire population of students who began school in 1993 or 1994 . Baker and Jolly looked at their sample population's grade point averages as a third variable, but found nothing conclusive. In some years, GPAs were higher among retained students and in other years GPAs were higher among students who left college: "apparently, grade point average is not a variable which predicts whether students will complete university studies" (35). But we should note that Baker and Jolly have begun 
to widen the conversation to include more than just retention and they base their generalizations on a research methodology that is designed to produce convincing generalizations.

In "Teaching in the Spaces Between: What Basic Writing Students Can Teach Us," Howard Tinberg makes two major claims. First, basic writing professionals need to spend more time listening to basic writers. Second, we should stop concentrating on the question of abolition and start concentrating on the question, "Whose responsibility is it to promote broad-based literacy in this nation?" Tinberg discusses the abolition debate briefly and then moves on to what he considers more important matters: students. His style is much like that of Mike Rose, as he tells stories about his students and quotes quite extensively from their writing. In his analysis, Tinberg sees in his basic writing students "edginess" as well as "agitation and uncertainty" (79). Underneath the problems with clarity and fluency, he argues, are insightful critiques of the system that placed them in remediation. Tinberg urges readers to do the kind of careful listening and analysis of the words of basic writing students, and consider the immense amount of knowledge that students bring with them to college. He ultimately advocates fighting for the preservation of basic writing, since the course is a space where educational institutions can listen and respond to an important group of students.

Of course, Tinberg's article is primarily a practitioner piece of scholarship. Readers learn about Tinberg's teaching style, that he thematizes his basic writing course around literacy acquisition, that he incorporates readings by Richard Rodriguez and Tim O'Brien and Frederick Douglass, and that he assigns a literacy narrative. Not only does he discuss classroom techniques, he incorporates many quotations from his students. Here Tinberg distinguishes himself. This multivocal text allows students to weigh in on professional conversations about education's role in society. We learn about Denise, a nontraditional student juggling more responsibilities and commitments than most students we encounter. Denise critiques the school systems she has encountered:

Well when I was in school. I was always in a special needs class all through middle school and high school. I was always in a one classroom type of thing.I watched all the other kids go to room to room and I was upset about it at the time. I felt like I wasn't like the other kids in school. And when I was all done with school I was going to have this training skill after I graduated. But I didn't get to do it. They said I was to old to do it. They said I was to old for it or unable to do it. So I was mad for a long time about it. That. But I got over it though. I don't know if I was read to. (84) 
Tinberg uses Denise's words to illustrate the insights that basic writers have about education and society.

Tinberg is also a philosopher of sorts. He frames his article with current debates between scholars and politicians. He draws on the anti-open-admissions rhetoric of Mayor Giuliani, as well as the debates among major scholars such as David Bartholomae, Ira Shor and Min Zhan Lu. So his work is in dialectic with these individuals. But he takes it a step further and allows his students to be in dialectic with the politicians and scholars. Tinberg's dialectic has a unique agenda: allow a new set of voices to enter the ongoing conversation. Toward the end of his report, he even "cites" students in the way scholars traditionally cite other scholars, referring to their claims and premises with an air of respect for their writing.

Ira Shor, in "Our Apartheid: Writing Instruction \& Inequality," presents the piece of research that is methodologically most complicated and most interesting. Shor, a leading figure in critical pedagogy and collaborator and friend to Freire, argues that basic writing does more harm than good. Remediation, an enemy to both egalitarianism and progressive education, only serves to separate students into worthy and unworthy groups, Shor asserts. Further, basic writing younger sibling to composition - helps maintain a system of corrupt labor practices among institutions of higher education by creating an underclass of students taught by an underclass of instructors:

$\mathrm{BW} /$ comp is a cash cow - full-tuition paid by students while part-time wages are paid to teachers. No costly equipment needed as in engineering labs or nursing departments. BW/ comp is like the former colony on India, the jewel in the crown, a territory generating lots of wealth for the imperial metropoles of lit, grad school, and administration. (99)

Most damning to remediation, Shor charges that basic writing is a form of containment, "a gate below the gate" to hinder underprepared largely minority and working-class - students (94). Shor carefully traces the role tracking has played in the history of American education and asserts basic writing's primary achievement has been to "slow down the students' progress toward the college degree which could enable them to expect higher wages in the job market" (95).

Shor is primarily an historian in this piece. He carefully lays out a narrative of education as an historically-dubious agent. Specifically, he relates composition's early history at Harvard as an extension of the admissions office, a means to weed out those not worthy to be Harvard Men. The narrative continues into the turbulent 1960s and 1970 s when student movements began to demand "democratic change" 
and egalitarianism in the classroom and beyond. Open-admissions, of course, became one of the prizes won by these democratizers of higher education, and Shor suggests "an extra layer of control was apparently needed to discipline students in an undisciplined age" (92). The punishment was basic writing, according to Shor's narrative, and it was a successful punishment, too. Shor points to the widening wealth and income gap, racial and gender inequality, and concludes that higher education has successfully squelched education as democratizer (93).

North considers the identification of patterns and the creation of narrative to be the primary roles of historians, the means to disseminating research and data. Ira Shor does just this; he locates relevant historical occurrences and finds a common bond: education as a means to tracking and sorting. He creates a narrative that tells the story of composition and basic writing, situates that story's relevance to professionals in basic writing, and explains that story's implications for our work. Yet his narrative is immersed in an explicit agenda and Shor makes no attempt to hide his ideology. Perhaps this is true of all historians, who likely can never fully separate their work from their positionalities and politics. Shor, however, goes a step further and makes radical proposals at the end of his piece. He not only proposes that we ought to mainstream basic writing students into the general population, he also suggests that the Conference on College Composition and Communication draft 1) a labor policy against the use of parttime instructors, and 2) a "curricular policy against tracking, testing, and skills-based instruction" (100).

Shor's methodology takes a sharp turn at the end, and it is here where Shor transcends North's historian category. Readers expect Shor to conclude his narrative with the argument for mainstreaming. Throughout his historical account, he deplores the negative aspects of basic writing and builds up audience expectation of an argumentative conclusion. But then he abruptly lobbies for his professional organization to take practical action. His "solution" is consistent with the radical, civic action for which critical pedagogy aims. Shor refuses to make a generic call-to-action and merely advocate for mainstreaming. Instead, he indicates the specific institutional manner that he thinks will bring about change. Ultimately, then, in terms of methodology Shor is not merely an historian, but also a progressive reformer. But this leaves those who would engage in dialectic with him in an awkward methodological posture. To dispute his practical proposal at the end allows him to respond that the historical issues are central, while a different reading of the history would necessarily scant the call for action. This situation is typical of a research community that, to recall the metaphor of our title, keeps going around in circles. 


\section{Coming to Conclusions}

To mainstream or not to mainstream. That is the question. Whether the group we label "basic writers" ought to be placed in standard first-year composition or a developmental-level course "below" composition is a debate fraught with political and ideological implications. Who has access to higher education? Is college for everybody? How do educational institutions sort and place students? Do we enculturate students in such a way that their futures, and by extension their material conditions, become set in stone? What kind of language belongs in the academy? As rhetoricians and public intellectuals, how can we shape institutions that are more ethical and diverse? We maintain that although the mainstreaming debate raises complicated and provocative questions such as these, the primary reason basic writing scholars differ so emphatically is because they differ methodologically - not politically. It is doubtful that we will unite under a single research methodology, and equally doubtful that this would be desirable. Yet those of us committed to Basic Writing and the democratic potential of education also need to work toward our field's intellectual maturity. We contend this maturity can advance if we carefully and ethically take account of methodologies other than our own in our scholarship. For example, we should take particular note of a massive research study issued by The Institute for Higher Education Policy - a report most of those in our field will never read-which concludes, "The social and economic consequences of not providing remedial education [at the college level] are high" (College Remediation viii). In short, we need to do a better job of listening to each other in order to stop moving in circles.

\section{Works Cited}

Baker, Tracey and Peggy Jolly. "The Hard Evidence: Documenting the Effectiveness of a Basic Writing Program." Journal of Basic Writing 18 (1999): 27-39.

Bloom, Lynn Z., Donald A. Daiker, and Edward M. White, eds. Composition in the Twenty-First Century: Crisis and Change. Carbondale: Southern Illinois UP, 1996.

Braddock, Richard, Richard Lloyd-Jones and Lowell Schoer. Research in Written Composition. Urbana: NCTE, 1963.

College Remediation: What It Is, What It Costs, What's At Stake. The Institute for Higher Education Policy. December, 1998.

Connors, Robert J. "The Abolition Debate in Composition: A Short History." Bloom et al 47-63. 
Crowley, Sharon. Composition in the University: Historical and Polemical Essays. Pittsburgh: U of Pittsburgh P, 1998.

-. "Response to Edward M. White." Journal of Basic Writing 15 (1996): 88-91.

Elbow, Peter. "Writing Assessment in the 21st Century: A Utopian View." Bloom et al. 83-100.

Hartwell, Patrick. "Grammar, Grammars, and the Teaching of Grammar." College English 47 (1985): 105-27.

Hillocks, George. Research on Written Composition: New Directions for Teaching. Urbana, IL: ERIC Clearinghouse on Reading and Communication Skills and the National Conference on Research in English, 1986.

North, Stephen. The Making of Knowledge in Composition: Portrait of an Emerging Field. Portsmouth, NH: Boynton/Cook Heinemann, 1987.

Ramage, John. "The Universal Requirement in First-Year Composition." BasicWriting e-Journal1 (1999). <http://www.asu.edu/clas/ english/composition/cbw/journal_1.htm> Accessed 8 February, 2000.

Rose, Mike. Lives on the Boundary. New York: Free Press, 1989.

Shor, Ira. "Our Apartheid: Writing Instruction \& Inequality." Journal of Basic Writing 16.1 (1997): 91-104.

Tinberg, Howard. "Teaching in the Spaces Between: What Basic Writing Students Can Teach Us." Journal of Basic Writing 17.2 (1998): 76-90.

White, Edward M. "The Importance of Placement and Basic Studies: Helping Students Succeed Under the New Elitism." Journal of Basic Writing 14 (1995): 75-84. 
Keith Gilyard

\section{BASIC WRITING, COST EFFECTIVENESS, AND IDEOLOGY}

ABSTRACT: The debate about required composition courses like Basic Writing, some of which played out in JBW in the 1990s, has taken on new urgency given recent decisions and inclinations to eliminate such courses at four-year colleges in CUNY and elsewhere. This essay revisits that debate, particularly a strand of it that took place in the pages of this journal, and argues for movement beyond a perceived either/or dilemma.

As I recall images of fifteen years of teaching Basic Writing at the City University of New York, the accompanying sound track includes a persistent refrain: "Keith, it's not cost effective." Some administrators uttered the phrase sternly, some sympathetically. But all spoke those words invariably when, mostly as a WPA, I offered suggestions about reducing class sizes, making full-time hires in composition, or reconfiguring course credits. I always stressed the notion of effective relative to matters of student learning and discoursal positioning, but almost always cost ruled. Such expense-oriented educational pronouncements by college administrators are not solely responsible for the full attack on Basic Writing in the CUNY system now underway, as summarized in Barbara Gleason's "Remediation Phase-Out at CUNY," but such rhetoric serves the assault, one that has been developing for years, well. When conservative officials expel Basic Writing and its generative possibilities from four-year colleges, partly to serve the purposes of corporate elites, as radical critics remind us, they sell the restrictive move to the larger public with rap about standards, quality, and fiscal responsibility. The real deal, however, is that investing sufficiently in a university population that consists of a solid majority of people of color, who suffer disproportionately at the hands of the corporate elite, does not rank highly on conservative agendas.

Diminished possibilities, both in terms of funding, curriculum, and my own teaching creativity factored into my decision to leave

Keith Gilyard is Professor of English at Penn State and Chair of CCCC. He is author and editor of several books, most recently Race, Rhetoric, and Composition (Boynton/Cook, 1999). He spent almost twenty years at CUNY, four as an undergraduate at the dawn of the open admissions era and fifteen as a teacher and WPA, mainly at Medgar Evers College. He is also a former director of the Writing Program at Syracuse University. 
CUNY in 1994. I left, though, fairly wise about writing practices and forever curious about what was going on back "home." I am, therefore, grateful for the chance to contribute to $J B W$, one of the most important intellectual components of CUNY. In fact, I have chosen to chime in on a conversation about "new abolitionism" that has evolved in the journal over the past four or five years, one that is vital because it speaks to the very rationale for Basic Writing and for required composition courses overall; therefore, it is a conversation relevant to the up-to-the-minute situation at CUNY and elsewhere. Ironically, I am stuck once again on the question of cost effectiveness. I guess administrators taught me well, though of course I am focusing (always have really) on the long-term social costs of policy positions we assume, not on the immediate bottom lines with which too many administrators are obsessed.

The strand of thinking I am referencing began with a 1995 article by Ed White titled "The Importance of Placement and Basic Studies: Helping Students Succeed under the New Elitism." White expresses wariness over neoconservative moves to undermine initiatives such as Basic Writing, programs that in his view signal the egalitarian ideal in education. He presents the results of large-scale studies conducted in California and New Jersey that indicate the worth of appropriate placement programs coupled with well conceived instructional designs. Fully cognizant of the exclusionary, gate-keeping function that writing courses under any name may serve, White nonetheless maintains that certain kinds of required courses help to further an ameliorating mission. I am generally sympathetic to White's position, even as I recognize several legitimate debates that could ensue from the position he takes. However, the spiciest part of his critique is his charge that academics like Sharon Crowley who call for an end to required writing courses are in league, albeit unwittingly, with forces that aim to limit access and success for traditionally underrepresented students. Crowley objects of course in her 1996 response. And rightfully so. She couldn't be farther removed from being the Right's house theorist. But her new abolitionist position is fraught with problems, the main one being the relinquishing in academe of hard won, potentially radical, spaces. If "critical literacy is both a narrative for agency as well as a referent for critique," as Henry Giroux argues(10), and if the purpose of a general education is to help position students to question systematically and perhaps even contest the forces that dominate their lives rather than to train them to become simply the victims or even "innocent" beneficiaries of those forces, then any space one gets to promote agency and critical faculty is valuable territory not to be conceded. Whether we call it Basic Writing, Freshman Composition, or whatever, sites that privilege the development of authentic student voices and enable more sophisticated analyses of discursive practices and the re- 
lations of those practices to power are as worthy of being required as any courses in the academy. Naturally, my position presupposes that such sites should simultaneously be progressive with respect to labor practices and the distribution of credits to students. What I am arguing as well is that the stress on empirical evidence to justify such courses, a matter White and Crowley seem to agree upon, is mostly beside the point. If we do not ask if there is need for required composition but, rather, if there is need to teach critical language awareness, of which producing text is a central part, whenever we can command sites to do so, I cannot fathom how the radically inclined can answer in the negative. Empirical studies are necessary to document good work, but they are not needed to make the initial case.

Crowley correctly points to Harvard University as the origin of the universal composition requirement, a practice that was exclusionary from the outset given its use to stamp the "Harvard man." Crowley writes, "I doubt whether the exclusionary institutional function of the universal requirement can be radically altered at this late date in its history" (89) and "I doubt whether we serve 'new students' well by using mass examinations to segregate them into classrooms that can be readily identified as remedial or special" (90). Doubt seems a rather weak expression of mindset when attached to such radical new abolitionist proposals. But such intellectual caution is appropriate. It's not the strongest argument to make a case against a practice merely because of its origins. That rules out the revolutionary possibilities of appropriation. English itself, much less its written, academically sanctioned versions, has served slavery, colonialism, class oppression, and gender exploitation. And although there is talk from time to time of limiting its reach around the world, the practical situation is that it's a major linguistic tool we have had to and will have to employ. The civil rights, women's liberation, and students' movements that Crowley and I both take pride in were all floated on various forms English. Some of those forms, like Black English Vernacular, were forged in the crucible of resistance and struggle. African Americans as a whole did not, like Morrison's Sixo, give up on English because there was no future in it. They cast a future largely in Africanized English. This is an instructive example.

I am certainly no fan of old-style Harvard elitism. All that snobbishness is a heavy tab to pay to get a Du Bois or Cornel West every eighty years. Talk about cost ineffective. I've always placed great credence in the joke that Harvard has ruined more Black men than bad whiskey (a joke I've heard with Yale, Princeton, and other schools substituted). Nonetheless, the point is that structures, from wherever they derive, can and do serve as vehicles for change. Such structures have to be corrupted - when they can be.

Around the same time White was writing for $J B W$, and a year 
after I left CUNY, I attended a Basic Writing symposium at the University of Pittsburgh coordinated by Jim Seitz. At the gathering, at which Deborah Mutnick of Long Island University, a former graduate student of mine who was still teaching Basic Writing, also spoke, I articulated an abolitionist position. Indeed it was impossible to defend, as Ira Shor often points out insightfully, Basic Writing as practiced by many institutions, especially several of the colleges of CUNY. I had seen firsthand, indeed participated in, some of the inane recycling of students through non-credit courses, the skill-and-drill silliness, misdirected - but hey, cost effective - testing crazes, and exploitative personnel practices. I argued then that without being able to better demonstrate the efficacy of Basic Writing, we perhaps ought to do away with it altogether. However, at that symposium I heard from and met a group of Deborah's students who reaffirmed for me the possibilities of Basic Writing. Not simply did they write, present, and perform in noteworthy fashion, they argued cogently for the worth of their experiences in Basic Writing. That was a fine demonstration of narrative agency, not up to certain empirical standards, but still sound evidence to me, which was backed up by Deborah's subsequent book Writing in an Alien World: Basic Writing and the Struggle for Equality in Higher Education. Of course testimonials will never answer the question of how we know whether students would have fared as well or better if they had not taken Basic Writing, a question often posed by Shor. Responding, in his $1997 J B W$ article, "Our Apartheid: Writing Instruction and Inequality," to statistics supplied by Karen Greenberg about the percentage of Hunter College graduates who were basic writing graduates, Shor argued that "These figures mean very little. What must be proved is that these students could not have graduated without BW" (96). That can never be proved, and Shor and every methodologist knows that. You cannot prove a negative. So the must Shor speaks of cannot possibly be the variable upon which debate hinges. Moreover, we do not construct useful educational theories based on the absence of phenomena; the point is to study the phenomena that do occur and make the most intelligent and informed judgment we can about what the phenomena signify. Deborah's students were positive signifiers, as were my own students in my Basic Writing classes on the best of days.

To be clear, I make no blanket endorsement of Basic Writing programs. I am just as likely to favor certain "mainstreaming" efforts like the program run by Barbara Gleason and Mary Soliday at City College. Shor mentioned the project, one I evaluated, as did Sharon Crowley. The high points of my work were my interviews with students, some of whom hailed from Haiti, Nigeria, India, Poland, South Korea, Grenada, Guyana, The Dominican Republic, and the USA. Almost all of them testified to the intensity and rigor of the courses they 
had taken; some wanted more writing courses. Nearly all had entertained initial doubts about their academic abilities but subsequently expressed confidence in their prospects for continuing in college. The point to make here is simple; if you have a good show, go with it, whatever the institutional structure that has to be worked.

Ira Shor got a lot of things right, as he usually does, in that 1997 $J B W$ piece. He is virtually nonpareil in his macro-level analysis of the connections between required composition and U.S. political economy, and he makes a powerful statement of the new abolitionist idea. But I also think the responses to his article by Greenberg and Terry Collins have considerable merit. They are aware that Shor's bleak Basic Writing landscape doesn't adequately account for sites like Mutnick's classes or properly reckon with the fact that there is no uniform set of practices, or even definition, of Basic Writing. They allow for more possibilities in Basic Writing courses and express some legitimate concerns. As Greenberg asks with respect to the abolition of Basic Writing:

Does anyone really believe that students will be able to get this help in freshman composition courses, where the class size is larger, where dialect variation is often perceived as "error," and where the demands are for college-level conceptualization, organization, fluency, and mastery of English conventions? (92)

This question is also relevant to the notion of abolishing required Freshman English, which brings me to another question I ponder when I consider new abolitionism. If we, with all of our critical perspectives on literacy, relinquish our required claim on students inside the institutions in which we work, where will they attain the valuable knowledge we could help them create in required courses? In writing and rhetoric electives, which relatively few would take? In literature courses where they still have a better chance of getting shot down by the Western European canon than being lifted by progressive pedagogy? Which disciplines are less oppressive? Philosophy, the racist Enlightenment version? History, "his story?" Rather than that kind of abandonment, I prefer policies that will give students the greatest chance possible to learn from people like Crowley and Greenberg.

Terry Collins acknowledges that

Shor is surely right that there is a history of exclusionist practice in higher education, grounded in race, class, and gender assumptions, and some practices in writing instruction and tracking are undoubtedly tied to this history. It is an unfair corollary that there is a Basic Writing industry acting out a cynical apartheid agenda. Rather, there are any number of 
situated, institutionally constrained iterations of things like "Basic Writing," some more fortunately located than others, some more successful in resisting pariah status than others, some formed with more authentic educational purposes than others. (99)

I take this to be a fair assessment and is a view compatible with some of the best thinking in the field, Bruce Horner and Min-Zhan Lu's Representing the "Other": Basic Writers and the Teaching of Basic Writing, for example. And having visited Terry at the University of Minnesota, I can say that he is another scholar you want students to be around. But there exist too few productive sites, and many blatantly unproductive ones, the reason Shor's critique is yet necessary even if it is not to be embraced absolutely. Shor thinks composition's future lies in discipline-based, field-based, critical social work. Critical? Field? Fine. But I'm not all the way on board with that vision for I'm not ready to give up an important interdisciplinary site, which I think courses in critical language awareness can be. Sure, required writing courses reproduce dominant ideologies, serve regulatory ends, and stifle creativity, but that is not all they do. The possibility for challenge and change, which could mean sustained access and opportunity for many students, is undeniably present. Some of us know this through personal experience both as students and teachers. We challenged and lost, then won, then lost, persevered to win some more. . .and so it goes.

Valued colleagues are doing tremendous work in various locations. Most of these locations are unstable and we ought not to aid in their further destabilization by theorizing their category out of existence from afar. We should support and enhance critical practice where we find it. We cannot afford otherwise.

\section{Works Cited}

Collins, Terence G. "A Response to Ira Shor's 'Our Apartheid: Writing Instruction and Inequality.' " Journal of Basic Writing 16.2 (Fall 1997): 95-100.

Crowley, Sharon. "A Response to Ed White's 'The Importance of Placement and Basic Studies.'" JBW15.1 (Summer 1996): 88-91.

Giroux, Henry A. "Literacy and the Pedagogy of Political Empowerment." In Literacy: Reading the Word and the World. Paulo Freire and Donaldo Macedo. New York: Bergin \& Garvey, 1987, 1-27.

Gleason, Barbara. "Remediation Phase-Out at CUNY: The 'Equity versus Excellence' Controversy." CCC51.3 (February 2000): 488-491. 
Greenberg, Karen. "A Response to Ira Shor's 'Our Apartheid: Writing Instruction and Inequality."' JBW16.2 (Fall 1997): 90-94.

Horner, Bruce, and Min Zhan-Lu. Representing the "Other": Basic Writers and the Teaching of Basic Writing. Urbana, IL: NCTE, 1999.

Mutnick, Deborah. Writing in an Alien World: Basic Writing and the Struggle for Equality in Higher Education. Portsmouth, NH: Boynton/ Cook, 1996.

Shor, Ira. "Our Apartheid: Writing Instruction and Inequality." JBW 16.1 (Spring 1997): 91-104.

- - . "Inequality (Still) Rules: Reply to Collins and Greenberg." JBW 17.1 (Spring 1998): 104-108.

White, Edward M. "The Importance of Placement and Basic Studies: Helping Students Succeed Under the New Elitism." JBW14.2 (Fall 1995): 75-84. 


\title{
Min-Zhan Lu and Bruce Horner
}

\section{EXPECTATIONS, INTERPRETATIONS AND CONTRIBUTIONS OF BASIC WRITING}

\begin{abstract}
This essay argues that Basic Writing students, teachers, and scholarship are crucial to enabling colleges and universities to live up to their ideals of diversity, interdisciplinarity, and student-centered learning. BW scholars and teachers have developed ways to work with students to better understand the different perspectives they bring to their writing and learning, and to use those perspectives to break down barriers between academic and non-academic worlds and develop "borderland" knowledge and perspectives. The authors call for more research exploring the potential of basic writing students to develop such perspectives, and for research exploring the implications of BW scholarship for assisting in the retention of students and the revitalization of faculty committed to interdisciplinary learning. Finally, they call on working with BW students to assist teachers in researching and developing ways of fighting the material social barriers to the education of students and teachers.
\end{abstract}

To go by the mission statements in current college catalogues, "diversity," "interdisciplinarity," and "student-centered learning" are among the most publicized goals of higher education. According to these catalogues, institutions across the nation expect to serve a new student body diverse in not only race and ethnicity but also economic class, gender, sex, age, and educational or work experiences. The academy expects students to take part in programs designed to develop new styles of thinking and writing and new voices which break down the boundaries separating academic fields and isolating the academy from society at large. Furthermore, the academy expects faculty to

Min-Zhan Lu is Associate Professor of English and Endowment Professor of the Humanities at Drake University, where she teaches courses in writing, autobiography, fiction, critical theory, and adolescent literature. She has written essays on the use of cultural dissonance in teaching and the politics of representing difference. Her books include Comp Tales (Longman, 1999), coedited with Richard Haswell, and Crossings (Duquesne UP, forthcoming), a work of creative nonfiction.

Bruce Homer is Associate Professor and Associate Chair of English at Drake University, where he teaches courses in writing, song criticism, and literacy studies. His books include Terms of Work for Composition: A Materialist Critique (SUNY Press, forthcoming), and Representing the "Other": Basic Writers and the Teaching of Basic Writing, co-authored with MinZhan Lu (NCTE, 1999). His essays on composition have appeared in College Composition and Communication, College English, English Education, and elsewhere. 
treat students as the center of learning rather than the passive receivers of established knowledge.

Given these grand expectations, how might the field of Basic Writing challenge the academy to turn its paper ideals into lived realities? One direction would be to articulate the place of Basic Writing in an academy which pays more than lip service to its vow to inculcate diversity, interdisciplinarity, and student-centered learning. This would involve reviewing Basic Writing's historical contributions, through faculty and student efforts, to challenge traditional institutional complacency towards uniformity in the student body, disciplinary purity, and top-down transmission of established knowledge. In many ways, Basic Writing came into being by fighting for the educational rights of students traditionally kept outside the gates of the academy as a result of their less privileged class, gender, race, ethnicity, age, or previous educational background. And it had to do so by confronting the deficit model underlying traditional academic interpretations of why students produce "errors."

The academy had traditionally approached error from "top down," and thus had understood error as an indication of the students' lack of cognitive skill, linguistic knowledge, or motivation to learn the rules of academic discourse. By contrast, Basic Writing researchers set out to learn about the viewpoints and efforts of students. Basic Writing has gathered information on what individual students were actually thinking, trying to do, and aiming to achieve when producing textual deviations from the established norms promoted in various college classrooms. It has compiled a rich pool of data demonstrating the cognitive agency of basic writers and a whole range of logics behind seemingly random departures from conventional syntax, tone of voice, organization, and forms of argument. Such student-centered research has led to a wealth of pedagogical strategies to help students improve their writing, strategies centered on what the students actually need rather than what the faculty assume the students need (Bartholomae, "Study of Error"; Hull; Lees; Shaughnessy; Tricomi; Wall). In short, Basic Writing has always been at the forefront of efforts to increase diversity and inculcate student-centered learning.

However, given the political climate of the late sixties and the seventies, Basic Writing teachers and program directors often had to argue for its legitimacy through invoking problematic images, such as depicting basic writing students as "foreigners" and "beginners" (see Horner, "Mapping"). The imagery of the "foreigner" was often used to depict basic writers as different from the students previously attending college, not in intelligence or motivation but in educational and family background. The imagery of the "beginner" was often used to depict basic writers as inexperienced, new at writing as a result of the inequities in our nation's distribution of educational resources and 
opportunities, rather than as lacking in capacity and ambition as learners. Both moves are indicative of the political climate of the time, when a significant number of those in positions of power within and outside the academy had openly portrayed basic writers as "barbarians" and a threat to the academy's integrity and traditions. The images of the beginner and foreigner worked effectively to appease the opponents of Basic Writing by reassuring them that although Basic Writers were newcomers to academic culture, they were also model immigrants eager and able to learn the ways of the academy. Thus, their presence would not disrupt business as usual. At the same time, these images emphasize society's moral obligation to remedy its longstanding history of discrimination by extending to these native-born "foreigners" and adult "beginners" the educational opportunities denied them as a result of social injustice.

The recent public trend to put a "multi-" or "trans" before everything - "culture," "media," or "national" - has the potential to open some new routes for asserting the place of Basic Writing in the academy. To begin with, if one of the catalogued grand expectations of the academy is to advance interdisciplinarity and service learning, which allegedly means cultivating ways of thinking and speaking that break down the boundaries separating the academy and society at large and isolating academic disciplines, then we might use existing research in Basic Writing to foreground the capacity and aspirations of basic writers to meet this institutional expectation. For instance, if academic language represents the language of those who teach in the academy and the language of those whose writings we regularly assign our students to read, then the popularity of Gloria Anzaldúa's writing in college readers suggests that the new voice endorsed by the academy is increasingly more diverse and hybrid. It has become trendy not only to assign writings by authors interested in forging hybrid styles out of multiple languages in courses listed under "interdisciplinary programs" - women's studies, cultural studies, environmental studies but also to host symposia and workshops where faculty exchange experiences in developing such new voices in their own work and pedagogies which invite students to read and write from the borderlands (see Bridwell-Bowles; Lunsford and Ousgane).

Given these trends in the official academic climate, the same aspects which had made basic writers appear "alien" and "novice" to an academy interested in melting differences into the pot of disciplinary purity and academic uniformity - namely, these students' need to respond to the dissonance between the discourses of school, home, and work when reading or writing and their reluctance to take an either/ or approach to these competing ways of thinking and speaking - should now mark them as experienced practitioners of the borderlands and, therefore, ideal citizens of an academy aiming to inculcate diversity, 
interdisciplinarity, and service learning. In theory, these students are indeed not only the kinds of students the academy officially expects to serve, because of the diversity in their backgrounds, but also the kinds of students most interested in developing the hybrid voices the academy expects faculty and students to inculcate: hence, the kinds of students the academy needs. In fact, these students have a lot to teach the general faculty about the challenges facing writers who try to read and write from the borderlands of cultures and disciplines, and about the kinds of pedagogy which can best help students develop new voices on those borderlands.

To assert this potential place of Basic Writing in the general curriculum, we need more research on the contributions of basic writers to the academy not just in terms of body counts in statistics on racial, ethnic, gender, and age ratios, but more importantly, as writers and thinkers with experiences, ambitions, and perseverance for living in the kind of borderland the academy is vowing to become ( see, for example, Gilyard; Soliday, "Translating"; Sternglass; Villanueva; Wallace and Bell). That is, we need to create a discourse which presents Basic Writing as not only a moral imperative for an academy willing to pay more than lip service to its paper ideals but also a practical imperative-a means to improve student retention and faculty vitality, two aspects crucial to the well being of any institution.

One direction this research might take would be to further examine discrepancies between academic interpretations of deviations in the writings of published writers, on the one hand, and its interpretations of deviations in the writings of students, on the other. We have in mind here, for example, the tendency, on the one hand, to celebrate deviation in texts by writers such as Gloria Anzaldúa as an expression of her desire and efforts to live in the borderlands of cultures and disciplines while, on the other hand, continuing to treat deviation in student writings only as "errors" - evidence of the writer's lack of cognitive or linguistic sophistication (see Lu, "The Vitality" and "Professing Multiculturalism"). There is a continued refusal to acknowledge the desire and efforts of students to think and write in the borderlands even as they learn to become more experienced users of the established discourses of individual sites. We also need more research which challenges discrepancies between the kinds of voice the academy demands of students labeled Basic Writers and the kind of voice it expects of other members of the academy. On many campuses, the effort to write from the borderlands is still preserved as the privilege of those who have earned the right to do "real" work within the academy. Curriculum structures often indicate that students are not ready to venture into the borderlands and experiment with alternative voices - earn credits in interdisciplinary programs - until after they have proven they have been naturalized into the supposedly univocal context of aca- 
demic culture or individual disciplines - i.e., after they have been placed out of Basic Writing courses. The borderlands has thus become an elite institutional space reserved for writers already fluent in the socalled academic discourse, while basic writers continue to be exiled from the real, social borderlands they occupy in real life by being forced to simplify the context of their writing into a univocal "academic community." They have continually been told that they are simply not yet cognitively, emotionally, and psychologically "ready" - just as elementary school children traditionally have been perceived as being too immature - to handle the challenge of reading and writing in multivocal contexts.

To combat this elitist double standard, we need more research which treats basic writers as real historical agents and acknowledges the extent to which many basic writers are already living (out of social necessity and/or personal choice) in the borderlands of dissonant cultural sites when learning to read and write. ${ }^{1}$ We need research which acknowledges the interests of a significant number of basic writers in composing thoughts and texts which examine the power relations among diverse discursive sites rather than separating and hierarchizing the competing ways of thinking and speaking immediate to their school, work, and family lives. In short, we need more representations of basic writers as experienced and active-creative-practitioners of the kind of borderlands the academy officially expects the general faculty and students to inhabit.

We should also encourage research which focuses not only on what faculty and peer tutors have learned about basic writers but also on what, in the process of helping basic writers revise their writings, faculty and peer tutors have learned about themselves as thinkers and writers. For instance, Basic Writing teaching is marked by the challenge of figuring out the "logic" behind deviations basic writers produce in their writing. To what extent have faculty and peer tutors' efforts to learn to read and write about a text or context from the points of view of basic writers inspired them to consider perspectives other than the ones in which they have become fluent and have thus been locked into as a result of their own professional training? (See, for example, Hull and Rose.) To what extent have their efforts to help basic writers articulate the challenges they face when negotiating the dissonance of home, work, and school and to come up with strategies for tackling such challenges conceptually and syntactically enhanced faculty and peer tutor efforts to develop multivocal voices in their own writing? These are cogent questions for researchers. We need more research which presents basic writing students as making significant contributions to the efforts of faculty and peer tutors to think and write from the borderlands (see Soliday, "Translating").

We should encourage research which explores the implications 
of existing Basic Writing research and pedagogy for the general curriculum. Basic Writing teachers and scholars have long been involved in researching ways to treat basic writers as the center of learning, interpreting deviations in student writing in the context of the writer's aims and aspirations as a thinker and writer. It has developed research and pedagogies aimed at understanding the logic behind students' production of "errors" and at honoring the students' sophistication and ambition as thinkers and writers when helping them to revise their writing. For instance, when basic writers try to examine the strengths and limitations of the established norms of one discipline from the perspectives of a variety of disciplines and cultures, and when they try to forge more complex and hybrid viewpoints out of dissonant cultures, their existing command over standard written English often appears to "fall apart" (see Bartholomae, "Inventing"; Schwalm). Researchers have come up with a range of pedagogies for helping students to sustain these efforts when revising. Researchers in Basic Writing have argued that although basic writers can benefit from instruction which expands their exposure to the established norms of thinking and writing within individual disciplines, this kind of teaching by itself is not enough not only for those desiring to forge a hybrid voice out of competing discourse but also for students who wish to "master" such norms. Students lose motivation and trust in our ability to teach when faculty fail to grasp what each student has to tell us about what exactly he or she is trying to do on the conceptual and syntactic levels during a particular instance of writing.

Given the academy's catalogue expectations towards diversity in our new students' backgrounds and aspirations, towards more student-centered learning and teaching, and towards multivocal voices, the general faculty and students have a lot to learn from Basic Writing concerning the new and diverse problems surfacing in their learning and our teaching as they join us in meeting the academy's grand expectations. This is especially the case for those faculty directly involved in interdisciplinary programs and eager to encourage students to explore multivocal texts. Faculty failure to grasp the different challenges facing students when writing in univocal and multivocal contexts could lead students to distrust the faculty's explicit commitment to cultivate interdisciplinary perspectives and prevent faculty from helping students develop the voice they claim to expect. Thus, Basic Writing research and pedagogy can provide insights on how to improve student retention, especially the retention of those students who have taken seriously our catalogued expectations of diversity and interdisciplinarity but who end up in classrooms which continue to use "top down" and univocal approaches to knowledge.

Examining the contributions of Basic Writing research and pedagogy to the general curriculum could improve not only student reten- 
tion but also faculty revitalization. For instance, faculty in interdisciplinary programs often get depressed by the seemingly poor quality of student writing, when they take that to mean that some of their students have not been properly prepared, nor are sufficiently motivated, to learn the real subject the faculty are eager to teach. If deviations often mark moments in student writing where complex attempts are being made at both the conceptual and syntactic levels and when students take seriously the faculty's endorsement of multivocal voices, learning to work with these students on these deviations can offer real incentives to faculty in interdisciplinary programs. ${ }^{2}$ Engaging in student-centered writing instruction can help these faculty recognize the energy and sophistication students often bring to their learning in spite of the seemingly poor quality of the texts they produce. This may help these faculty reach the most motivated and ambitious of our students. Such contact can in turn boost the vitality of faculty members, inspiring them to become more interdisciplinary in their research and teaching. We need to encourage more research which explores the applicability to the general curriculum but especially interdisciplinary programs of existing Basic Writing research and pedagogies.

Finally, at a time when many Basic Writing programs are struggling simply to maintain what marginal institutional space they occupy, we need to call on our basic writers, well-versed as they are in the challenges of competing for institutional resources of time, space, and material support, to assist us in researching, documenting, and developing ways of fighting the material barriers to learning and contributing to society which academic and other institutions, despite their paper ideals, regularly place in the way of those who would aspire to join in achieving those ideals (on this strategy, see Horner, "Traditions" 393-94; Soliday, "Class" 739; and Thompson A23). Just as Basic Writing scholarship has benefited from recognizing students' cognitive and social agency, Basic Writing programs may benefit from recognizing, and drawing on, students' political agency. Such collaborative research with students can benefit not only the students themselves and those who work most closely with them, but also 1 ) interdisciplinary programs many of which trace their beginnings to the same movements to give a space and voice to the disenfranchised, and more generally 2) academic institutions as a whole. ${ }^{3}$ Many interdisciplinary programs in ethnic, cultural, women's, multicultural, and working-class studies were initiated during the same period as programs in Basic Writing, and were developed to meet not only the needs but demands of students previously not admitted or not recognized as having anything to contribute to the academy. In the current climate of academic downsizing, these programs, like Basic Writing programs, face the prospect of competing with more established, traditional academic programs for institutional space, as add-ons threatening academic integ- 
rity. Such programs might be called upon to live up to their own rhetoric of inclusion and to join Basic Writing programs and basic writing students in documenting both the material needs of students and their contributions to achieving the catalogued academic ideals. And similarly, academic institutions themselves can benefit from mobilizing such students as their true constituents, whose voices the academy not only should but needs to listen to if it is to maintain its integrity.

There is a long, if neglected, history of academic institutions changing not from the top down but from the ground up, transformed by each wave of "new" students pushing at their gates. Such studentsJews, blacks, returning GIs, women, immigrants, the working classhave almost always been viewed by the academy, and society at large, as a threat to the academic mission, people to be either ignored, assimilated, or rerouted away from the gates. Yet they have always improved any institution they entered, not only by contributing to the quality of learning and knowledge-making but also by holding the academy more firmly to the ideals it espouses - by putting "academic" truths to the test. Basic Writers, the latest of these institutional classes of students, have already forced the revision of many an academic "truth" through the new questions they ask, and force us to ask, and the new answers they present to our questions. We can expect, and demand, that our colleagues and institutions learn to expect and depend on basic writing to continue to do so, to the benefit of all.

\section{Notes}

1. See Gloria Anzaldúa's account of her own history with writing instruction in Lunsford.

2. See David Bartholomae's observations on the irony of attempts to "import 'multiple cultures" into classrooms which already represent various cultures in their students' writing practices, and of scholars going to archives to "'discover' working-class writing by women" on campuses "where young working-class women [students] write" ("Tidy House" 14-15, 17).

3. For a discussion of the difficulties of enlisting interdisciplinary programs and the academy generally in supporting composition programs, see Horner, Terms of Work Chapter Four. 


\section{Works Cited}

Bartholomae, David. "Inventing the University." When a Writer Can't Write: Studies in Writer's Block and Other Composing Problems. Ed. Mike Rose. NY: Guildford, 1985. 134-65.

- - . "The Study of Error." College Composition and Communication 31 (1980): 253-69.

- -. "The Tidy House: Basic Writing in the American Curriculum." Journal of Basic Writing 12.1 (Spring 1993): 4-21.

Bartholomae, David, and Anthony Petrosky. Facts, Artifacts and Counterfacts: Theory and Method for a Reading and Writing Course. Upper Montclair, NJ: Boynton/Cook, 1986.

Bridwell-Bowles, Lillian. "Discourse and Diversity: Experimental Writing within the Academy." College Composition and Communication 43 (1992): 349-68.

Gilyard, Keith. Voices of the Self: A Study of Language Competence. Detroit: Wayne State UP, 1991.

Horner, Bruce. "Mapping Errors and Expectations for Basic Writing: From the 'Frontier Field' to 'Border Country.'" Horner and Lu 117-36.

- -. Terms of Work for Composition: A Materialist Critique. Albany: State $\mathrm{U}$ of New York $\mathrm{P}$, forthcoming.

- -. "Traditions and Professionalization: Reconceiving Work in Composition." College Composition and Communication 51 (2000): 36698.

Horner, Bruce, and Min-Zhan Lu. Representing the "Other": Basic Writers and the Teaching of Basic Writing. Urbana, IL: National Council of Teachers of English, 1999.

Hull, Glynda. "Acts of Wonderment: Fixing Mistakes and Correcting Errors." Bartholomae and Petrosky 199-226.

Hull, Glynda, and Mike Rose. "This Wooden Shack Place': The Logic of an Unconventional Reading." College Composition and Communication 41 (1990): 287-98.

Lees, Elaine O. "The Exceptable Way of the Society: Stanley Fish's Theory of Reading and the Task of the Teacher of Editing." Reclaiming Pedagogy: The Rhetoric of the Classroom. Ed. Patricia Donahue and Ellen Quandahl. Carbondale: Southern Illinois UP, 1989. 144-63.

Lu, Min-Zhan. "Professing Multiculturalism: The Politics of Style in the Contact Zone." Horner and Lu 166-90.

- - . "The Vitality of the Ungrateful Receiver: Making Giving Mutual between Composition and Postcolonial Studies." J AC: A Journal of Composition Theory 19 (1999): 335-58. 
Lunsford, Andrea. "Toward a Mestiza Rhetoric: Gloria Anzaldúa on Composition and Postcoloniality." Lunsford and Ouzgane 1-28. Lunsford, Andrea, and Lahoucine Ouzgane, eds. Exploring Borderlands: Postcolonial and Composition Studies JAC: A Journal of Composition Theory (Special Issue) 18 (1998).

Schwalm, David E. "Degree of Difficulty in Basic Writing Courses: Insights from the Oral Proficiency Interview Testing Program." College English 47 (1985): 629-40.

Shaughnessy, Mina P. Errors and Expectations: A Guide for the Teacher of Basic Writing. New York: Oxford UP, 1977.

Soliday, Mary. "Class Dismissed." College English 61 (1999): 731-41.

- -. "Translating Self and Difference through Literacy Narratives." College English 56 (1994): 511-26.

Sternglass, Marilyn S. Time to Know Them: A Longitudinal Study of Writing and Learning at the College Level. Mahwah, NJ: Erlbaum, 1997.

Thompson, Karen. "The Ultimate Working Condition: Knowing Whether You Have a Job or Not." CCC Forum Winter 1998: A1924.

Tricomi, Elizabeth Taylor. “Krashen's Second-Language Acquisition Theory and the Teaching of Edited American English." Journal of Basic Writing 5.2 (Fall 1986): 59-69.

Villanueva, Victor, Jr. Bootstraps: From an American Academic of Color. Urbana, IL: National Council of Teachers of English 1993.

Wall, Susan V. "Writing, Reading and Authority: A Case Study." Bartholomae and Petrosky 105-36.

Wallace, David L., and Annissa Bell. "Being Black at a Predominantly White University." College English 61 (1999): 307-27. 


\title{
Susan Miller
}

\section{A FUTURE FOR THE VANISHING PRESENT: NEW WORK FOR BASIC WRITING}

\begin{abstract}
Current external and internal attacks on Basic Writing are in a metonymic relation to the entire field of composition studies, and thus bring up a number of justifiable concerns: original warrants for establishing the field are losing credibility; its sites are moving physically and being critiqued by its leaders, who question the motives, theories and the social results of curricula; its practices have become representations of a "new capitalism" that improves status and work for only a few, meanwhile inadvertently helping to disemploy many teachers. New "recognition work" is needed, directed at acknowledging anxieties about class status among composition professionals, which are projected onto students and divert the field from commitments to teach writing and research relations among writers, texts, and instruction. Developing the capacity to see local communities not as places to which composition might export its beneficence, but as the places whose interests and practices it shares, would create a new root metaphor for the field. The article exemplifies this possibility, describing sites whose origins and successful practices depend on averting the academic gaze on local constituencies in favor of taking on cooperative, interdependent projects.
\end{abstract}

I'm reluctant to project a future for BW just now because many current disagreements in the field suggest that to project new goals is to have joined a debate. Like the strident claims about classroom practices in composition teaching after James Berlin asserted and Maxine Hairston criticized "ideology" as the field's content in 1988-94 (Berlin, 1988, 1989; Hairston, 1991, 1994), current arguments recast the field's assumed goals. Those root metaphors have long been taken to represent it as stable, certainly professionalized, and heavily invested in the future of its students as well as in academic progressivism. But new disagreement is not so focused on a shared subtext as was the Berlin/ Hairston contest, nor is the field undergoing a broad paradigm shift that will end with unity about new course content, teaching methods, or assessment tools that, at last, fit our aims. Even were the academic

Susan Miller is Professor of English and Writing at the University of Utah. She teaches writing, rhetorical and composition theory, cultural studies, and literacy studies. She has directed writing at Ohio State, the University of Wisconsin-Milwaukee, and was founding director of Utah's University Writing Program. She has written Assuming the Positions: Cultural Pedagogy and the Politics of Ordinary Writing (1997), Textual Carnivals: The Politics of Composition (1993), Rescuing the Subject: A Critical Introduction to Rhetoric and the Writer (1989), and Written Worlds (1993).

() Joumal of Basic Writing, Vol. 19, No. 1, 2000 
success of inexperienced adults abandoned as the field's master trope, we would place quotation marks around any "new paradigm." I want to suggest instead that we face a post-paradigmatic future, one that assumes we can accept the naiveté of identifying an emerging contour as a settled "change," not as an intensification among already available ways of thinking and talking about any subject.

Nonetheless, there is important disagreement about the destinations of the paths we are on and of those we might follow. Only recently have public and academic attention to BW been simultaneously charged with defense OR critique, support OR attack. People dispute BW curricula, its appropriate pedagogies, its depiction of its students, funding and its curtailments, possible uses of technology in its classes. Most important, they question even the existence of the BW classes and students that David Bartholomae identified in 1993 as "expressions of our desire to produce basic writers" (my emphasis, 8), a definition that Ira Shor now intensifies by calling for an end to the BW "empire" ("Apartheid" 95). BW's histories and pedagogy have always been characterized by advocacy. But not until recently have public actions and academic conversations been so vividly strident and polemical. Consequently, it may be useful to explore why advocacy appears to be exhausted, at least as a unifying stance within the field. BW now appears to function as an academic instrument in a rephrased social agenda that may call "irrelevance" a virtue, a condition of articulation in the face of the vanishing present.

\section{The Vanishing Present}

It is easy enough to explain BW's bi-polar polemics as a product of material circumstances. The apparent devastation of its programs in New York, California, Texas, Florida, Georgia and elsewhere regularly mandates collective defensiveness. As Harvey Wiener points out in "The Attack on Basic Writing - And After," changes imposed in New York and many other settings will not abolish BW outright, but remake BW's self-identity. As he says, classroom spaces will rely increasingly on electronic systems whose physical presence may interrogate the immediate interpersonal exchanges that characterize BW pedagogy. Two-year colleges will provide more BW instruction, thus channeling many students away from continuous 4-year-college careers and severing the purposes of research in institutions that support it from the results of training in those that do not. No matter how excellent this instruction is, its isolation from other academic practices almost guarantees that its initially under-prepared students will, over time, remain in subaltern jobs. In addition, teachers will be excluded from the faculty bodies who govern their institutions. They will not, therefore, con- 
trol curricula, class size and other substantive matters. Privatized sites of instruction like the Sylvan Learning System will offer preliminary skills instruction, denying to many programs coherently sequenced goals and to many students an initiative exposure to the situated nature of what it means to write. And support will more often depend on positivist interpretations of empirical data, the "results" that have little to do with studies of changes in texts (Wiener, 100-102).

The plans that make Wiener's predictions plausible emerge in criticisms of specific sites of BW, which devalue universal access to protracted academic careers. Teachers, administrators, and researchers often one-in-the-same - in the early 4-year sites of BW find themselves as disempowered as they once thought only these students were. Consequently, they highlight past achievements without reimagining the specific relationships that define a "higher" education. Increasingly, they are not confident of sharing the cultural capital of accomplished education, which Irving Howe's, Alice Trillin's, and many other friendships with a relatively self-reliant Mina Shaughnessy brought to early BW programs (Maher, 143m $236 \mathrm{ff}$.).

The changes Wiener projects will also shorten the time and reduce the funding needed to achieve academic equity for BW. Material deprivation mutes expertise. It suppresses motives to reflect on exchanges among instruction, student texts and student comfort in mainstream classrooms and cultures. Too often, those triangular links now appear only on margins around otherwise well-documented defenses of BW programs, like Baker and Jolly's "The Hard Evidence." And thus effectiveness, upheld in retention rates, student progress, grade point averages, and completion of later writing courses is less frequently analyzed or thought of as a function of expertise about writing and writers. But as Marilyn Sternglass's Time to Know Them and Wiener himself point out, this research is necessary to maintain the academic status of BW.

Status is controlling BW's future in specific ways. At least contemporary theoretical, post-process narratives like Thomas Kent's tell us "the writing act is public, thoroughly hermeneutic, and always situated and therefore cannot be reduced to a generalizable process" (5). This claim suggests that BW's future will most likely be characterized by increasingly infrequent encounters with basic, or any, student writers. Following Kent, their writing is easily abandoned as impossible to control, at least by teachers swayed by this post-process "hermeneutic dance that moves to the music of our situatedness," which "cannot be choreographed in any meaningful way" (5). In such a context, no one can assume that the field will renovate its collective ability to identify with those we teach.

In support of this claim, it is important to note that critiques of BW galvanized by material circumstances outside the academy are 
more than matched in energy by this and other theories that axiomatically criticize the underpinnings of BW. Highly regarded scholars like Bartholomae, Shor, Min-Zhan Lu, Sharon Crowley and Bruce Horner participate, if in very different ways, in such theoretical dismantling of BW. New theory detaches itself, and composition, from acts of writing. These and other commentators describe BW and introductory instruction as inaccurately devised, or attempt to expose its politically motivated destructive social practices. Of course equally regarded scholars like Sternglass, Karen Greenberg, Terence Collins, Jeanne Gunner and Laura Gray-Rosendale are compelled to defend BW and its earliest discourses in counter-attacks. Formerly, these newly polemical edges on BW and all composition publications might have been blunted in close analyses that value practice according to the quality of its fit to discourse theories represented by socialist, postcolonial, linguistic, pedagogic and cultural theories. But in these and many other arguments, data and analyses fortify competing theses almost as often as they lead to them. It is thus fair to ask if something has gone wrong in the capacity of the field's root metaphors to maintain permeable, flexible boundaries around composition studies, and specifically around the BW that is always a metonym for it (see Rescuing 163-70).

This weakening of assumptions that have connected BW's warrants to its claims is exemplified in the rhetorical operations of the most recent winners of the Mina Shaughnessy/MLA book award. Sternglass's Time to Know Them and Crowley's Composition in the University assuredly further the goals that the prize symbolizes. But each advocates what are easily read as diametrically opposed views. In Sternglass's account, first year composition appropriately begins students' longitudinal development. It is a course that integrates critical reading with analytical writing based on evidence rather than examples (297-98). In Crowley's, "the required introductory course . . . as an institutional practice, has no content aside from its disciplining function" (10). It is of course possible to conflate these arguments by claiming that Crowley's elective vertical curriculum matches Sternglass's copious horizontal and vertical one. Nonetheless, markedly different subject positions must be assumed by cooperative readers of these texts. Sternglass's accepting reader appreciates pleas for increased institutional attention to developing sites of instruction, including provision of tutorials for inexperienced writers, while Crowley's consenting interpreter can agree that initiative instruction is a "hurdle" (244). Both readers, like these writers, in some measure expect empirical data and theorized analyses to verify some already normalized political positions, not to produce novel interpretative frameworks. Both also necessarily imagine any future for BW occupying contested terrain. Even omitting a close analysis of Ira Shor's direct labeling of BW as a form of "apartheid," it is obvious that the field readily debates the value of 
adding, even maintaining, current sites of generic writing instruction for "novice writers" (Dickson, qt. in Sternglass, 5).

These and other examples do not oppose excellent, even improved instruction or predictably better transitions from preparation to advanced college courses. Instead, it first appears that what is in dispute is the nature and governance of sites of any writing instruction. Scenes of teaching focus these arguments, not just in the attacks that appear to be motivated only from outside the academy but in discussions of value among academic conversants. Even Shor and many others who do not stress doubts about where and under what requirements inexperienced writers should study nonetheless articulate their concerns in spatial figures. For example, Horner and Lu's Representing the "Other": Basic Writers and the Teaching of Basic Writing represents "levels of schooling and non-institutional sites of literacy learning" as "zones" that characterize relations between BW and literacy, between BW and globalization, between BW and history (my emphasis, 205). As Horner says elsewhere, "the success of BW in legitimizing the institutional place of basic writing courses and students cannot be separated from [how] it works within the framework of public discourse on higher education" (my emphasis, 200). Christie Friend pointedly asks, "What kind of public space is the writing classroom? What kind should it be?" (658). Myriad recent examples like Gesa Kirsch's Ethical Dilemmas in Feminist Research: The Politics of Location reinforce this hypothesis: The "dilemmas" throughout the field are portrayed in spatial images, as are extra-academic criticisms directed at the feasibility, or lack of it, of actual instructional locales.

But address to internal and external anxieties about place is regularly oversimplified. It is not news, that is, that education always represents a spatial determinism that superimposes material on ideological forces and the reverse. In the United States, establishing educational institutions is equated with school-building/s, the cost, location and architectural style of which demonstrate local politics and its stratification of various constituencies. Education is also theorized precisely as a space. Debates about the relative quality of public, private and especially home schooling always allude to instructional settings, just as frequent analyses of classroom seating and teacherly "positions" are commonplace evidence in pedagogic theory. New places for teaching - a computer lab, a for-profit skills center-and Shor's imposition of the allegory of race-based quarantine on BW's goals - equally characterize norms whose locations appear to be at issue.

The current BW imaginary, that is, is now very uneasy about once upright towers of institutional power and production that I and many other early proponents of Open Admissions readily climbed to initiate new, additional, required, credited BW instruction that we expected to raise academic/cultural capital for abstract but nonetheless indi- 
vidualized "students." Teaching behind closed doors that privatized classrooms, in carefully delineated Departments of English or in partially furnished subterranean Writing Programs, we offered formerly unlikely graduates experience in the isolated writing practices whose mastery informed our own value/s (see Horner, 200). Above all, we prized singular interpretation, yet distributed it across genres like narrative and documented essays, which we valued for their one-two imitations of literary writing and academic research. Our preparatory programs also fostered a "joy of language," a somewhat mysteriously presented appreciation of the humanistic universals of Hugh Blair's "Taste."

The subtexts of these "new" BW pedagogies were, that is, not at all new. They remembered time-worn mechanisms for reproducing privilege and hegemony, commonplaces that highlighted our own tolerance, not methods that would show new students how to affiliate with established elites. We fostered assimilation into a social role or vocation by teaching a personal transparency penned in process of thinking "for yourself." But we easily balanced these competing goals of socialization and individuation, domestication and emancipation, resolving their obvious conflicts as the inevitable attributes of an "educated public." That imagined personality would discuss its "self" versus "public interest," thereby enabling a civic discourse across various spheres of life. These quasi-personalized pedagogic spaces simultaneously housed a presumably individual student "disposition" and imposed its universalized expectations.

In addition, these symbolic spaces equally assigned teachers and students relations of age- and knowledge-dependency. Teachers held the acceptable individual and social meanings recognized in sanctioned structures of feeling and orientations toward authority. The classroom was (and unfortunately is still) idealized as an Oedipal scene. In it, even newly prevailing agendas for gender relations and agency become legible only when written on such domestic subtexts of pedagogy. As I've suggested elsewhere, this material/theoretical space of institutional writing is infantilized by a mother/teacher. But by idealizing the content of individualism/public interest, BW classes simultaneously promise access to a public standing that depends on access to, yet check by, fatherly authority. Students and teachers in this situation were imagined to enact, and then continuously reenact, a constitutive, constricting ambivalence about authority, without resolving that contradiction in signifying actions (Miller, Carnivals 134-38; Trimbur "In Loco").

Today's polemical discussions around whether and "where" to teach BW still install that ambivalence. But a new incongruity is also vivid. The "old [pedagogic] capitalism" I've just described is now overlaid on a contemporary turn to the social, exemplified by current theo- 
ries of epistemology, language theory and collaborative pedagogy, and the ideological analysis of literacy in Brian Street's Literacy in Theory and Practice. As James Paul Gee says in "The New Literacy Studies: From 'Socially Situated' to the Work of the Social," a "new capitalism" arises from such turns to the "social." This formation demonstrates that little connects constructivism to social progressivism. Instead of a new egalitarian politics, we see global connections between wealth and a self-defined group of technologically-linked symbol analysts. They produce new knowledge and hereby create themselves as a new class that is demarcated as a class only by its simultaneous affiliations to wealth and knowledge, not by its own status. In addition, this corporate social construction includes members of new teams, the enchanted workers who add value to production when their dedication to projects results in their presence at creations of new knowledge. But the service workers outside are neither wealthy, symbol analysts, nor enchanted insiders. They are not at home in the necessarily circumscribed team command centers on which this sociable capitalism depends. This group, who some project to be two-fifths of the employable, will with difficulty find any work at all (188).

This explanation immediately recalls the computer industry, whose enchanted workers increasingly notice their only-adequate compensation for limitless hours spent pursuing "performance excellence" (see Hayes; Gee, 189). But it also glosses the ambivalence of the energetic yet conflicted contention around BW. Those contests, that is, arise from a realization that socially turned composition studies has not realized egalitarian agendas. This disappointment is realized as the field's professional parallels with new capitalism become increasingly clear: theorists and administrators (symbol analysts) affiliate with faculty members who teach writing, other secure teachers and temporary teams of graduate assistants. With these enchanted workers, those connected to institutional wealth by hard-won disciplinary respect and governance powers fabricate knowledge-producing, value-adding writing curricula ("projects"). These socially turned insiders enact the new composition whose status rose, in fact, largely from successes gained from Shaughnessy's justifiably powerful reputation on the old capitalist market. But as they attempt to affiliate with that power while maintaining a supposed new ethic, these new insiders take up causes fraught with contradictions. In sum, their projects actually mourn the social turn's increasingly visible failure to enhance social progressivism.

For instance, in this situation, we can consider doing away with requirements, either by "mainstreaming" BW students or by providing for them composition courses only as part of an array of electives. Either tactic obviously undermines the inauguration of BW to create additional sites of writing instruction to supplement already grudgingly provided FY courses, which have been generously tolerated in the acad- 
emy only because they are mandatory. Either project would lift the status of many, including some students. But new-capitalist elevations of symbol analysts and enchanted workers can already be seen to disemploy and render ancillary dedicated BW teachers who were once integrated into 4-year institutions. Gee's projected two-fifths of employable people are here represented by former graduate-student team members and many who were unofficially but customarily secure adjunct instructors. Doing away with the requirements that sustained them, no matter for what motive, will undermine the prestige of the field's original dedication to help beginning students and simultaneously remove some teachers entirely.

In composition and BW, then, faculty members who are totally committed to introductory courses and their value-adding contributions do shore up the projects of their collaborative teams. New capitalism expects these dedicated professionals to make knowledge, affiliate with theory, become entrepreneurs of credit hours and friends of legislators. But the value produced by graduate-level teaching, electronic know-how, juried publications and administrative power, new measures of socialized economic productivity, ironically excludes much of the teaching undertaken outside these lines. Old capitalism, that is, recognized those irregularly assigned to teach its independent yet publicly invested student writing. But new capitalism may require that such outsiders resign unprofessional desires to teach the attractive but professionally "useless" initiative classes where they could engage in "assessing human worth, status, and community outside of financial rewards and markets ..." (Gee, 189).

\section{The New Work}

I've outlined here external attacks on the sites of BW that may result in the changes Wiener predicts, as well as internal contests over the value of $\mathrm{BW}$, and their implications in two cultural models, old and new capitalism, which appear to be breaking down with equally destabilizing effects. This sketch may appear to describe a one-two punch to BW: material and theoretical displeasure aimed to destroy its habitas. But that inference does not reveal that it is interactions among academic and extra-institutional agendas, not their separate operations, that now rearrange its sites. Together, the workings of society and the academy move BW to high school, two-year, and private places of instruction, leaving more prestigious intellectual leadership within a new capitalist configuration. So BW, having successfully established and given credibility to its sites over the last twenty-five years, now paradoxically takes up the project of eliminating its practices. In the name of the new capitalism's emphases on expertise and knowledge-mak- 
ing, that is, BW (and certainly all of composition studies) is ripe both for both old and new arguments against writing instruction. Old arguments had already dismissed its intellectual interest in non-canonical writing; new ones say it is neither well-grounded in a theory nor socially responsible.

In this unfortunate situation, the academy can simultaneously condemn attacks on entry-level programs by a legislature, insist that writing teachers are exploited and argue that composition professionals are too valuable to teach writing classes. Enchanted workers can realize that personal value in curricular laboratories, by supervising service-worker teachers who may have ample experience and long personal histories of successful teaching, but not the time to read and write themselves into enchantment. In effect, professionalized sites of BW, insofar as they are preserved at all, can easily parody themselves, becoming Pickwickian, two-dimensional allusions to involvement in student writing and the changes instruction makes in student texts. A good example of such a parody of substantial attention to writing occurs in prominent emphases on the "identity" of students. Tangible local adult BW students in such programs can be safely exoticized, assigned to categories that skirt their lower middle-class status and their familiar attachments. Negative conversations about students do portray novice writers as members of that discomfiting petit bourgeois, the lower middle-class that scholarly writing presents "as provincial, narrow-minded, even racist," but not as a now-fashionable hybrid (Felski, 42).

This class has "nothing to declare," no characteristic public discourse, no matter how fragmented, that is digested by symbol analysts on its own terms (Felski, 43). Its members may be nominally assimilated to a middle-class status they can appear to share with their selfdeclared middle-class teachers. Or, they may be identified by various theories of identity politics that replace studies of discourse, language, and rhetorical invention, arrangement or style - the instruction long preserved for powerful elites but denied to this class. In this process, female experience and sexuality become known as "gender," ethnicity becomes an immigrant's deficit, and contemporary African Americans of any history stand in for ex-slaves. In almost desperate attempts to stay untainted by ordinary non-prestigious groups, this process of avoidance even subsumes the usually unmarked category of white males under faulty/false consciousness. We cannot, of course, discount parallel discrepancies between the actual identities of teachers and parodic two-dimensional possibilities. They may share the origins and tastes of their students, the same popular diets, sports, music and movies, but nonetheless conceive of the students they might discuss them with as deprived of cultural advantages and political sophistication.

A commitment to forego such defenses against this least power- 
ful but evidently most threatening class would provide a way to step outside such productions of a pedagogic habitas based on avoidance. Evasion is not necessarily a permanent nor even temporarily logical way to handle emerging conditions around BW and composition studies. Nor will it protect our new capitalist identities as symbol analysts and enchanted workers whose prestige is based on affiliations, not intrinsic or inherited qualities. To forgo this avoidance would primarily mean acknowledging the only partial access and always provisional inclusion in established traditions that is represented by the ambivalent status of two-year colleges, computerized classrooms and respectable middle-class liberalism. While it is no wonder that thoughtful theorists suspect apartheid and coercion, they might also note the growing number of vivid examples of those who do accomplish equality among constituencies. This is not to say, of course, that relatively open frameworks for academic action are purely intended or absolutely realized. It is to emphasize that the righteousness of both old and new forms of academic superiority needs testing, not just commitment to either selfannihilation or to holding the earliest BW forts. We should hope for more than shifted discourses in stable sites.

Gee suggests the alternative work on which we might focus, an engagement in what he calls "recognition work" that undertakes the on-going task of getting a "set of people, deeds, words, settings, and things recognised[sic] as a particular configuration with each of its members recognised[sic] in a certain way" (Gee, 189). This "work" would allow institutions to recognize unprepared students in ways most beneficial to their academic progress and most likely to encourage their recognition of and work to foster conditions that protect and enlarge the scope of the academy. But such mutuality necessarily dissipates if academics fear a petit bourgeois and therefore portray students as surprisingly "interesting" recipients of know-how and empathy, not as new constituencies in schooling. As recipients only, that is, the communities around writing programs see clearly that "the public face of the humanities ... is deeply disdainful of petit bourgeois values. ... [T] he intelligentsia may choose to align itself with the culture of the most oppressed but must constantly [also] differentiate itself from the culture closest to it" (41). In sum, universities and those who want to thrive within them have normally viewed Hegelian disembodied intellectual purity as a form of superior cultural status. They do not see it as the simple condition of adventuresome intellectual speculation and experimentation. But this self-isolating celebrity is now ignored by its former audience, which is currently constructed as essentially different from many who claim to prepare it to live well, not to write its own immediately situated social and professional stories. Students, not their preparation for such actions, hereby become the content of our courses. 
I am obviously not alone in imagining alternative work within this goal for BW (see, e.g., Grego and Thompson; Gere, "Kitchen Tables"; Herzberg). Yet I want to focus the project of "getting to recognize" as an alternative to prevailing "import/export" models that alienate BW, composition studies, and the academic "estate" from their own human and geographic contexts. It is possible, that is, to counteract the recipient/patron model that imports and exports symbolize, by imagining and helping to create differently represented places that encourage language alliances in projects undertaken by mingled students, their home communities, the institutions they enter, and the cultural and social interests to which they continuously return. Such places do not privilege but are aware of expertise; they count its worth in contributions to community-building, not in credit hours, research data, or grateful admiration. They may enable linguistic transitions out of familiar settings. But they more importantly join familiar and unfamiliar existing social texts, within which movement "out" is not necessarily a goal. They highlight mutual interests that are embodied encounters among indigenous professional, social, and academic literacies that are already performed.

Certainly traditional institutionalized programs that appear to undertake this recognition work do not in fact take their missions to be establishing mutually managed and productive curiosity that can set aside academic and community awkwardness about class, gender and race identities. They may acknowledge very specific local foundations on which writing and reading stand. But these foundations are not necessarily highlighted in the many admirable and multiplying service learning courses nor the proactive promotion of "intercultural discourse" represented by Pittsburgh's Community Literacy Center and others like it. For all their precocious sense that universities are in communities, such outreach projects only slowly, and as yet not very effectively, set aside their export models. Few can take for granted, not exoticize, the important religious, work-related, political and social affiliations that comprise the elements of student and faculty lives.

Nonetheless, students at any "level" are closely affiliated with their families. They remain involved in local churches and high-school friendships, and engage in familiar literacy practices like those that have always contributed to, if not constituted, particular emphases in local academic sites. As yet, however, the many academic initiatives toward cooperation have done little to create conditions that require mutuality, nor have they been intended to do so. Diversity, preparatory academic courses, targeted financial support, dedicated old ornew capitalist teaching, and address to consciousness through imported critical pedagogy have all been delivered to local constituencies. BW teachers take it as a principle that students and their language might "change." But they do not readily accept that whatever their class, stu- 
dents are like history: they accumulate identities and terministic screens. As do their teachers, they move among variable positions and discourses according to the situations, not the cultural absolutes and privileges, which they perceive to be pertinent.

The most salient characteristic of the spaces of recognition I am imagining is precisely this premeditated purpose, to join active interests in a locale to create various mutual, not "service," projects. Certainly the academy's acquisition of students and their credit-based tuition, of funding, and of community advisors and recognition remains important. So also does the export from the academy of prestige, expertise, applied research benefits, and political and civic participation. But a differently realized desire for mutuality finds similarities, not oppositions, in schooled and unschooled groups. It defines not the category of "student" but various productive relationships with the writing, reading, discourses and communications regularly engaged by and around any participant. Such programs should ease recursive movement into and out of schooled standing. But as of yet, the academy's participants have done little to address their class-based ignorance of other indigenous literate practices or of the pragmatic structures they manifest.

Many reports and proposals over the last decade highlight the possibility of this form of recognition work within an expanding mission for post-secondary education, which must increasingly connect its teaching and research to the day-to-day lives of the fluid local publics around it. Not just financial survival, but the ability to compete with rival educational sites depends on it. This emerging contour is palpable in enforced movements of writing curricula from one to another institution in public systems, as I've said. But it also shows itself in positive steps like those of the Kellogg Foundation, whose higher education funding initiatives include "increasing access and academic achievement for underrepresented students," "institutional transformation and change" and "linking the intellectual resources of colleges and universities to community needs" (Kellogg initiatives).

These abstractions, which still retain import/export overtones, nonetheless offer commonplaces with which to invent diverse sites that might assure the recognition of existing and developing literate practices in any community. They make it possible to portray these practices as normal ways of testing and forming identities within circulating discourses. These practices include the "creative" and "artistic" along with those undertaken by children and other age-related or special interest collectives. They include expressions and communications that may be collectively performed, showcased, and shared across class and neighborhood boundaries under the auspices of sites we can help create. As my context for this proposal already demonstrates, academics participate in such interactions with difficulty. They are often un- 
comfortable when situated realities require them to avert the gaze of their conventional subject position in favor of more convergent goals, such as mutual understanding, conjoint teaching, and cross-class sharing. Lines drawn by old and new educational capitalism now surround all of composition studies. But a different, community-oriented aspect might see stories and plots, proposals and advocacy, diaries and family histories, and the manifestos of diverse groups without taking up mandatory enrollment, damaging stratification and even characteristic local insistence on the prestige of high-cultural displays.

Unless one is already engaged in ethnographic indexing of indigenous writing practices (e.g., Pimentel), it is difficult to accept that unrecognized yet persisting literate production regularly occurs outside schooling. Reading groups are now well publicized, not only by historical exposition like Ann Gere's Intimate Practices, but by the power of Oprah Winfrey's book lists. But few professionals accept that writing groups also regularly gather, for recreational and for-profit writing of not only fiction, but memoirs, diaries, family histories, and special-interest proposals that address youth and aging, housing, schooling, the homeless and other civic concerns. Existing sites include the national Community Writers Association; the Lake Superior Writers Community Outreach (which offers a Creative Prose Group, a Memoir Writing Critique Group, and a Fiction Writing Critique Group); and the Boise, Idaho, Log Cabin writing center, which holds weekly meetings about such topics as "Developing the Habits of a Writer who Actually Writes" and "Copperplate Calligraphy," and which sponsors a summer camp for young writers funded by a local law firm and the Idaho Arts Council (Log Cabin Projects).

Individual academics already participate in similar undertakings among local groups who may not feel entitled to such "hobby writing," as many also volunteer in literacy action centers. But such action does not enact the embeddedness in local physical and ideological space that new recognition work highlights. Few with academic standing who are not "creative writers" have conceived or led such projects, undertaken with, not about, such local interests. Such a project is exemplified, however, in Salt Lake City, where a non-profit community development corporation, Artspace, houses inexpensive children's summer writing programs that are staffed not by expert professional writers or researchers, but by mothers and community-college faculty members. They meet in a strategically chosen, socially equivocal location that is convenient to the neighborhoods, poor and posh, whose children participate.

Another site that exemplifies the work for BW that I am projecting is in an urban Salt Lake City high school. It was jointly conceived by the school's teachers, faculty members, English Education majors and members of the families of students. The West High School/Univer- 
sity of Utah Family Literacy Center now thrives after a year of the work that I am appropriating from Gee's nomenclature. Weekly, it receives numerous requests to join with local service organizations and with other school districts and post-secondary institutions. The key to this success is not only the energy of teachers in the school, of English Education faculty members and of the families and students who participate. It is recognition among all who are invested in this setting that schooling is only a very small part of the (often happily) unassimilated students' indigenous support systems - their family, church, work, club, even gang affiliations. (See Kaufman; Lane)

Schooling may withhold comfort and growth in favor of judgment and stalled promises when it does not recognize those who are not already comfortable among its discourses. But schooling recognizes only with difficulty that those outside its habits of thinking and talking are precisely, and only, that: those without experiences that fluently connect their home/civic worlds to alien, often physically distant, imposing post-secondary settings. This axiom is often asserted in research into literacy and its teaching. But that research rarely takes up the partial quality of schooled literacy experiences, which contribute to deeply grounded structures of feeling, but do not control them. Those structures do not, in fact, always foreground conflict, deprivation or the outsider status projected by many within the academy, even when our firmly positioned observations persuade us they do. Suspending such conventional hierarchies of knowledge and comfort among academic and extra-academy interests might invent more useful and more accurately ambiguous spaces like those I've sketched here.

As I acknowledged early on, I realize how irrelevant this suggestion about a future for BW may appear in light of contingencies that intrude on any such hope. But unfortunate belief systems are the most common obstacles to this recognition work and other ways of reimagining preparation as local places, not as social and institutional placements. Those now celebrating the new capitalism deploy belief systems that extend the privileges of equally competitive precedents. They contend and criticize within and outside BW, often covertly appreciating most the social turn's ability to categorize groups while appearing to create a falsely participatory professional atmosphere in which reading and writing are nonetheless specializations. But these limits, hard-won professional categories that appear now to be placemarkers in a vanishing present, do not allow BW and all composition studies to identify with the rich interests and extant, already active linguistic cultures of those they claim to improve, but cannot easily join. 


\section{Note}

The title alludes to Spivak's $A$ Critique of Postcolonial Reason: Toward A History of the Vanishing Present.

\section{Works Cited}

Baker, Tracey and Peggy Jolly, "The 'Hard Evidence': Documenting the Effectiveness of a Basic Writing Program," JBW18.1 (1999): 2754.

Bartholomae, David. "The Tidy House: Basic Writing in the American Curriculum." JBW12.1 (1993): 4-21.

Berlin, James. "Rhetoric and Ideology in the Writing Class." College English 50 (1988): 477-494.

-. "James Berlin Responds. 'Rhetoric and Ideology in the Writing Class.' " College English 51 (1989): 770-77.

Collins, Terence G. "Responds to Ira Shor," JBW, 216.2 (1997), 95-100.

Crowley, Sharon. Composition in the University: Historical and Polemical Essays. Pittsburgh: U of Pittsburgh Press, 1999.

Dickson, Marcia. It's Not Like That Here: Teaching Academic Writing and Reading to Novice Writers. Portsmouth, NH: Boynton/CookHeinemann, 1995.

Felski, Rita. "Nothing to Declare: Identity, Shame, and the Lower Middle Class," PMLA 15.1 (2000): 33-45.

Friend, Christy. "From the Contact Zone to the City: Iris Marion Young and Composition Theory," Journal of Advanced Composition 19.4 (1999), 657-76.

Gee, James Paul. "The New Literacy Studies: From 'Socially Situated' to the Work of the Social," in Situated Literacies: Reading and Writing in Context. Ed David Barton, Mary Hamilton, Roz Ivanic. London \& NY: Routledge, 2000.

Gere, Anne Ruggles. "Kitchen Tables and Rented Rooms: The Extracurriculum of Composition," College Composition and Communication 45.1 (1994): 75-92.

-. Intimate Practices: Literacy and Cultural Work in U.S. Women's Clubs, 1880-1920. Urbana and Chicago: U of Illinois P, 1997.

Gray-Rosendale, Laura. "Inessential Writings: Shaughnessy's Legacy in a Socially Constructed Landscape," JBW17, 2 (1998): 43-75.

Greenberg, Karen. "Responds to Ira Shor," JBW216.2 (1997), 90-4.

Gunner, Jeanne. "Iconic Discourse: The Troubling Legacy of Mina Shaughnessy," JBW17.2 (1998), 25-42.

Hairston, Maxine. "Diversity, Ideology, and Teaching Writing." College Composition and Communication 42.2 (1994): 179-193.

-. "Required Courses Should Not Focus on Politically Charged Social 
Issues." Chronicle of Higher Education 23 (January, 1991): B1 and B2. Herzberg, Bruce. "Community Service and Critical Teaching." College Composition and Communication 45.3 (1994): 307-19.

Horner, Bruce. "Discoursing Basic Writing," College Composition and Communication 47.2 (1996): 199-222.

Horner, Bruce and Min-Zhan Lu. Representing the "Other": Basic Writers and the Teaching of Basic Writing. Urbana, IL: NCTE, 1999.

Idaho Log Cabin, http://www.logcablit.org/cabhap2.html\#February. Kaufman, Janet. "The Family Literacy Center: Community Partnership in English Education." Article in preparation.

Kellogg Foundation Initiatives for Higher Education, http:/ / www.WKKF/org/.

Kent, Thomas, ed. Post-Process Theory: Beyond the Writing-Process Paradigm. Carbondale, IL: Southern Illinois University Press, 1999.

Kirsch, Gesa. Ethical Dilemmas in Feminist Research: The Politics of Location. Albany: SUNY Press, 1999.

Lane, Rich. "Composition Live: Pedagogy in the Interactive Television Writing Classroom." 2000 CCCC presentation.

Maher, Jane. Mina P. Shaughnessy: Her Life and Work. Urbana,IL: NCTE, 1997.

Miller, Susan. Rescuing the Subject: A Critical Introduction to Rhetoric and the Writer. Carbondale, IL: Southern Illinois University Press, 1989.

-. Textual Carnivals: The Politics of Composition. Carbondale, IL: Southern Illinois University Press, 1991.

Pimentel, Ocatavio. “Borderland Literacy: Recognizing Non-Traditional Literacy Practices." Unpublished dissertation, University of Utah, 2000.

Shor, Ira. "Our Apartheid: Writing Instruction and Inequality." JBW 16.1 (1997): 91-104.

-. "Inequality (Still) Rules: Reply to Collins and Greenberg," JBW17.1 (1998): 104-9.

Spivak, Gayatri Chakravorty. A Critique of Postcolonial Reason: Toward A History of the Vanishing Present. Cambridge, MA \& London: Harvard University Press, 1999.

Sternglass, Marilyn S. Time to Know Them: A Longitudinal Study of Writing and Learning at the College Level. Mahwah, NJ: Lawrence Erlbaum, 1997.

Street, Brian. Literacy in Theory and Practice. New York: Cambridge University Press, 1985.

Trimbur, John. "Taking the Social Turn: Teaching Writing Post-Process." College Composition and Communication 45.1 (1994): 108-118.

-. "In Loco Parentis: Teacher's Authority in the Writing Classroom," Journal of Advanced Composition 15.2 (1995) 309-11.

Wiener, Harvey S. "The Attack on Basic Writing-And After," JBW 17.1 (1998): 96-103. 


\title{
Deborah Mutnick
}

\section{THE STRATEGIC VALUE OF BASIC WRITING: AN ANALYSIS OF THE CURRENT MOMENT}

\begin{abstract}
Viewed in the context of 1960 s mass movements that paved the way for an expansion of rights to women and minorities in particular, the development of academic support services like basic writing can be seen as a response to grassroots political struggles for social and economic justice. Although such services, along with affirmative action and open admissions policies, have benefited people of all backgrounds, it has been working-class African Americans, Latinos, and Native Americans for whom they opened the doors of higher education. Only if we understand basic writing instruction in this larger sociohistorical context can we make sense out of the confluence of conservative and scholarly assaults on it. The author stakes out a position for the strategic value of basic writing that underscores the need to defend it -and other hardwon rights to education - while acknowledging the importance of composition scholars' concerns about the dangers of tracking, stereotyping, and misrepresenting basic writers.
\end{abstract}

The weight of the SAT's has different effects on everyone. Some people are nervous and others are claim, but it all depends on how that student has prepared his her self. Garcia said "one Saturday morning squirming with the SAT's can cancel four years of hard work."

I agree with Scott King, for a lot of reason like one is he said can we expect a decent society is allowed to kill it's own people. To me that mean how can we listed and agree with people who kill other people.

In recent years there has been a dramatic shift in the way we, as a society, view competition. Nelson's argument on how men and women view competition cannot be more accurate. Her argument is not only visible throughout the media but seems to be growing in popularity as the years pass on. It seems men have clearly lost sight of competition as a way of becoming

Deborah Mutnick is an Associate Professor of English at Long Island University-Brooklyn, where she directed the Writing Program from 1992 to 1999. She is the author of Writing in an Alien World: Basic Writing and the Struggle for Equality in Higher Education, which won the W. Ross Winterowd Award for the most outstanding book in composition theory in 1998. In addition to basic writing, her research interests include autobiography studies, ethnographic educational research, and community literacy. 
closer to others and are instead focusing on the outcome rather than enjoying the process.

I begin with examples of student writing, not to affix labels to them but to ground my perspective on basic writing's role in higher education in actual texts. The passages are the first paragraphs of placement exams written by entering students at the Brooklyn campus of Long Island University. Our test requires students to read a short editorial and write an essay in which they take a position on a topic, explain the writer's argument, and go on to support their own argument with evidence and examples. ${ }^{1}$ If the third passage seems relatively clear-cut in terms of placement in freshman composition, the first and second raise key questions about college admission and what kind of instruction most benefits students with weak academic skills. Although the readers of the second passage failed the exam, ${ }^{2}$ such writing is familiar to most basic writing teachers, at least at urban, working-class institutions like LIU. Similarly, we would not be shocked to find writing of the sort produced in the first passage in a freshman composition class. The fluidity of our own categories results both from the subjective element in the evaluation of any piece of writing and the uneven performances of all writers.

But individual consciousness, as many theorists have pointed out, is shaped by the social and discursive worlds with which we interact. So for a moment let us imagine that the second passage failed because the writing's obvious weaknesses - a high degree of error, syntactic confusion, and lack of focus - resonate with several related but separate national trends that influenced the readers. At all levels of education, pre-K on up, there is a frenzied call for higher standards and more and more testing; at the college level, the rhetoric of standards has been used to promulgate anti-affirmative initiatives, end open admissions, and eliminate remedial programs. In my own department, there has been a frank, disconcerting discussion about the problem of admitting students like the writer of the second passage to the university.

The first passage, on the other hand, would be less likely to raise a red flag to readers - or the general public - because its weaknesses are better concealed. Fewer surface errors, the use of a quotation, and better syntactic control give this piece of writing a coherence that seems passable - at least, borderline - for an entering college student. Looked at more closely, however, the exam reflects the writer's weak reading skills and inability to grasp or develop an argument. Writing in response to a short editorial opposing reliance on SAT scores for the purposes of college admission, the writer rather poignantly misses the point, concluding, "Everyone has their own thoughts on how to get 
ready for a major exam, so I believe that what ever makes a person comfortable then that's how they should prepare themselves for what comes along with a failing or passing grade." By the same token, there is a glimmer of understanding in the response of the writer of the second passage to a different prompt, an editorial by Coretta Scott King opposing the death penalty. This writer states: "Another reason I agree is that Mr. King is right on is that the only way of stop violent is to practice nonviolence I think that one with work."

These writing samples demonstrate several issues I would like to put on the table: 1) the rhetorical and intepretive weaknesses of the writing deemed "basic" could be more difficult to address pedagogically than the error-ridden writing that failed; 2 ) the failed test, though by no means hopeless, does reflect complex writing problems that can be extremely daunting for teachers and students alike; 3 ) both passages suggest that the writers would need strong support to cope with the demands of college. ${ }^{3}$ Do we want to provide a sheltered place in the academy for these writers? Could they survive in a mainstream composition course or without any composition course at all? Should the writer of the failed passage have access to post-secondary education? And if so, in what sort of institution? Like Mina Shaughnessy, I believe that most so-called basic writers are educable; but I also know the frustrations and disappointments of students and teachers attempting to cultivate skills in a few short years that more privileged members of our society develop over a lifetime. To defend basic writing at present means contending both with conservatives who condemn us for allowing underprepared students through the doors of higher education in the first place and those in our own discipline who want to abolish remedial instruction because it stereotypes students and segregates them from the mainstream.

\section{Political Attacks on Basic Writing, Open Admissions, and} Affirmative Action

As those familiar with the history of composition know, it was at City College in the late 1960s that Shaughnessy and her colleagues developed a pedagogy called "basic writing" for students whom she describes as "true outsiders ... strangers in academia, unacquainted with the rules and rituals of college life" (2-3). Today, more than thirty years later, as legislators and boards of trustees across the country dismantle remedial programs in the name of raising standards, and composition scholars debate the pros and cons of basic writing, it seems increasingly important to remember that "basic writing" emerged at a particular historical moment. While Shaughnessy chose the term "basic" to avoid the pejorative connotations of "remedial" or "develop- 
mental," in retrospect we can see that the creation of basic writing at CUNY and elsewhere was a direct response to the struggle for open enrollment by and for working-class and poor students of color. ${ }^{4}$

The emergence of "basic" as opposed to "remedial" writing instruction - which arguably begins with the introduction of the firstyear composition course at Harvard - coincided with the expansion of higher education to nonwhite, working-class students, primarily African Americans, Latinos, and Native Americans. Such reforms in the 1960s were not isolated phenomena; they would have been impossible without the impetus of the mass movements for social change that swept the country. According to Frances Fox Piven and Richard A. Cloward in The Breaking of the American Compact, there were two brief periods in twentieth century American history during which substantial gains were won for the working class: the 1930s, in which the industrial workers' movement secured more benefits and rights for labor; and the 1960s, in which the civil rights movement expanded the social compact to groups that had previously been excluded from it. Viewed in this context, basic writing, for all its internal contradictions, has played a vital role in increasing access to higher education, in particular for working-class people of color.

Although white ethnic students were initially the main beneficiaries of open enrollment at City University, the far more salient fact is that the number of nonwhite students increased from four percent in 1969, before open admissions, to 65 percent in 1999 (Romer), by which point CUNY's enrollment of Black and Latino students was among the largest of any university in the country. It was a student strike on April 22,1969 , led by the Black and Puerto Rican Student Community, that forced the administration to acquiesce to the demand for open admissions and ensure that CUNY reflected the demographics of New York City high schools. One has only to read Adrienne Rich's eloquent testament to the political lessons of the early years of open enrollment to appreciate the exuberance with which she and other SEEK faculty embraced the radical objectives of the student movement. Rich, who applied to teach in the SEEK program out of "white liberal guilt," passionately describes the experience of white teachers whose "white liberal assumptions" were shaken by their confrontation at CUNY with "the bitter reality of Western racism" (57).

This moment of genuine political and academic reform was unfortunately short-lived. In a 1975 foreword to "Teaching Language in Open Admissions," Rich laments the reversal of open admissions that had already occurred since the essay's original publication in 1972:

... [T] he white faculty at least ... vastly underestimated the psychic depth and economic function of racism in the city and the nation, the power of the political machinery that could be 
'permissive' for a handful of years only to retrench, break promises, and betray, pitting black youth against Puerto Rican and Asian, poor ethnic students against students of color, in an absurd and tragic competition for resources which should have been open to all. (51-2)

That retrenchment resulted in the imposition of tuition after the city's fiscal crisis in 1975 and the reinstatement of admissions requirements "close to national norms" at the senior colleges (Wiesen Cook and Cooper). Last year, on January 25, culminating a political crusade led by Mayor Rudy Giuliani and Governor George Pataki, the New York Board of Regents voted to eliminate remedial programs from all eleven senior colleges, thus ending the era of open admissions as defined in 1970. Based on 1998 projections by CUNY, five of the eleven senior colleges will lose more than half their entering students as a result of the new admissions policy, which went into effect in the spring semester of 2000. Hardest hit will be minority students whose numbers in the senior colleges could be reduced by as much as 55 percent of Latinos, 51 percent of Asians, and 46 percent of African Americans, compared to 38 percent of white students (Arenson). ${ }^{5}$

According to Nancy Romer, a professor of psychology at Brooklyn College active in CUNY politics, the battle over open admissions is part of a global economic crisis that has yet to be felt in the United States. Contrasting news reports of recessions, mass unemployment, bank failures, and currency crises in countries like Russia, Japan, and Brazil with continued prosperity in Western Europe and the U.S., Romer concludes: "Despite a budget surplus in both the city and the state, New York political elites, viewing these ominous economic clouds on the horizon seized the moment to decrease the public domain while expanding opportunities for capital" (48). Attributing the effectiveness of the campaign to end open admissions in New York City to the rising influence of the wealthy and the disarray of traditional progressive advocates of social justice issues, Romer argues that the current period will lead either to stepped-up grassroots organizing or a tragic defeat of the interests of all but affluent New Yorkers. Unlike the ' $60 \mathrm{~s}$ mass protests for an open-door policy at CUNY, resistance to the campaign to close the door has been weak. As Romer puts it: "Academics, in the main, are not prepared to risk their jobs and students don't want to risk the opportunity for a share of American prosperity" (50). Especially disturbing is Romer's observation that a key component of the conservative campaign has been to demonize students in remedial programs, a tactic that "humiliated the students of CUNY into stunned inaction" (49).

Another instructive tale of the vulnerability of programs that have historically served under-represented students is Carol Severino's ex- 
amination of the "'urban mission' trope" at the University of Illinois at Chicago (UIC). Severino traces the birth in 1968 of UIC's Educational Assistance Program - a multiracial, academic support program - to popular resistance to the construction of the campus three years earlier and the displacement of established community organizations, including Jane Addams' Hull House, and a total of 10,000 residents. Although no one at UIC can account for the initial use of the term "urban mission," according to Severino, it was incorporated, albeit ambivalently, into UIC's undergraduate curriculum through EAP, which had been started in response to demands by Black community organizations for increased representation in the university.

Like its prototype, the SEEK program at City University, EAP stirred controversy among faculty concerned with the impact underprepared students would have on institutional standards. Poor retention rates, the development of separate, ethnically-defined programs, downsizing throughout the '70s and ' 80 s, and higher admissions standards all combined to weaken EAP severely. In 1993, Severino reports, EAP was converted into a recruitment and support program for African American students, eliminating academic instruction and totally abandoning its multiracial tradition. Most interesting in terms of how such programs have eroded and disappeared is Severino's rhetorical analysis of the fate of the "urban mission" trope itself. UIC's new mission statement for the 21st century explicitly rejects its "urban mission," replacing the phrase with "urban university in a land-grant tradition." As Severino comments, "The 'urban mission' is deemed 'narrow' and dismissed; UIC is now more oriented to the world than to its neighborhood" (50).

Meanwhile, paralleling assaults on open enrollment and academic support programs, affirmative action has been reversed in Texas, California, Washington, and most recently, Florida; legal challenges to affirmative action are pending in Michigan, Georgia, New York, Alabama, and North Carolina. Despite officials' repeated assurances of a continued commitment to diversity, the enrollment of historically under-represented students has decreased. As a University of Central Florida student noted in reaction to Governor Jeb Bush's plan to eliminate race and gender admissions criteria in Florida while guaranteeing the admission of the top twenty percent of graduating high school seniors to state universities: "This plan looks very good on paper. But if you really think about it, the top twenty percent of students go to college anyway" ("Regents" A18). The conservative doublespeak used to promote cultural diversity while wiping out equal opportunity programs reinscribes social inequalities in the name of fairness. Not surprisingly, diversity in selective universities - and those like CUNY with new policies designed to garner prestige -is diminishing. Both antiaffirmative action and anti-open enrollment policies have had the ef- 
fect of disqualifying poorly-prepared minorities and discouraging those who are better prepared from even applying. ${ }^{6}$

Along with the impact of socioeconomic disadvantages and the debilitating effects of racism on college admission statistics, a disproportionate number of minority students score low on standardized tests like the SATs. Consequently, diversity in higher education cannot be achieved without admissions criteria based on more accurate predictors of success in college, such as grade point averages, portfolio submissions, and extra-curricular activities. Even with more equitable admissions policies, the "savage inequalities" in public education in this country will continue in the foreseeable future to necessitate academic support services for many students - especially those who deal with multiple disadvantages in preschool and K-12-to get over the hump of the freshman year. In urban, working-class universities with a majority of students of color, such support gives often large numbers of poorly prepared students a chance to succeed academically (at LIU, over half of entering students place into basic writing and may take for credit as many as twelve hours of writing instruction altogether); at more selective institutions, the absence of support services, in combination with anti-affirmative policies that drive away both top- and bottom-rung students of color, literally means these students' disappearance. ${ }^{7}$

In a detailed analysis of these trends at the University of Washington, Gail Stygall describes what she calls the "double-bind" of antiundergraduate education and anti-affirmative action. Focusing on the rhetoric surrounding the passage and implementation of I-200, Stygall demystifies the final report of a gubernatorial commission on the future of higher education in Washington state. She shows that the commission's avowed commitment "to broadening the educational franchise" is literally cancelled out by the means - corporatization and privatization - by which it envisions meeting its goal. As Stygall ruefully puts it, "So we will actively recruit the under-represented students into something less than the regular universities. For 'them' we'll contract outside the university" (54).

A less veiled statement of aims can be seen in "An Institution Adrift," a report issued in 1999 by Mayor Giuliani's Task Force on CUNY. In the section titled "Rethinking Remediation's Place at CUNY," remediation is characterized as "a distraction from the main business of the University" (38). Rather than serve the people of New York City as CUNY has historically done, the Task Force, chaired by Benno Schmidt, maintains that the university's "mandate" is "to offer first-rate college-level programs to those who are prepared to succeed" (39). To "reconceptualize" and "reform" remediation-a goal that by the report's own admission will eliminate three-quarters of all entering degree students who fail one or more placement tests - the Task 
Force recommends the implementation of a "managed competition model" in which students could "purchase educational services from the provider of their choice... including for-profit companies" such as Kaplan and Sylvan Learning. It does not take much to read between the lines of this report to see the goals of privatization, corporatization, outsourcing, and downsizing in its recommendations.

\section{Making Sense of the Debates on Basic Writing}

This accelerating political assault on equal opportunity in higher education nationwide helps put our own debates on basic writing in perspective. Let me try to sketch the highlights of these debates, starting not with the earliest ones which date back to immediate reactions to Shaughnessy by critics like John Rouse, but with David Bartholomae's keynote speech in 1992 at the Fourth National Basic Writing Conference. Urging us to read against the grain of basic writing as "a grand narrative of liberal sympathy and liberal reform" and question its place in the curriculum, Bartholomae imagined a mainstream course in which students of different abilities and backgrounds would profit from confrontations in a cultural "contact zone." His characterization of basic writing as having lost its political edge, "reproducing the hierarchies we had meant to question and overthrow," is especially significant considering his own extensive role in transforming basic writing pedagogy from skills drills into a rigorous, intellectually-grounded course that in many places has become a standard approach at all levels of composition. ${ }^{8}$

Objecting to this revisionist view of basic writing, Karen Greenberg, who formerly directed the developmental English program at Hunter College, warned that unless composition experts assumed responsibility for developing more effective assessment procedures, administrators would do their job for them and programs would be destroyed. Five years later, in response to Ira Shor's call to abolish basic writing at the same conference in 1997, Greenberg again warned of a scenario at CUNY, which has now largely come true, of a university "far trimmed down in size ... return[ing] to the elite institution it was before 1970, when open admissions began" (94). Remaining one of basic writing's staunchest advocates, Greenberg straightforwardly defends the importance of basic writing instruction in the absence of vastly improved academic skills of entering students: "The instruction provided by basic writing courses enables students to acquire the academic literacy skills, motivation, and self-confidence to persevere and to succeed in college" (94).

Shor's provocative description of basic writing as "our apartheid" goes considerably beyond Bartholomae's proposed "contact zone" 
pedagogy to condemn college composition in general as a "correct usage gate" that promotes a "language policy" of "containment, control, and capital growth" (92). Rather than a sympathetic response to Black and Latino student demands by well-meaning, if sometimes naively liberal, educators, Shor views the inception of basic writing in the 1960s as "an extra layer of control ... needed to discipline students in an undisciplined age" (92). Today, he argues, a labor surplus in the American economy caused by globalization and downsizing has created a demand for low-wage service workers rather than college graduates; and basic writing functions to impede graduation rates and channel students into "burger-flipping jobs" (91). Very relevantly, he calls attention to an increasingly obscene disparity of wealth in the U.S. ${ }^{9}$ and, mirrored in our own profession, the exploitation of part-time adjuncts, graduate assistants, and other "flexible" workers who teach basic writing on the academic margins.

Shor's critique of education as a site for the reproduction of social inequities sheds light on how the apparatus of testing, tracking, vocational training, and college preparation functions to maintain the status quo. However, to indict basic writing and composition for deterring "a mass of aspiring students ... from democracy and from the American Dream" (95-6) obfuscates the real impediments to democratizing education, some of which I have enumerated above. Looked at in a somewhat different light, Shor's reprise of reproduction theory nevertheless raises useful questions: How have racial and class segregation functioned across institutions? To what extent will the resegregation of systems like CUNY create an "apartheid" in which the majority of students of color attend community college while their white counterparts repopulate the senior colleges? And what are the implications of the abysmal failure to desegregate public schools for the future of higher education?

Especially because of the correlation at many institutions between designated basic writers and racial and class minorities, another important set of questions revolves around the politics of representation. ${ }^{10}$ Understanding the tendency to view basic writers as "alien" and "other" in the context of academic discourse and community is crucial if we are to overcome the sort of social and linguistic prejudices that often determine our response both to students and their writing. MinZhan Lu's critical analysis of our underlying assumptions about language and learning illuminates, for example, how the view of "'academic discourse' as discrete, fixed, and unified" (166) persists in practice even though most teachers reject it in theory; and how our acceptance as teachers of writing of novice/expert and outsider/insider dichotomies perpetuates traditional hierarchies between literature and composition. She urges us to treat error as a matter of style and a process of negotiation, a perspective that repudiates cognitivist and 
cultural theories of writing development, both of which support a notion of basic writers as deficient, in favor of a social theory of writing that insists on the interrelationship of form and meaning and views writing as always sociopolitically situated. This critique of basic writing's essentializing tendencies goes to the heart of prejudices against nonstandard dialects, particularly Black English, and the reification of both standard English and academic discourse as higher forms of communication rather than as socially-constructed varieties of language.

As important as critical theory has been to rethinking leftist as well as mainstream assumptions and values, we should not let it obscure material, sociohistorical realities. If, for example, the critique of essentialist views of language and skills development leads teachers to believe that error is not a major issue for basic writers, as has certainly often been the case on my campus, then it does a disservice both to new teachers and to students. Adjunct teachers and graduate students at LIU routinely express confusion about the writing program's philosophy, despite repeated clarifications that our emphasis on reading, purposeful writing, and critical analysis should not supersede attention to form, including error.

More recently, I have been working with a middle school teacher who feels she has to sneak skills development into the classroom behind the backs of supervisors who advocate an "integrated" curriculum but are closely watching the results of a statewide eighth grade writing proficiency exam to monitor teachers' success rates on the basis of how well their students perform on the test. She believes that students in school districts like hers, described to me by the superintendent as "high poverty, racially isolated, and low-achieving" (Leverett), have been intentionally deprived of the skills taught to middle class white children. As Michael Newman observes, basic writing continues to be an important category, not because one dialect is superior to another, but because written errors send a message of exclusion. Thus, he argues, "The category remains because the words and forms used by basic writers will continue to tell the story of their aberration from academic discourse and academic life, and so frequently from their own dreams" (36).

In sum, if we are committed to democratizing education, as I believe most basic writing teachers and scholars are, we need to fight back against conservative efforts to reverse affirmative action, end open admissions, eliminate academic support programs, and thus resegregate higher education. To respond effectively at both local and national levels, we will need to understand the forces that compelled colleges and universities to open their doors to minority students in the first place as well as those that now threaten to shut them out. Basic 
writing can be seen as a strategic means of keeping the doors open for students like the writer of the placement test on the death penalty cited in my epigraph. ${ }^{11}$ To position ourselves and our students strategically means not to discount critiques of basic writing or to reject other models of instruction but rather to place such critiques in political and historical perspective and choose our battles carefully. Among them should be to heed Harvey Weiner's call to document the success of basic writing programs; to replicate the illuminating longitudinal study that Marilyn Sternglass conducted at City College; to experiment with new models of instruction or support existing successful programs, including WAC, depending on local conditions; ${ }^{12}$ to forge partnerships between universities and public schools; to continue to research literacy outside the classroom in a variety of sociohistorical contexts; to participate more actively and effectively in public debates on higher education; and to support the activist agenda of emerging movements led by groups like The Coalition to Defend Affirmative Action By Any Means Necessary (BAMN), a student organization at the University of California at Berkeley and the University of Michigan mobilizing opposition nationwide to anti-affirmative action legislation and the resegregation of universities.

\section{Notes}

1. We revised the LIU placement test in 1998 with the assistance of Brian Huot who helped us articulate the criteria for each level in the context of the particular needs of our program: a "low basic writer" could neither explain someone else's position nor develop an argument; a "high basic writer" could explain someone else's position but not develop an argument; and a writer who placed in freshman composition could do both tasks and was ready to build on those skills. For an excellent overview on assessment, see Kathleen Blake Yancey's "Looking Back as We Look Forward: Historicizing Writing Assessment." Also see Huot's and Yancey's coedited journal Assessing Writing.

2. At LIU, students who fail the placement test are required to take a noncredit course prior to the basic writing sequence; however, because such students rarely opt to attend the university, the course, though listed in the catalogue, rarely runs.

3. For an insightful analysis of placement tests written by basic writers, many of which reveal similar problems to those of the writer of my second example, see Mina Shaughnessy's chapter, "Beyond the Sentence," in Errors and Expectations. Explaining that students who 
lack vocabulary to deal with abstractions are often unable to move beyond literal comprehension of a question, Shaughnessy cites a passage from a student placement test: "I disagree on the fack the paragraph sed that when get old you must get it secondhand. Whell that is not true becatuse they are a god meney of older people hou can see a hear beter than the year one and this is true all over" (242).

4. I make this point partly in response to Bruce Horner's argument that the notion of basic writing as a new phenomenon cuts it off from its historical roots in remedial instruction and perpetuates its marginal status in the academy. While he is right on both counts in some respects, his argument is misleading, as I argue here, because basic writing did emerge at a particular historical conjuncture: the expansion in the 1960s of higher education to working-class students of color. It is in this historical context that basic writing can and should be seen as a new phenomenon.

5. The figures on the impact on minority students of eliminating remedial courses vary considerably, with even worse predictions made by CUNY sociologist David Lavin that 38 percent of whites, 70 percent of Latinos, 71 percent of Asians, and 67 percent of African Americans would be barred from the senior colleges (Staples).

6. According to the San Francisco Chronicle, even though more minority applicants were accepted to the University of California this year, there continues to be a marked decline in the number enrolled, a fact attributed to students' perception that they are unwelcome.

7. For a related view of the relationship of writing instruction to open admissions, see Cynthia Lewiecki-Wilson and Jeff Sommers' "Professing at the Fault Lines: Composition at Open Admissions Institutions." Lewiecki-Wilson and Sommers suggest that undergraduate writing instruction, particularly at open admissions institutions, can be seen as central rather than marginal to the academy, and question whether the demise of open admissions education will jeopardize the very survival of composition. They point out that conditions imposed on faculty like state-mandated testing and cutbacks resulting in a loss of courses and staff "exert pressure to move backward ...to pre-process models" instead of forward to "post-process critiques" (458).

8. See Peter Dow Adams's "Basic Writing Reconsidered" for a critique of the message sent to basic writers by homogeneous classes and his view on the impact of composition research findings on all levels of classroom instruction 
9. According to Forbes magazine's list of the 400 richest Americans, the number of billionaires in the U.S. has leapt from thirteen in 1982 to 268 in 1999; along with this concentration of wealth at the top - the top one percent of American households have more than the bottom 95 percent combined -35 million people live below the official poverty line of $\$ 13,000$ for a three-person family (Sklar 23 ).

10. Laura Gray-Rosendale points out that the preoccupation with categorizing basic writers presupposes their identity before they arrive in the classroom. She traces the ways the question of identity has been dealt with from Helmers' account of the most pernicious representations of basic writers as "grotesque and deviant" (7) to frustration with the question itself as overly inclusive, homogenizing and simplifying the characteristics of a diverse population. What I find telling-even comical if it were not so serious an issue - is the return again and again, despite increasing objections, to the linkage of basic writers with class and ethnic markers from Bartholomae and Petrosky's depiction of them as "outside the mainstream" and mostly "minority or special-admission students" (8) to Sheridan-Rabideau and Brossel's contention that basic writers are "at-risk students" constituted by "new and diverse populations" (10). Our collective discomfort with this racialized, classconscious description of basic writers should, I believe, serve as a mirror for us to examine our own attitudes and assumptions, to redouble our efforts not to stereotype any student on the basis of race, class, gender, or other identifications while at the same time ensuring that our newfound awareness of the pervasiveness of racism in our society does not lead us to ignore it.

11. To advocate for this student would stir controversy among my colleagues, many of whom would strongly disagree with me.

12. See, e.g., Mary Soliday's account of mainstreaming at City College and Rhonda Grego and Nancy Thompson's report on the replacement of basic writing with a Writing Studio at the University of South Carolina.

\section{Works Cited}

Adams, Peter Dow. "Basic Writing Reconsidered." Journal of Basic Writing 12.1 (1993): 22-36.

Arenson, Karen W. "Report Says Entry Tests Would Sharply Cut CUNY Enrollment." New York Times 5 May 1998: B6.

Bartholomae, David. "The Tidy House: Basic Writing in the American Curriculum." JBW12.1 (1993): 4-21.

The Coalition to Defend Affirmative Action By Any Means Necessary 
(BAMN). 14 Feb. 2000. <http://www.bamn.com/>.

Greenberg, Karen. "The Politics of Basic Writing." JBW12.1 (1993): 6471.

- -. "A Response to Ira Shor's 'Our Apartheid: Writing Instruction and Inequality."' JBW16.2 (1997): 90-94.

Grego, Rhonda, and Nancy Thompson. "Repositioning Remediation: Renegotiating Composition's Work in the Academy." CCC 47 (Feb. 1996): 62-84.

Horner, Bruce. "Discoursing Basic Writing." CCC 47 (May 1996): 199. 222.

Leverett, Larry. Personal Interview. Sept. 23, 1999.

Lu, Min-Zhan. "Professing Multiculturalism: The Politics of Style in the Contact Zone." In Representing the "Other": Basic Writers and the Teaching of Basic Writing. Min-Zhan Lu and Bruce Horner. Urbana, IL: NCTE, 1999.

Newman, Michael. "Correctness and Its Conceptions: The Meaning of Language Form for Basic Writers." JBW15.1 (1996): 23-38.

Piven, Frances Fox, and Richard A. Cloward. The Breaking of the American Compact. New York: The New Press, 1997.

Rich, Adrienne. "Teaching Language in Open Admissions." On Lies, Secrets, and Silence: Selected Prose 1966-1978. New York: W.W. Norton, 1979.

Romer, Nancy. "The CUNY Struggle: Class \& Race in Public Higher Education." New Politics (Winter 1999): 47-56.

Rouse, John. "The Politics of Composition." College English 41 (Sept. 1979): 1-12.

Schmidt, Benno C. The City University of New York: An Institution Adrift. Report of the Mayor's Advisory Task Force on The City University of New York. June 7, 1999.

Severino, Carol. "An Urban University and Its Academic Support Program: Teaching Basic Writing in the Context of an 'Urban Mission.'" JBW15.1 (1996): 39-56.

Shaughnessy, Mina. Errors and Expectations: A Guide for the Teacher of Basic Writing. New York: Oxford UP, 1977.

Shor, Ira. "Our Apartheid: Writing Instruction and Inequality." JBW 16.1 (1997): 91-104.

Sklar, Holly. "Brother, Can You Spare a Million." $Z$ Magazine Dec. 1999: 23-26.

Soliday, Mary. "From the Margins to the Mainstream; Reconceiving Remediation." College Composition and Communication 47 (Feb. 1996): 85-100.

Staples, Brent. "Blocking Promising Students from City University." Editorial. New York Times 26 May 1998: A20.

Sternglass, Marilyn. Time to Know Them: A Longitudinal Study of Writing and Learning at the College Level. Mahwah, N.J.: Lawrence 
Erlbaum Associates, Publishers, 1997.

Stygall, Gail. "Unraveling at Both Ends: Anti-Undergraduate Education, Anti-Affirmative Action, and Basic Writing at Research Schools." JBW18.2 (1999): 40-58.

Weiner, Harvey. "The Attack on Basic Writing - and After." JBW17.1 (1998): 96-103.

Weisen Cook, Blanche, and Sandi E. Cooper. "The Trashing of CUNY." Editorial. New York Times 8 Sept. 1994: A25.

Yancey, Kathleen Blake. "Looking Back as We Look Forward: Historicizing Writing Assessment." CCC50 (Feb. 1999): 483-503. 


\title{
Judith Rodby and Tom Fox
}

\section{BASIC WORK AND MATERIAL ACTS: THE IRONIES, \\ DISCREPANCIES, AND \\ DISJUNCTURES OF BASIC WRITING AND \\ MAINSTREAMING}

\begin{abstract}
Basic Work and Material Acts" summarizes what we have learned from mainstreaming basic writers in first-year composition at California State University, Chico. We found that "basic writing" as an institutional structure (defined by the State of California as remedial and granted no baccalaureate credit) created basic writers. Once basic writers were in the context of first-year composition, "basic writing" as a concept and as a practice disappeared. Two related principles about learning to write emerge from this experience: 1) one learns to do college writing by being in the context of college writing, not in some other context; and 2) literacy learning does not come in discrete levels. Drawing upon these insights, we go on to describe the ways that our program supports writers in first-year composition through adjunct workshops. The material circumstances of our program support students' college writing in ways that lessen the punitive nature of basic writing and are coherent with recent research in literacy studies.
\end{abstract}

Seven years ago, we eliminated basic writing courses because of our commitment to broadening student access to the university and its ways of using language and literacy. This is ironic, of course, because twenty years prior most basic writing courses had been instituted to do precisely the same thing - broaden student access to university education. It is also ironic because conservative voices, especially in California and New York, have been arguing for the elimination of remediation on four-year campuses. Their argument has to do with

Judith Rodby is Professor of English at California State University, Chico and Coordinator of First Year Adjunct Writing Workshops. She is the author of Appropriating Literacy and articles about ESL literacy and composition. She also researches youth media and communities of practice.

Tom Fox is Professor of English at California State University, Chico and Director of the Northern California Writing Project. He regularly teaches first-year writing, as well as graduate and undergraduate courses in composition. He is author of Social Uses of Writing, co-editor of Writing With: New Directions in Collaborative Teaching, Learning, and Research and, Defending Access and articles about the politics of composition. 


\section{limiting access.}

Our decision to eliminate basic writing grew from our experiences with our students, by a realization that "basic" did not describe the students' practices, but operated as a construct that supported a remedial economic structure that distributed "credit" unequally. Our understandings were supported by the series of critiques of basic writing, especially those coming from the Fourth National Basic Writing conference, that questioned both the definitions of "basic writer" and the effectiveness of the programs (Bartholomae; Jones; Adams; Fox). By focusing on the material conditions - the actual, practical pedagogy of who is in what room, what credit students receive, what kinds of questions and critiques occur in what context-we hope to answer concerns that these critiques somehow ignore the realities of basic writing students' experiences. Bruce Horner sums up these worries:

To teachers concerned with their own and their students' immediate institutional survival, however, any suggestion that "basic writing" is a construct may seem an elitist gesture from those situated to afford engagement in fine theoretical distinctions, at best an irresponsible admission, but in any event likely to provide fodder for those on the New Right attacking basic writing programs, teachers, and students. (191-192)

Our program changes, while supported by the "fine theory," were more powerfully shaped by careful attention to what students were saying and doing. The program reforms argued for in this article emerged from the ground up and made necessary a corresponding change in our theory. By doing so, we hope to initiate a dialogue with those teachers and writing program administrators who have seen the critique of basic writing primarily the concern of postmodern composition theorists. We also wish-as strongly as possible-to demonstrate that our theories and practices move in the opposite direction from those on the New Right and therefore could not easily be appropriated by them. By focusing on the dialectic between material conditions and theory, we also hope to show how careful attention to students and their concerns can produce powerful and sophisticated changes in instruction.

\section{History of Basic Writing at CSU, Chico}

In the late 1980s and early 1990s, student and teacher complaints showed that our basic writing courses had been backfiring. Instead of increasing student access, they had discouraged students by requiring them to work a year in writing courses where they accrued no credits. 
The university economy of giving credit for work had commodified the activities of writing and reading in both the basic writing course and the "real" first-year writing course. Practices of writing and reading were defined by their purchase power - what they were worth in credit value was what they were. Students complained about the worthlessness of their work in basic writing; faculty complained about their failures in motivating students to invest in what students saw as "worthless" writing (see Rodby for a fuller discussion of the issue of credit).

The curriculum was fairly standard fare for the time. Many basic writing faculty worked from the notion that certain modes or types of essays such as the personal narrative or description were simpler than the exposition and argument that were done in first-year writing. Faculty felt students needed to do these simpler tasks first because they would prepare them for the harder activities in first-year writing. Further, faculty argued that in a beginning writing course students need to feel comfortable and achieve fluency. They need to write easily. This comfort and ease would be produced by asking students to write about what they knew. However, all too often students just thought the course was easy, too easy, in fact. And the course backfired.

In this environment, all too often students did not use writing and reading for gaining or making knowledge, for communicating with their instructor or fellow students, or even for expressing their multiple senses of self. Writing and reading were neither acts nor actions. Resisting any investment in basic writing courses, the students wrote very basic texts with minimal goals, purposes, topics and language. For some students basic writing courses were toxic. They said they were "sick of writing" and that writing and reading had become a punishment.

Basic writing classes had produced basic writing. And so it was not a surprise that we received frequent feedback from faculty in firstyear writing that the basic writing students were not adequately "prepared" for work in their classes, even though this was also the case for many of the students enrolled in first-year writing. Frustrated with the context of basic writing (no credit and disinterested students), faculty tried to rehabilitate the scene of basic writing courses. In hopes that students would see the connection between basic writing and the demands of future writing courses, the faculty's curriculum began to resemble the first-year writing course.

In so doing, the basic writing curriculum, as it had been previously defined, began to disappear. In some cases, faculty argued that basic writing students needed to be challenged and that they would work harder and appreciate the course more if the course content were more demanding. We all thought that if we could demonstrate the rigors of the basic writing courses, we could more successfully argue 
that the students' labor deserved credit. But while the basic writing courses changed, the economy legitimizing them did not. Therefore, the courses remained without credit. After all, basic writing was by definition a course without credit, no matter what was accomplished by the students.

The student opposition was not quelled or even tempered by the curricular changes. Cynicism grew as the tautology underlying basic writing became more and more apparent. To mitigate the growing discontent, we allowed students to petition to skip one or more basic writing courses, based on interviews, evidence of motivation, teacher recommendation or writing samples. And through this process we learned that many students with low test scores could succeed in first-year writing. They didn't need to learn something basic first. If basic writing was produced and reproduced by the context of basic writing courses, perhaps basic writing would disappear if students were asked to write and read in the context of a regular first-year writing course. After a year of permitting students to skip basic writing, we abolished the courses themselves. No one (but the students who no longer had to take them) really noticed that these classes were gone. By this point the courses had largely disappeared anyway. That is, already revised was the curriculum, which presumed students needed to learn "basic writing skills" before they could do first-year writing.

The relationship between "ability" and "context" has been written about in compelling ways elsewhere. For instance, Ralph Cintron, in Angel's Town, writes about a fourteen year old boy named Valerio who had been diagnosed as learning disabled. Similar to our sense that "basic writing" might disappear without the context of the basic writing program, Cintron writes about Valerio's skills:

His nonverbal skills were at least average and he scored well on yes/no tests and, interestingly enough, on activities that required connected discourse. It was as if in the everyday world where discourse is largely performative and social, constructed in groups or dialogically, he did well.. . . it was almost as if Valerio's learning disabilities might vanish within a context that was not a testing ground. (101-102)

Additionally, studies of the writing process have argued that context powerfully affects what writers do. In 1985 , James A. Reither argued that "writing and what writers do during writing cannot be artificially separated from the social-rhetorical situations in which writing gets done, from the conditions that enable writers to do what they do and from the motive writers have for doing what they do (621). And in 1986 Marilyn Cooper followed with her seminal article, "Ecology of Writing" that states, "all of the characteristics of any individual writer 
or piece of writing both determine and are determined by the characteristics of all the other writers and writings in the systems" (7).

Since we abandoned the structure and the construct of basic writing, we have enrolled all students needing to fulfill the first-year writing requirement in first-year writing. Those who enter with low scores on the English Placement Test are also enrolled in an adjunct writing workshop. We serve nearly one thousand students each year in the adjunct workshops. For these adjunct workshops, students receive one credit that can be applied to financial aid or athletic eligibility but not to graduation credits. To pass first-year writing, students must receive credit in the workshop, which they earn through attendance and participation. If they complete the quantity requirements for firstyear writing and the workshop but their writing does not demonstrate the goals of the course, they may receive a no-credit "placeholder" grade in first-year writing and will repeat the course until they have passed it. Approximately $14 \%$ take the course more than once and less than $1 \%$ fail it again.

This is not the ideal arrangement. Low-scoring students are still required to attend a class for which they do not receive graduation credits, and they are still separated out from the other students taking first-year writing. Repeatedly faculty remark that they wish the workshops were available for all of their students, or alternately, that they could recommend students for the workshop based on demonstrated need after a couple of weeks of classes. But the State University's Chancellor's office mandates that we separate out the students with low test scores. So, for the time being, in this set of circumstances, this is the best compromise we can make.

\section{Emerging Principles about Writing Instruction}

Out of our pedagogical labors - our evolving curriculum and interactions with students and our structure of workshops-emerged several theoretical insights which have slowly developed into principles we have used to structure the first-year writing program:

a) One learns to participate in a particular writing practice by being engaged in that practice and not by learning some other writing practice with the idea that the latter prepares writers for the former. This insight grew out of our repeated observations that $x$ did not lead to $y$. Students who took basic writing did not seem particularly prepared or unprepared for first-year writing. The basic writing students who had achieved a degree of comfort and expertise in the curriculum of basic writing (through short readings, usually multicultural, often narrative, and short papers based on the students' own life experience) did not bring that comfort and expertise with them to first-year writ- 
ing. Even at the most banal level, the ability to punctuate a sentence, for example, expertise from Basic Writing courses did not appear to transfer automatically to first-year writing.

Literally, some students seemed to have learned to revise in basic writing courses and be stymied in first-year writing revision. How to explain this disjuncture? What we learned was that the term revision (as an example) refers to an array of practices. When students revised personal narrative essays, for example, they might have been admonished to provide extensive sensory detail and to work on "showing" not "telling." However, when these students revise their expository pieces, they were advised to explain more (and "tell" rather than "show"). In other words, to call an activity revision does not mean that a student will understand what revision is or means in all situations with all texts.

Our insights about the variety of practices entailed in the word writing (or revision, research, sources, topic, etc.) were supported by research from ethnographic studies that suggested that writing can not be conceived of as a static bunch of skills to be moved from place to place (like things in a suitcase, as Elspeth Stuckey has written). Writing is a practice, defined by Scribner and Cole as "a set of socially organized activities using a particular technology and particular systems of knowledge" (236). In fact, different writing practices may or may not share conceptual and or procedural knowledge bases. They may have little in common, in other words. Writing practices may be so dissimilar that it is only a tool (a pen, for example) that acts as a flag to alert us that what people are doing is writing. When writing is viewed as a practice, skills may not be defined as a set of discrete and constant things that one can know or know how to do but as:

a) "[C]oordinated sets of actions, which apply knowledge to particular settings" (Scribner and Cole 236). The specific nature of the activities or literacy practices determines the kinds of skills and knowledge associated with literacy. As Scribner and Cole point out, letter writing, diary keeping, making a family album, and keeping a ledger of crop sales involve many different types of knowledge and multiple sets of skills. Whether one knows how to read and write is not an absolute value; what one knows and does changes radically from situation to situation. The insight we gained is the extent to which Scribner and Cole's claim is true even to two closely related contexts: two university writing courses taken in sequence. The contextual change comes with the fact that students construct a no-credit course much differently than a credit-bearing one.

b) As a corollary to a), we began to understand writing not as an activity that is learned (or best taught) in levels. Our tacit assumptions about the validity of discrete levels of instructions gradually eroded. We questioned whether or not it was possible to ascertain what would 
make a writing practice more "simple" or "basic" than another or to design simple writing and reading practices that would actually be the grounding for other practices. Our conclusions are that such gradations of writing are at the very least unhelpful, and at the most misrepresent the act of writing. For instance, narrative is often placed at a level "lower" (or earlier) in the curriculum than analysis or argumentation. Such "levels" make it more pedagogically difficult to teach writing. Narrative becomes an unreflective "natural" genre, and analysis becomes an academic exercise divorced from student concerns. It makes a great deal more sense to imagine writing in actual scenes, a "narrative" emerges as the genre because the situation calls for a story. Levels of discourse, especially as they are inappropriately related to levels of ability, make little sense.

c) Writing and reading practices and second language acquisition should not be conflated. Many of the students placed into basic writing were non-native speakers of English. This placement was based on the judgment that their writing was in some sense basic when what had actually been judged was their language acquisition. Their understanding and ability to do certain types of writing - to practice writing and act through writing - was never in question. Perhaps these students could not engage in the practices of writing in first-year writing because they needed to acquire more English vocabulary and syntax, but they didn't need basic writing first. Alternately, some of these non-native speakers might have been able to approximate the acts of academic writing even though they would have had many errors in their English. The differences in these two understandings of non-native speakers' needs may seem so slight as to be inconsequential - but the differences in considering writing practices and language acquisition are actually quite significant. Putting non-native speakers in basic writing assumes that they need to work on their writing, and that working on simple writing tasks will prepare them for more complex writing tasks. However, these non-native speakers may be quite sophisticated in terms of writing and literacy practices. That is, they may be familiar and comfortable with a variety of writing practices while needing to work on their language correctness. Or they may need to work on both their writing practices and their language but one will not automatically or necessarily entail the other. The point is, in light of a) and b), the placement of non-native speakers in basic writing is doubly inappropriate. In our program students who needed to work on their language could take EFL classes and receive credits counted as foreign languages. 


\section{The Adjunct Workshops}

We will illustrate these principles in material circumstances and focus particularly on the adjunct workshops. As mentioned above, in our restructured program (after we abolished basic writing courses) all students needing to take first-year writing courses enroll in firstyear writing, regardless of test scores. We designed a structure, the adjunct workshops, to support (low-test scoring) students' learning while they were taking first-year writing.

The workshops meet twice a week for 50 minutes each time and are limited to 12 students per section, so each workshop has students from different sections of first-year writing. Because our program does not have a common syllabus, a single section of the adjunct workshop could, theoretically, have students with 12 different syllabi. Our emphasis in the first-year writing course is on so-called academic writing practices: research, entering into dialogue with sources, writing and revising papers that are idea-driven, making arguments, etc. In several sections the students are using Ways of Reading (Bartholomae and Petrosky) and in numerous others, the students are reading bell hooks, Ralph Cintron, and Cornel West and writing cultural critiques. The adjunct workshops do not have a curriculum that is independent of the work the students do in first-year writing. We have long abandoned the notion that we can teach writing in any generic sense. We do not think, for example, that we can productively teach "prewriting" and then ask students to do it on any and all writing assignments.

\section{An Adjunct Workshop Day}

To give readers a sense of how these workshops function, the following is a representation of a typical day in a workshop. Meeting in a small room on the ground floor of the English building, the students arrive one by one in the ten minutes before class has started. The instructor checks in with each student as she or he arrives. "What are you working on in first-year writing?" she asks. As the students answer, and the instructor makes notes on the board beside their names: Tim has a first draft due next week of a paper based on "The Arts of the Contact Zone" essay. He has not started writing. Jason is revising paper from his Ways of Reading assignment based on Patricia Limerick's essay " Empire of Innocence." He has brought copies for the class. Bu is also revising a paper and says it is going well. Marissa and Charles come in together. They are reading bell hooks. He groans and says she is a racist. Marissa concurs and makes a face. She says hooks's language is "nasty." Tina has met the instructor in the hall before class, asking if she could go over her paper draft due next week. Sean and 
Autumn are in different sections of the same first-year writing instructor's course. They just got a new writing assignment, which is also based on bell hooks. They both say they don't really understand either the assignment or the reading. Autumn confesses that she wasn't actually in class and that she had picked up the assignment from her friend. Charles wants to know if Autumn and Sean agree that hooks is a racist.

When everyone is present, the instructor and the students decide on the agenda for the day. Jason has brought copies of his paper so the class agrees to go over Jason's paper, in part, because that was the agenda planned at the end of the previous class period. The instructor first asks Tina about her paper and whether it can wait for the next class period and then queries the rest of the class about their work, referring to the board while doing so. Tina says she can wait until next class period to go over her draft because she sees that Sean, Autumn, Marissa and Charles all need help with "this hooks thing."

But first the class will work on Jason's paper. From a folder, the instructor pulls out a transparency copy of Jason's assignment and puts it on the overhead projector. The class knows the routine; they paraphrase what the assignment is asking of Jason. Marissa volunteers to write this summary on the board. Next, Jason voices his concerns; he is worried that his "second primary source doesn't seem to fit with the rest of the paper." Before moving to the draft itself, the instructor asks Jason what his other primary sources are and how he is using them. Then the instructor directs the class to focus on how Jason is using this source he is worried about. They should think about how he could use this source. The students read the paper silently, making notes on the pages and at the end. Jason's concerns about sources are discussed at length. After a debate that the instructor moderates, the class concurs that Jason is trying to use an interview about a text as though it were the text itself and that is the problem. Several students volunteer solutions which Marissa writes on the board.

The class is impatient for the bell hooks discussion: Charles almost shouts out - can we talk about hooks now? The students reading hooks explain what they have read and why they think she is a racist. Marissa is quite expressive: "This is not what I would expect from college. Why are we reading this stuff in college? I want to leave it [some of hooks' expressions] on the streets. I am going to college to get away from this." Sean and Autumn are generally quiet, and Autumn reminds the group that they have an assignment on hooks that they don't understand. The atmosphere is boisterous - a bit rowdy even. Jason and Bu have a side conversation about hooks - Bu is confused about who she is. The instructor says "ok - let's take a look at one of the passages and try to figure out what she is saying and doing and why. We can also think about what your instructor's motives are 
for assigning this reading and compare these goals to hooks's motives. Are they the same or different? Then we will move to the assignment." The class continues to be a bit rowdy as students find their books, move chairs and share copies of hooks' essay. Marissa says, "lets look at page 10 - now that's a really stupid part." And so the discussion continues.

The workshop described above is hardly unusual for composition classes. The adjunct workshop spends much of its time in large group discussion, but some workshop leaders divide the ten students into smaller groups or pairs. The students may even work individually with the instructor some of the time. One instructor, Ivory Veale, reported that he had asked students to take out a paper that had been commented on by their first-year writing teachers and to formulate two questions about their teachers' comments. Veale reports in his teaching log that he then went around the room "helped each student find ways to resolve issues in their drafts that their teachers had problems with."

These small group workshops have been successful. The students enrolled in the workshop generally pass the first-year writing course the first time (86\%). And $10 \%$ of the $14 \%$ who have to repeat have had problems coming to class and doing the work rather than problems with being able to do the work well enough. One group of students who repeat first-year writing also tends to fail several other courses at the same time. These students usually have many obstacles to overcome in attending class and completing assignments, but usually not writing ability. They may lack transportation, money, or even a place to live. They may have small children, jobs, or older relatives to support. Another group of students who have to repeat consists of students who report that they did not think the course would be difficult. Their expectations of what the course was about were not accurate and they realized the mismatch too late. This second group usually does well in first-year writing when they repeat (with a B- average). When repeating the course, the first group may need additional support to finish the assignments on time - planning out strategies of time management, breaking down the task into component parts, etc. We provide this additional assistance in the workshop or occasionally through individual tutoring with an adjunct workshop instructor.

\section{Situated Learning}

Why does the small group workshop instruction work? Recent work in cognitive science provides a framework for describing how writers learn a new writing practice, as they usually do in first-year writing. They begin with limited information. The writing class may 
not provide them with sufficient information about the practice they are to learn - perhaps because the teacher thinks that all types of writing demand the same basic "skills" and that these skills transfer from one context to another. Perhaps the writing teacher believes that students should already know all of these basics. But even if the teacher's intent is to explain the particular practice being taught, the writing class may not offer students models of writing practices that would enable them to know what is being expected of them. "The writing process" does not capture the ways in which real life, everyday writing practices are stretched over time and space and involve activities, tools and interactions that may not even appear to be about literacy at all. Students often cannot learn enough about literacy practices through direct observation (if there even is anything to observe).

Students need to construct a mental model of what writing is in this new context. Most likely they begin by borrowing a model from another writing practice (context), calling up a scheme that seems to match the new situation in some way or ways. Whether this abduction and modification of old mental models is successful or not is in large part determined by the social relationships and the interactive context that constitutes the literacy practice itself. Urs Fuhrer, in "Behavior Setting Analysis of Situated Learning: The Case of the Newcomer" states that the "need for understanding is aroused by perception of an incongruous event, [understanding] is developed and supported by dialogue and peer group approval and it flourishes if mental modeling is unhindered by the immediate need for a definitive solution to the problem" (11).

In an ideal workshop situation, students are able to discuss possibilities for carrying out the writing practices they are being asked to engage in: What are the goals? Why do this? What do you need to know to do this? What tools - books, computer resources, journal articles, etc. - are necessary? How can it be carried out? Some workshop leaders ask students explicitly to describe the actual practice that students will engage in, to project a mental model of that practice, and plan the time and space they will work in. In response to these questions, one student writes the following plan:

I should probably set aside at least one hour per day in the morning to work on first-year writing in the computer lab it is not crowded then and I can get a station and print my drafts easily. I need to print out drafts to see what mistakes I am making. I need to ask my roommate to read my drafts too.

Another student pinpoints how her living situation has affected her practices: 
I should start my homework earlier in the day because when night rolls around, I like to visit with my friends. I have to somehow learn to do this in little bits and not all at once because I do not have long periods of quiet in my room. I hate going to the library and the computers labs on campus. One more thing - somehow I need to learn not to be so simple in my writing. Maybe talking about this paper in workshop will help. I never thought being complicated was good but I keep getting some comments about that on my papers.

In the adjunct workshops interaction and dialogue among students and students and instructor is crucial to learning new writing practices. Dialogue offers students many different perspectives on the practice and may elucidate the material details of seemingly mysterious or abstract aspects of writing. The student above worried about how to write less simply and brought her concerns to the group where her process and topic were discussed at length. What did "complicated" mean? What did one actually do to make an idea complicated? In a teaching log, workshop leader Colleen Harvel reports that one of her students

responds very positively to two things - in both he sees that I am, effectively, doing the work with him. He also seemed encouraged with the fact that I am struggling with the Foucault. First I showed Ricardo how to break up words and how to look up words in a dictionary. Ricardo was quite surprised when I showed him how to use a dictionary. He said something like "I didn't know you could get all of that out of a dictionary." But he was also somewhat discouraged and intimidated. He asked me if he had to do this for all of the words he didn't know. I told him that he could probably make an educated guess on lots of words.

The workshop leader also said that she and the student would explain Foucault to the others in the workshop. She paraphrased one passage and Ricardo the next.

The instructor's role in the workshop dialogue is not only to model processes and practices but to reframe questions or concerns. In the examples above, the student Jason was concerned about the form of his essay and where a secondary source would fit. The instructor reframed the question as one of motive and purpose so that Jason could begin to grasp a new understanding of the practice in which he was engaged. What is it for? The instructor points to the hooks reading and her motives and those of the teacher's before jumping into the specifics of the writing assignment that Autumn and Sean do not understand. 


\section{Productive Conflict}

Recent work on basic writing has identified students' experience of cultural conflicts as a central feature of writing instruction. MinZhan Lu's "Conflict and Struggle: Enemies or Preconditions of Basic Writing" and David Bartholomae's "The Tidy House" argue that the tendency to avoid or erase conflict is detrimental to writing students. $\mathrm{Lu}$ argues that conflict and struggle are "preconditions for all discursive acts" (33), and are especially important for students who do not fit comfortably within the academy. Bartholomae worries that basic writing programs can "hide contestations" through a liberal desire to separate out difference so that it doesn't come in contact with the mainstream. For these reasons and others, we welcome and try to make productive use of the kind of conflict that Marissa and Charles bring up about hooks.

We think that the workshop structure particularly encourages productive conflict. Many authors have written about the ways that collaborative groups tend to produce resistance to the class. Thia Wolf's study, "Conflict as Opportunity in Collaborative Praxis" is one of the best examples. Wolf cites example after example of students resisting the teachers' directions, texts, and even critiquing her behavior in collaborative groups. Wolf also notes that these critiques rarely make it back to the teacher, but instead are denied classroom agency. Her explanation for this is that although students often "wish to assert themselves against the demands of authority," they simultaneously "wish to protect themselves" and thus, "deny the possibility of agency in their actions" (95).

The workshop has an unusual status. It is not an adjunct to a particular class or particular teacher, and thus differs from most other adjunct tutoring models. It has an important autonomy from the firstyear writing class. The workshop instructor is not an extension of the teacher, nor does the workshop leader grade the students, other than for attendance and participation. Yet it is still a legitimate space in the academy (i.e. someone is paid to be the workshop instructor; it is held in a university classroom; the students are on a roll sheet, etc.).

This combination of legitimacy and separation provides the students with a space and time to take on different roles from the ones they play in the larger classroom. If, for example, they are quiet in the first-year writing class because they do not understand the purposes of the course or the ideas of a reading, they may be able to openly, even vociferously, resist the first-year writing class and its means in the workshop. The role of the workshop leader is to reframe the resistance so that the student can examine what hooks is up to, or why Foucault's language is so difficult. The workshop instructors report 
that they believe that because the workshop is not graded and students are not in the workshop with others with whom they are competing for grades, they are "free" to express confusion, despair, anger, and opinions that they could not raise in the first-year writing class because it is graded. It seems that with this workshop there is the possibility that writing may not be always already a commodity, that the workshop may complement the first-year writing course as students enter into conflict and dialogue and experience agency with respect to the curriculum.

The experience in the workshop changes the nature of the firstyear writing class itself. The students have a forum that is institutionally-sanctioned where they discuss the goings on in their first-year writing class with other writing instructors (their workshop leaders) and with other students from other sections. The instructors' teaching practices - down to the concrete details of their assignments, their responses, their reading choice, their grading, even their classroom demeanor-are all made public in a context where the instructor is not present.

Some instructors see this feature of the workshop as threatening, as uncomfortably undermining their authority. Sometimes tensions emerge between the workshop leaders and instructors over what's done in the workshops, or how commentaries on the first year composition class are handled. As program administrators, we don't think that this tension is necessarily a bad thing - as long as both parties behave with professional respect. Instead, the conflict between what goes on in the workshop and what goes on in the classroom is enormously helpful, provided instructors see resistance as constructively pressuring their teaching practices.

Especially in light of our primary concern for access, the discourse of the workshop offers insight into changes in our pedagogy. For instance, hooks's essay was chosen because she writes from the perspective of an African American woman, and for some students, this perspective may invite them to engage in the kind of critical writing we encourage in our program. Hooks was chosen, in other words, because we believed that she would invite students of color to make connections with her academic project. Marissa, however, also a student of color, found hooks's language to be a barrier, part of a cultural divide. The workshop leader, by asking the series of questions about hooks's language, treats Marissa's concerns as legitimate and worthy of rigorous inquiry. She models an academic critique, making it more possible that Marissa could raise the issue in her first-year writing class, and more possible that Marissa could develop such a critique into something that she could write for her first-year writing class.

In first-year writing classes, it is a common occurrence for students to begin a critique of a writing or reading assignment by stating, 
"I was talking about this in my workshop...." The forum of the workshop deprivatizes the classroom; the force of the teacher's authority in the closed-door room is changed by the workshop, making the students - especially the students who may feel reluctant to raise issues in the class as a whole - more likely to give critical feedback on the teacher's practice. The public nature of teaching in this program, its openness to critique from many sides, may make teaching a little more stressful, but it certainly also makes teachers more consistently self-critical.

The change in pedagogy - and especially the changes in the traditional arrangement of students in a single classroom - make visible and public the struggles and talents of both teachers and students. The workshop structure allows students to try on discursive practices of academic writing without fear of being graded, and thus make visible conflicts with texts, teachers, classrooms, assignments, and responses. This visibility allows the program and students to see a broader range of language use and provides us with more opportunities to teach. Teachers, too, are made more visible by this structure. Their failures to communicate, their misfired responses, their terrific assignments, their passion, and their unintended slights are all public, all open to comment and critique. This broad visibility, the display of a remarkable variety of responses to our first year writing class, has the ironic consequence of making basic writing disappear.

The specifics of the practices of this program, what workshop leaders say, what students struggle with, how teachers perceive and make use of the adjunct workshop, are the material practices that together are part of an effort to make our writing program less of a barrier for students who may not be immediately successful doing college writing. They add up to both an intellectual project and a political stance (they are not separate). Intellectually, we seek to understand the relationships between writing ability, context, teaching and learning relationships, and the acquisition of new skills. Politically, we do this work in order to insure that those very students who are often selected by the placement test because they do not easily slide into the academic world are not punished by their difference.

\section{Works Cited}

Adams, Peter Dow. "Basic Writing Reconsidered." Journal of BasicWriting 12:1 (1993), 22-26.

Bartholomae, David. "The Tidy House: Basic Writing in the American Curriculum." JBW12:1 (1993), 4-21.

Bartholomae, David and Anthony Petrosky. Ways of Reading $5^{\text {th }}$ Edition. Boston: St. Martin's, 1999.

Cintron, Ralph. Angel's Town: Chero Ways, Gang Life, and Rhetorics of the 
Everyday. Boston: Beacon, 1997.

Cooper, Marilyn. "The Ecology of Writing." In Writing as Social Action. Upper Montclair, NJ: Boynton/Cook, 1986.

Fox, Tom. "Standards and Access." JBW12:1(1993), 37-45.

Fuhrer, Urs. "Behavior Setting Analysis of Situated Learning: The Case of the Newcomer." In Chaiklin, Seth and Jean Lave, Eds. Understanding Practice: Perspectives on Activity and Context. Cambridge: Cambridge University Press, 1993.

Horner, Bruce and Min-Zhan Lu. Representing the "Other": Basic Writers and the Teaching of Basic Writing. Urbana, IL:NCTE, 1999.

Jones, William. "Basic Writing: Pushing Against Racism." JBW 12:1, (1993) 72-80.

Rodby, Judith. "What It's For and What It's Worth." College Composition and Communication 47:1 (1996), 105-111.

Reither, James. "Writing and Knowing: Towards Redefining the Writing Process." In The Writing Teacher's Sourcebook $4^{\text {th }}$ Edition. New York: Oxford, 2000, 286-293.

Scriber, Sylvia and Michael Cole. The Psychology of Literacy. Cambridge: Harvard University Press, 1981. 


\title{
Ira Shor
}

\section{ILLEGAL LITERACY}

\begin{abstract}
In this follow-up to previous essays, Shor proposes that BWbe mainstreamed into regular composition, with provisions made for the tutorial needs of students (following the fine work of Soliday, Gleason, Grego and Thompson). He argues that a BWempire has been created and driven by bogus testing and by prejudice. BW, often non-credit but still tuition-bound, is a remedial "sub-college" depressing the aspirations of working-class and minority students especially who are stigmatized as cultural deficits. Shor then proposes that first-year college writing courses should evolve into what he calls Critical Literacy Across the Community. This program would place writing into real contexts, connecting literate development to community-based, project-oriented activities.
\end{abstract}

It is the vanity of educators that they shape the education system to their preferred image. They may not be without influence but the decisive force is the economic system.

\section{- John Kenneth Galbraith (238)}

My daily life as a teacher confronts me with young men and women who have had language and literature used against them, to keep them in their place, to mystify, to bully, to make them feel powerless.

\section{- Adrienne Rich (63)}

English teachers are inclined to exaggerate the seriousness of error. Since the birth of the composition course in American education, the English teacher has been viewed as the custodian of "refined" usage... This emphasis upon propriety in the interest not of communication but of status has narrowed and debased the teaching of writing....

\section{- Mina Shaughnessy, Errors and Expectations (120)}

Again, the fact that African-Americans who had been "remediated" foundered at a much higher rate than whites suggests that we may need to reexamine assumptions behind first year programs designed to help at-risk students succeed in college.

$$
\text { - Eleanor Agnew and Margaret McLaughlin (49) }
$$

Ira Shor is Professor of English in the Ph.D. Program at the City University of New York and at the College of Staten Island. His most recent book is a tribute to Paulo Freire, Critical Literacy in Action (with Caroline Pari). For 1999-2000, he will be Distinguished Visiting Professor at William Paterson University. 
Driving in a snowstorm, my eyes studied the slippery road as the first blizzard of 2000 hit New York January 20. Through highway slush and a stiff wind, I drove from Brooklyn to the College of Staten Island, a low-rent campus where I taught BW for 15 years and still teach first-year comp. That cold January day, I was doing English advisement for Spring registration. The bad weather kept most students away so I had free time to prepare material for my upcoming comp courses. Then, around noon, a Black woman student wandered through the office door asking for help. Like many students (and like me), she was baffled at the unfriendly registration process - the closed courses, limited choices, numerous steps, complex financial aid, rising tuition, and frequently changing requirements. In the face of aggressive bureaucracy and the micro-management of public education, I usually follow Shor's First Democratic Rule-of-Thumb: When authorities change and impose rules faster than people can learn them, we're not obliged to pay attention. Our cluttered and clotted condition had to do with official control and with budget-cutting, not with the learning needs of teachers and students. Still, here was this student wanting help with a thicket of requirements and restrictions, and I was on duty. So, I began asking her questions.

In short, I found out that she was born and educated in Africa before enrolling at our college. She had failed the nefarious writing and reading entry tests originally imposed on us in 1978 after the early Open Admissions Wars at the City University of New York. Thanks to the latest war on CUNY, this woman who failed the writing and reading assessments was tracked into yet a new official arrangement called 'summer immersion' where she passed the remedial class but not yet the tests (one being a timed writing impromptu of 50 minutes offering two "agree or disagree' questions to students and the other being a reading comprehension of a supplied text). Apparently modest and seemingly harmless, these two tests produced immense failure over the years, generating the vast remedial empire that swallowed Open Admissions in the wake of 1978. This Black woman was one of the certified failures, but her case was not so simple.

You see, despite failing the entry exams, she had evaded the official prohibition against taking regular comp and had enrolled in the forbidden first-year comp course the semester before, where she managed a grade of $\mathrm{B}+$, a respectable achievement. She was making progress despite the rules which specified that the only writing class she could legally take was remediation, our zero-level BW courses. But, by hook or crook, she found her way into the regular class, English 111, where she got $\mathrm{B}+$ even though she was supposedly unprepared or unqualified. Now, in January, 2000, she wanted to register for our second required comp class, English 151, but had been finally caught and stopped by the counseling office, which blocked her registration according to 
the rules, and sent her to the English Department for advice.

To confirm her story on the spot, I brought up her transcript from our Department computer and saw the $\mathrm{B}+$ grade along with the $\mathrm{F}$ grades for the CUNY writing and reading tests. You can imagine my frustration and dismay. For two decades at CUNY, I had been opposing these bogus tests as illegitimate measures of student competence and as unfair obstacles to student achievement, but could not rouse faculty outrage against them, perhaps because many progressive junior faculty at CUNY had been fired in the fake fiscal crisis of 1976 . Now, in glorious $\mathrm{Y} 2 \mathrm{~K}$, the same old regime was leading us into the new century, declaring the student with me to be a cultural deficit while her transcript showed B+ in regular comp. As I just mentioned, she wanted now to slip quietly into 151 and continue progress towards her degree, but I lacked authority to override the University and College rules holding her back. I couldn't simply award her the passing grades she needed on the assessment tests to take the final level of regular comp. Her B+ in the first level of comp is not recognized as a substitute for passing the external checkpoint of the tests. She had been caught and detained, guilty of illegal literacy and unauthorized progress! Her small institutional offense of forbidden achievement loomed large enough to stop her registration. This ridiculous situation made me wish I had called in sick. As she stared at me waiting for relief, I couldn't face moving her backwards into another remedial course, so I advised her that she could take the tests again on her own instead of taking them through yet another non-credit, tuition-charging BW class. The testing office occasionally gives tests to extra-curricular walk-ins during the semester. I urged her to get whatever help she could at our tutoring center, do as much writing as she could in preparation for the tests, pass them come hell or high water, and then take the forbidden second comp class next term. She left the office polite but unsatisfied, thinking over what to do next, while I was thinking about early retirement.

I felt crummy and disgusted. I needed lunch and a break, but just then, another student came in for advisement, a white woman born in this country. I was astonished to find that she had the exact same problem as the African student who had just walked out! Can you believe that? I'm still marveling at the rotten coincidence. Her transcript showed her failing the writing and reading assessment tests yet getting into forbidden first-term comp, English 111, and earning there a B+ as well. She too was guilty of illegal literacy. Obviously, an academic crime wave was underway on our campus. For this new case of unauthorized achievement, I went through the same silly "advisement" all over again. Consider the resources wasted in producing such ridiculous academic experiences, for the students and for me. Our time is piddled away thanks to bogus testing and other repressive policies against Open Admissions at CUNY for the last three decades. I won't 
call these repressive policies "pointless" or "absurd" or "wrongheaded" or even "irrational" because there are reasons to them - conservative authorities imposing tuition, testing, and remediation to undermine public education and to suppress cultural democracy at a working-class institution, with its large non-white and female student groups. It's no accident that rising tuition, declining budgets, severe testing regimes, and empires of BW descended on CUNY when campuses filled with working students of the "wrong" color and gender after 1970.

The bias against low-income and dark-skinned students will take on a new face in Spring 2001 when the CUNY Writing Test will be replaced by a new regime. Then, all applicants scoring below 480 on the SAT or below 75 on the New York State Regents will have to take the ACT usage exam(short-answer) as well as the ACT writing sample(a timed impromptu). Students failing these will be directed to no-credit, tuition-charging private or public remedial programs where they will have one year to pass or else be denied admission to CUNY. This new regime may sweep 22 years of scandalous in-house testing under the rug of big-name tests (SAT, ACT, NY Regents). Essentially, it is old wine in new bottles, a cosmetic fix to put a pretty new celebrity face on an old, ordinary problem - the exclusion and subordination of working-class and minority students through testing and language arts. White supremacy will be maintained by the new regime because minority students have difficulty scoring above 480 on the culturally-biased SAT or above 75 on the NYS English Regents(attending as they do grossly underfunded inner-city high schools). The moral of this January story is apparent: A pedestrian program to enforce inequality and to end Open Admissions at CUNY is being replaced by a more glamorous and restrictive one that may make it harder for students to achieve legal or illegal literacy.

So, add my January story to the many complaints against official language policies that have accumulated over the years. First-year college writing courses in particular have provoked a "tradition of complaint," as Leonard Greenbaum called it some years ago. One early complaint came from the first President of the NCTE, Edwin Hopkins, in 1912. Unhappy with the workloads of writing teachers and the outcomes of writing classes, Hopkins wrote the lead article in the premier issue of English Journal, "Can Good Composition Teaching Be Done Under Present Conditions?" He answered his own question with a single word that began his essay: "No." Unfortunately, Hopkins's complaint was never resolved, insofar as "overwork and underpay" continue in the field, which began in the 1880s with writing teachers "oppressed, badly paid, ill-used, and secretly despised," according to Robert Connors (108). From this foundation, as Jim Berlin points out, a formidable empire of writing instruction grew, after Harvard imposed 
a written entrance exam in 1874 (failed by half who took it) and offered freshman comp in 1885 (which became the only required course there by 1897).

The recent history of BW takes its place in the legendary decades of complaint. I argue here and elsewhere that political conflict has shaped BW and first-year comp, creating oppressive conditions such as the phenomena of "illegal literacy" and "unauthorized achievement" reported above. Mainstream language arts with its punitive assessment and its correct usage model diverted literacy away from critical inquiry and democratic pedagogy, even though the patron saint of American education, John Dewey, weighed in on these questions early in the last century when comp and remediation were first settling into the landscape. Dewey's democratic and critical option was avoided as the field shaped itself around an elite correctness paradigm mentioned above by Shaughnessy. Facing this history, I contend that BW and the testing regimes that drive $\mathrm{BW}$ enrollments should be abolished by mainstreaming BW into untracked comp classes expanded with extra hours and tutorial services to meet all students' needs, based in the themes and idioms they bring to class (see Soliday and Gleason; Grego and Thompson; Glau; Elbow). Further, I propose that first-year comp evolve into what I call "Critical Literacy Across the Community," a field-based, project-oriented, ethnographic, community-action internship program which I outlined in a two-part interview with Howard Tinberg in TETYC (September and December, 1999). I won't reprise the Tinberg interview or my account of BW/comp from an an earlier $J B W(1997)$. Hopefully, readers will consult those sources for my arguments. Here, in this essay, to support my proposal for mainstreaming BW into untracked comp and for transforming comp into mentored writing internships in community-based projects, I offer four claims about the traditional courses dominating the field for the past century:

1. Writing instruction's focus on skills, correct usage, error, and the assimilation of students into academic discourse, actually represents a political process where the socialization of people into the status quo is at stake.

2. Writing instruction's vast and contentious terrain is dominated by practices which primarily serve the needs of an elite and not the majority of students and teachers despite notable resistance to and innovation against the predominant "correctness" paradigm.

3. Writing instruction's assessment instruments and remediation help reproduce inequality, which requires mass failure and illiteracy to preserve the unequal hierarchies now in place. 
4. Writing instruction's "failure" ("the tradition of complaint")is actually its success, insofar as mass miseducation and illiteracy help maintain the unequal system which originated, supervises, and finances regular comp as well as basic writing and bogus testing.

The importance of formal language arts to human development in our society is obvious. Language arts are constant requirements for students from elementary grades through college, making language instruction the biggest and most closely-watched enterprise in mass education. From childhood through early adulthood, official language arts help to socially construct how students see the world and act in it (Pattison; Rouse). This socialization through curriculum (what Paulo Freire called "the banking model" of pedagogy) uses assessment and instruction as vast "sorting machines," to borrow Joel Spring's metaphor. Because human beings are not easily sorted into subordinate lives, classrooms of the official syllabus are sites of conflict and resistance (Horner and $\mathrm{Lu}$ ). Thus, the tradition of complaint in first-year college writing is a product of the contention faced by the status quo in reproducing itself in each new generation.

For those writing teachers who want to teach against inequality and other regressive features of the status quo, I've been offering a number of books, such as Empowering Education (1992), When Students Have Power (1996), and Critical Literacy In Action (1999, with Caroline Pari). So, I won't detail here a critical pedagogy for questioning the status quo or for power-sharing in education. What I want to focus on at this moment is a central contradiction in mainstream pedagogy that helps account for its complaint-generating, conflict-making outcomes. As I see it, that central contradiction relates to an old Yiddish proverb, which says: "With one tuchas [behind], you can't dance at two weddings." Mainstream writing instruction is caught between two incompatible stories: the upbeat myth of opportunity and success for all through education versus the downbeat reality of unequal tracking and lesser results (especially for African-American students, as Agnew and McLaughlin noted, a racial outcome not examined by Baker and Jolly in their report on the effectiveness of BW). Literacy and schooling are officially promoted as ladders to success (as parts of the American Dream) but are unequally delivered as roads to very different lives depending on a student's race, gender, and social class. The majority of students in school come from non-elite backgrounds. Almost $60 \%$ of all American families live on $\$ 50,000$ or less each year; half live on less than $\$ 42,300$ (US Bureau of the Census, 1998, Tables 745, 746, 748, and 749). A student whose family is in the top fourth of the income bracket is 10 times more likely to graduate college by age 24 than is a student who comes from the bottom fourth (Mortenson).

Sorting-out the elite winners from the ocean of losers is a con- 
flict-ridden project for obvious reasons. In this undertaking, language instruction serves as one cultural practice among several which helps reproduce inequality. No system can take its own reproduction for granted, especially one with glaring inequities among the races, the genders, and the social classes. Such arbitrary hierarchies have to be normalized by ubiquitous institutions - like mass education and mass media - which occupy the time, space, action, and attention of everyday life. The arbitrary becomes ordinary by virtue of institutional routine and punished deviation, what Foucault (1980) spoke of as the daily "capillary" experiences of life in the system. In this routine regeneration of hierarchies, formal education in general and writing classes in particular help bond or capture students and teachers to a stratified status quo. This cultural capture-ubiquitous, routine, often messy, and certainly costly - works better in some times and places than in others, notably breaking down in the 1960s and notably ineffective in inner-city high schools at the turn of $\mathrm{Y} 2 \mathrm{~K}$. In reproducing itself daily, any system certainly does not start from scratch, but rather from a history of accumulated assets and liabilities in directing the unequal order of things. In the case of writing classes, such curricula have evolved for more than a century as political assets or cultural tools or institutional weapons, which Bourdieu (1991) called "symbolic violence" and which Freire $(1970,1998)$ called "cultural action," helping to construct self-in-society and society-in-self. The political issue here, from a Freirean point of view especially, is the contention between "cultural action for freedom" and "cultural action for domination." The pedagogical issue, from a Deweyan point of view, is the difference between a teacher "pouring in" official facts and skills into students versus constructing knowledge and inquiring habits of mind with them.

As it happened, the spread of remediation and testing in the last few decades coincided with a substantial widening of the income and wealth gaps between the top, middle, and bottom sectors of the population (US Bureau of the Census, 1998, Table 747). In the context of this growing inequity in a period I've called "the conservative restoration" (see Culture Wars), public education and its writing classes have been disciplined to support more official control and more tracking. In the assault on equality after the 1960s, language arts were targeted by a top-down back-to-basics campaign that tilted policy toward correctness and testing, though notable dissent in the name of critical inquiry, collaborative learning, and process research took shape from the bottom up. If those dissident elements actually dominated the field of writing instruction, millions of students might be oriented to social inquiry in language arts instead of to skill drills, perhaps militantly questioning why family incomes have barely budged since the 1970s; or, why great wealth coexists with 45 million designated as "working poor"; or, why vast food production coexists with deep hunger now 
affecting some 30 million Americans, including 12 million children; or, why American workers put more hours on the job than any other nation's workforce. All in all, then, I propose that a century of complaint against college language arts has largely missed the point because writing instruction has in fact been working from the top down to protect the elite and to maintain inequality but not from the bottom up to develop democracy and to level disparities. This suggests that the dominant writing pedagogy for the last hundred years - refined usage (as Shaughnessy observed above), basic skills, grammar drills, abstract forms like the 5-paragraph essay, bogus literacy assessment like fill-in-the-blank tests and impromptu timed writing exams, and teachercentered syllabi-is a curriculum for producing failure for the majority.

Shaughnessy's original doubts about the traditional approach anticipated the critique of "general writing skills instruction" (GWSI) made later by various scholars in Reconceiving Writing (1995). Shaughnessy put it like this:

The term "basic writing" implies that there is a place to begin learning to write, a foundation from which the many forms and styles of writing rise, and that a college student must control certain skills that are common to all writing before he takes on the special demands of a biology or literature or engineering class. I am not certain this is so. Some students learn how to write in strange ways. ("Some New Approaches Toward Teaching" 103)

Shaughnessy went on to describe how one "weak" student followed an interest in medicine to do health research which led to a long report on Egyptian mummies. "The paper may not have satisfied a professor of medical history," Shaughnessy wrote, "but it produced more improvement in the student's writing than any assignments I could have devised" (103). If mass achievement and critical literacy were the desired outcomes, then a very different writing enterprise would occupy the center of the field, one not dominated by refined usage and GWSI (the notion that there are general writing skills that can be taught abstractly and then applied technically in other contexts - see Agnew and McLaughlin for one study of how "successfully remediated" students were unable to transfer their BW skills to other courses). Writing instruction for democracy and critical literacy would be built around small classes, close mentoring by instructors all paid at full-time rates, power-sharing and problem-posing in the classroom, portfolio assessment, composing in real contexts, peer feedback, interdisciplinary action projects on and off campus, student-based themes, experimental methods, and inquiry into the gender, race, and class conditions of the 
students.

In making this argument about the structured inequality offered to the majority of students, I am certainly not the first to put forward such an analysis but follow a group of "revisionist" scholars whose work during and after the 1960 s revaluated education as a product of an unequal status quo. Even before revisionists like Katz, Spring, Greer, and Bowles and Gintis gained attention, sociologist Burton Clark (1960) offered his famous analysis of the "cooling-out function" in higher education. Clark examined how one community college "cooled-out" students it construed as "latent terminals." On the campus he studied, Clark found an elaborate and unacknowledged "cooling-out" process downwardly managing student goals through testing, counseling, and courses:

In one junior college, the initial move in a cooling-out process is pre-entrance testing; low scores on achievement tests lead poorly qualified students into remedial classes. Assignment to remedial work casts doubt and slows the student's movement into bona fide transfer courses. The remedial courses are, in effect, a subcollege. The student's achievement scores are made part of a counseling folder that will become increasingly significant to him. An objective record of ability and performance begins to accumulate. (572)

Note how entry-level assessment initiates "cooling-out" and how remediation continues the pressure on students to accept lesser options like vocational training or even dropping-out. In this famous early work, Clark detailed how "cooling-out" was a bureaucratic process of gatekeeping, diverting non-elite students from upwardly-mobile liberal arts to downward choices. Later on, Clark (1978) eventually made peace with the dubious practice of "cooling-out" because he saw the mass denial of college degrees as necessary for social stability in a system promoting and denying majority success at the same time, encouraging high ambitions while distributing limited rewards. Clark's accommodation to cooling-out was partly echoed in Brint and Karabel's study of mass higher education, The Diverted Dream (1989):

A more democratic community college would not, it should be emphasized, be a place where the "cooling-out" function has been abolished. As long as American society generates more ambition than its economic structure can absorb, the community college will be actively involved in channeling the aspirations of students away from four-year colleges and universities. Yet this said, there is something deeply troubling, especially in a society that prides itself on its openness, about 
the covertness of the cooling-out process as it now operates. (231)

Brint and Karabel called for "transparency" rather than subterfuge, suggesting that each college should publish its attrition, transfer, and graduation rates so students know what to expect. (Perhaps this would also mean that colleges publish the number of students who make 'illegal progress' - that is, those students who fail the official assessment exams but evade BW for regular comp and do well there anyway.) This openness is certainly a good idea, but still too accommodating to the unequal provision for mass literacy, where the standard curriculum rewards the already-privileged and miseducates the majority, as Dewey and Freire observed in separate times.

Actually, cooling-out was underway before Clark named the practice in the late 1950s. By 1900, colleges used first-year writing as a gatekeeper to university degrees (Crowley, 1991, 1995). First-year courses evolved remedial and regular tracks, testing regimes and textbook protocols, skill-based approaches to curriculum, producing the mass educational failure functional to a system that promised more opportunity than it could deliver. To make matters only worse, the dual writing empires of First-year Composition and Basic Writing not only "work" ironically insofar as they downwardly fail the non-elite, but they have been built through the gross labor inequity mentioned earlier, that is, the exploitation of adjunct writing teachers whose pay and status are woefully below those of full-time faculty (Trainor and Godley; Schell; Leatherman).

Where does this leave the future of BW? First, we have to teach for democracy and equality and against the status quo. Choosing democracy and equality means language arts that explicitly challenge the unequal order of school and society, disrupting the testing and tracking regimes that have captured writing instruction, experimenting with alternative pedagogies based in student idioms and conditions while sharing power with them. Parts of our field have already been implementing some critical alternatives to the BW and comp now predominant. What remains to be done are big jobs - eliminate bogus testing, mainstream BW into an expanded, untracked form of comp, then transform comp into "Critical Literacy Across the Community" so that students write in the context of real action projects, like producing newspapers, or doing ethnographies of worksites, homeless shelters and food pantries, or chronicling how a community organization developed the child care services needed by local parents, or producing informational pamphlets targeted for groups without their own research facilities (see Odell; Flower; Adler-Kassner, Crooks, and Watters; Claus and Ogden).

We learned important things about writing instruction in the last 
30 years, so we're better equipped now than ever to develop community-based critical literacy for democratic change. From the bottom up, in alliance with students and other groups, full-time and part-time teachers can invent new curricula and can build on the best practices in a field still dominated by bogus testing, tracking, correct usage, skillbased dead-ends, and exploitation of adjunct labor. Harvard's $19^{\text {th }}$ Century model of comp controlled college teachers and students in the $20^{\text {th }}$ Century. It will control us in 2100 unless we make other plans.

\section{Works Cited}

Adler-Kassner, L., R.Crooks, and A. Watters. Writing the Community: Concepts and Models for Service-Learning in Composition. Washington, DC: American Association of Higher Education, 1997.

Agnew, Eleanor, and Margaret McLaughlin, "Basic Writing Class of '93 Five Years Later: How the Academic Paths of Blacks and Whites Diverged," Journal of Basic Writing, 18.1 (1999): 40-54.

Baker, Tracey, and Peggy Jolly. "The 'Hard Evidence': Documenting the Effectiveness of a Basic Writing Program." JBW, 18.1 (1999): 27-39.

Berlin, James A. Rhetoric and Reality: Writing Instruction in American Colleges, 1900-1985. Carbondale, IL: Southern Illinois UP, 1987.

Bourdieu, Pierre. Language and Symbolic Power. Ed. John B. Thompson. Trans. Gino Raymond and Matthew Adamson. Cambrdige, MA: Harvard UP, 1991.

Bowles, Samuel, and Herbert Gintis. Schooling in Capitalist America, New York: Basic, 1976.

Brint, Stephen, and Jerome Karabel, The Diverted Dream: Community Colleges and the Promise of Educational Opportunity in America, 19001985, New York: Oxford UP, 1989.

Clark, Burton. "The Cooling-Out Function in Higher Education." American Journal of Sociology, 65 (1960): 569-576.

- - - "The Cooling-Out Function Revisited," in New Directions for the Community Colleges, ed. George Vaughan, San Francisco: JosseyBass, 1978.

Claus, Jeff, and Curtis Ogden, eds. Service Learning for Youth Empowerment and Social Change. New York: Lang, 1999.

Connors, Robert J., "Overwork/Underpay: Labor and Status of Composition Teachers since 1880," Rhetoric Review, 9.1 (Fall, 1990): 108125.

Crowley ,Sharon. "A Personal Essay on Freshman Composition." Pretext 12 (1991): 155-176.

- - -. "Composition's Ethic of Service, the Universal Requirement, and the Discourse of Student Need." Journal of Advanced Composi- 
tion, 15.2 (1995): 227-239.

Dewey, John. Democracy and Education. 1916. New York: Free Press, 1966.

Elbow, Peter. "Inviting the Mother Tongue: Beyond 'Mistakes,' 'Bad English,' and "Wrong Language." Journal of Advanced Composition, 19.3 (1999): 359-388.

Flower, L. "Literate Action." Composition in the Twenty-first Century: Crisis and Change. Eds. Lynn Z. Bloom, D.A.Daiker, and E.M. White. Carbondale, IL: Southern Illinois UP, 1996, 249-260.

Freire, Paulo. "Cultural Action for Freedom." 1970. Reprinted in the Harvard Educational Review, 68.4 (1998): 476-521.

Galbraith, John Kenneth. The New Industrial State. Boston: HoughtonMifflin, 1967.

Glau, Gregory, "The 'Stretch Program': Arizona State University's New Model of University-Level Basic Writing Instruction," WPA 20.1/ 2 (1996): 79-87.

Greenbaum, Leonard. "A Tradition of Complaint." College English 2 (1969): 174-187.

Greer, Colin. The Great School Legend, New York: Penguin, 1972.

Grego, Rhonda and Nancy Thompson. "Repositioning Remediation: Renegotiating Composition's Work in the Academy." College Composition and Communication, 47.1 (1996): 62-84.

Horner, Bruce, and Min-Zhan Lu. Representing the "Other": Basic Writers and the Teaching of Basic Writing. Urbana, IL: National Council of Teachers of English, 1999.

Hopkins, Edwin. "Can Good Composition Teaching Be Done Under Present Conditions?" The English Journal 1 (1912):1-10.

Katz, Michael. The Irony of Early School Reform. Cambridge, MA: Harvard UP, 1968.

Leatherman, Courtney. "Part-Timers Continue to Replace Full-Timers on College Faculties." Chronicle of Higher Education. January 28, 2000. A18.

Mortenson, Thomas. Postsecondary Education Opportunity. Iowa City, IA: American College Testing Program, 1998.

Odell, Lee. "Basic Writing in Context: Rethinking Academic Literacy." JBW14.1 (1995): 43-56.

Pattison, Robert. On Literacy: The Politics of the Word from Homer to the Age of Rock. NY: Oxford UP, 1982.

Rich, Adrienne. "Teaching Language in Open Admissions." In On Lies, Secrets, and Silence. New York: Norton, 1979.

Rouse, John. "The Politics of Composition." College English 41.1 (1979): 1-12.

Schell, Eileen. "The Costs of Caring: 'Femininism' and Contingent Women Workers in Composition Studies," in Feminism and Composition Studies: In Other Words. Eds. Susan Jarratt and Lynn 
Worsham, NY: MLA, 1998: 74-93.

Shaughnessy, Mina. Errors and Expectations: A Guide for the Teacher of Basic Writing. NY: Oxford UP, 1977.

- - - . "Some New Approaches Toward Teaching Writing," JBW6.1/ 2 (Fall/Winter, 1980): 103-116.

Shor, Ira., Empowering Education, Chicago: U of Chicago P, 1992.

- - - . Culture Wars: School and Society in the Conservative Restoration, 1969-1991. Chicago: U of Chicago P, 1992.

- - - . When Students Have Power. Chicago: U of Chicago P, 1996.

- - -. "Our Apartheid: Writing Instruction and Inequality." JBW16.1 (1997): 91-104.

Shor, Ira, and Caroline Pari, eds. Critical Literacy in Action: Writing Words, Changing Worlds. Portsmouth, NH: Heinemann/Boynton-Cook, 1999.

Soliday, Mary. "From the Margins to the Mainstream: Reconceiving Remediation." CCC 47.1 (1996): 85-100.

Soliday, Mary, and Barbara Gleason. "From Remediation to Enrichment: Evaluating a Mainstreaming Project," JBW16.1 (Spring, 1997): 64-78.

Spring, Joel. Education and the Rise of the Corporate State. Boston: Beacon, 1972.

- - - The Sorting Machine Revisited: National Educational Policy Since 1945. 1980; White Plains, NY: Longman, 1989.

Tinberg, Howard. "An Interview with Ira Shor-Part I." Teaching English in the Two-Year College 27.1 (1999): 51-60.

- - - . "An Interview with Ira Shor-Part II." Teaching English in the Two-Year College 27.2 (1999): 161-175.

Trainor, Jennifer Seibel, and Amanda Godley. "After Wyoming: Labor Practices in Two University Programs." CCC 50.2 (1998): 153-181.

Tyack, David B. The One Best System: A History of American Urban Education. Cambridge, MA: Harvard UP, 1974.

US Bureau of the Census, Statistical Abstract of the United States: 1998 (118 ${ }^{\text {th }}$ edition): Washington, DC, 1998. 


\title{
Lynn Quitman Troyka
}

\section{HOW WE HAVE FAILED THE BASIC WRITING ENTERPRISE}

\begin{abstract}
This "open letter" to the coeditors of JBW and the field of basic writing generally outlines four ways we have failed the basic writing (BW) enterprise: 1) by giving insufficient attention to public relations; 2) by allowing ourselves to be co-opted by traditional academic politics; 3) by not unraveling the confusion of legitimate differences of dialect with "bad grammar"; and 4) by not taking a more critical and enterprising approach to research. But this account of failures should not obscure the success of teachers, whose dedication to and achievements in the BWenterprise have been truly great.
\end{abstract}

April 2000

Dear George and Trudy:

We've not been getting good news, have we? At our home base, the City University of New York (CUNY), the retreat from a thirtyyear tradition of Open Admissions (OA) is complete. And now CUNY has been severely crippled by the draconian decision to cut back on what central administration and the Board of Trustees still insist on calling "remediation" programs. Senior colleges are under orders to dismantle their often nationally acclaimed basic skills programs for underprepared students. No longer can students in our senior colleges find review courses that often greatly increase their chances for successful college careers and employment. Yes, CUNY's community colleges, with their model basic skills programs, can still offer developmental courses. ${ }^{1}$ One small administrative matter has been overlooked, however: Our community colleges have been hit, with only a few months' warning, with exponential increases in enrollment that threaten to choke the system.

Unfortunately, CUNY is not alone in such responses to a backlash, both public and academic, against basic skills instruction in col-

Lynn Quitman Troyka earned her Ph.D. at New York University. She started teaching at Queensborough Community College, CUNY in 1968, two years before CUNY launched Open Admissions. By now, she is now a full-time writer, and occasional part-time adjunct. She served as chair of College Composition and Communication (CCCC) in 1981; chair of the College Section of the National Council of Teachers of English (NCTE) in 1988 and 1989; chair of the Modern Language Association's Division on the Teaching of Writing in 1989; and the Two-Year College English Association (TYCA) in 1997. She now chairs the CCCC Committee on Project Mentor. Since 1970, she has published developmental English textbooks, freshman English handbooks, and numerous essays in books and journals. 


\title{
Lynn Quitman Troyka
}

\section{HOW WE HAVE FAILED THE BASIC WRITING ENTERPRISE}

\begin{abstract}
This "open letter" to the coeditors of JBW and the field of basic writing generally outlines four ways we have failed the basic writing (BW) enterprise: 1) by giving insufficient attention to public relations; 2) by allowing ourselves to be co-opted by traditional academic politics; 3) by not unraveling the confusion of legitimate differences of dialect with "bad grammar"; and 4) by not taking a more critical and enterprising approach to research. But this account of failures should not obscure the success of teachers, whose dedication to and achievements in the BWenterprise have been truly great.
\end{abstract}

April 2000

Dear George and Trudy:

We've not been getting good news, have we? At our home base, the City University of New York (CUNY), the retreat from a thirtyyear tradition of Open Admissions (OA) is complete. And now CUNY has been severely crippled by the draconian decision to cut back on what central administration and the Board of Trustees still insist on calling "remediation" programs. Senior colleges are under orders to dismantle their often nationally acclaimed basic skills programs for underprepared students. No longer can students in our senior colleges find review courses that often greatly increase their chances for successful college careers and employment. Yes, CUNY's community colleges, with their model basic skills programs, can still offer developmental courses. ${ }^{1}$ One small administrative matter has been overlooked, however: Our community colleges have been hit, with only a few months' warning, with exponential increases in enrollment that threaten to choke the system.

Unfortunately, CUNY is not alone in such responses to a backlash, both public and academic, against basic skills instruction in col-

Lynn Quitman Troyka earned her Ph.D. at New York University. She started teaching at Queensborough Community College, CUNY in 1968, two years before CUNY launched Open Admissions. By now, she is now a full-time writer, and occasional part-time adjunct. She served as chair of College Composition and Communication (CCCC) in 1981; chair of the College Section of the National Council of Teachers of English (NCTE) in 1988 and 1989; chair of the Modern Language Association's Division on the Teaching of Writing in 1989; and the Two-Year College English Association (TYCA) in 1997. She now chairs the CCCC Committee on Project Mentor. Since 1970, she has published developmental English textbooks, freshman English handbooks, and numerous essays in books and journals. 
lege. Although my focus is on CUNY, I write this open letter, to express my condolences to you, me, and all readers of $J B W$, and I write to share my reflections on why this terrible retreat has happened. You asked me, George and Trudy, to address the question of where I think Basic Writing (BW) has been and is going. ${ }^{2}$ (And, by the way, I join you in wincing at the pun "W[h]ither BW?"). This prompt has forced me to organize and give voice to my felt sense that we BW faculty have collectively failed the BW enterprise. I'm as much at fault as my esteemed colleagues. We've let our vision blur and our idealism be put aside.

I want to say at the start that you two, as current coeditors of the Journal of Basic Writing (JBW), are not on my list of four ways I think we've failed the basic writing enterprise. Nor are Peter Miller and Bill Bernhardt, the $J B W$ coeditors before you from 1989 to 1995 . As $J B W$ editor in the mid-to-late 1980s, I know first hand that juried journals such as $J B W$ publish the best essays offered by colleagues and/or solicited by editors. ${ }^{3}$

The net I cast for these personal reflections has caught more than a single journal, college, event, or person. In my net are my years teaching BW at Queensborough Community College (QCC), one of 17 postsecondary schools that comprise CUNY; my synthesis of thirty years of reading the popular press and professional literature; my having attended lots of regional and national conferences, often as an elected leader in the sponsoring professional associations; and my having visited hundreds of US and Canadian colleges and universities as consultant and/or workshop leader.

Be warned, therefore. This open letter is subjective to the core.

At the start of OA, we BW faculty, researchers, and cheerleaders joined eagerly in the basic enterprise at CUNY. Like us, many colleagues across the United States were doing the same. We were pragmatists, yet idealists. We were egalitarians and believers in the power of language to give folks chances to make choices as individuals, consumers, and workers. "Enterprise" is a word I used in my title quite intentionally. To me, it's a term that connotes optimism, boldness in response to challenge, determination to persevere, and energy that stands undiminished when unexpected complexities threaten to hobble. Terms such as "establishment," "industry," "venture" don't do it for me: The first is too cynical, the second too commercial, the third too frail.

How did we fail our proud enterprise? Our first failure was we didn't tend to public relations. Did we think college students' need for BW and other basic academics would be accepted easily by our many publics? Didn't we realize that the vast majority of consumers of media, white and blue collar workers, professionals, homemakers, community leaders, legislators, educational administrators, and even faculty and students would be frankly repelled by what aspiring college students clearly did not know? Why did we not anticipate that the 
newspapers, eager to sensationalize, would jump on the chance to print examples of college basic writers' writing before they took catch-up courses?

I remember a mid-1970s complimentary profile in the New York Times about Mina Shaughnessy's compelling, foundational book about BW and basic writers, Errors and Expectations. The illustrations accompanying the article "just happened" to be samples of "before-BW" student writing. Predictably, most public reaction to that story and similar articles was negative. What are illiterate students doing in college? Won't an OA program that attracts such students water down the value of our hard-earned college degrees? Why are public funds being spent to repeat what students should have learned in high school "if only they had paid attention"? For months after that article appeared, I, along with my BW colleagues, was grilled with such questions when I saw friends or went to a social gathering of non-academics. Sadly, the tone was far more enraged and bitter when academics, particularly senior and almost senior faculty, got together. To this day, some thirty years later, these attitudes persist vocally.

But almost universally we supporters and teachers of college developmental courses were delighted with that newspaper article. We saw it as recognition and confirmation. In the face of the public's and senior faculty's responses, we simply sighed, shook our heads, thinking "What do they know?" Whatever each of us knew about learning from history evaporated.

A free society wants to be inspired on moral and practical grounds when something generous and constructive strikes so many as wrong. Clear information with specific supporting evidence, along with compelling stories, are vital for any new, semi-revolutionary movement, to take root and grow. The responsibilities of the pioneers, the semirevolutionaries, is to fill that need. Yet, we were silent. We didn't question whether samples of "before BW" circulating in the popular press needed to be countered with strong examples of "after BW." Even without the comfort of the sorts of quasi-scientific quantitative studies that educators used to love universally, we could have at least supplied alternative visual images for the public. Instances of student success in our BW classrooms evolved before our eyes. But we did not share them publicly. We remained silent.

We didn't write for the popular press, neither op ed pieces nor articles for widely read national magazines. We didn't try to get our story out on television and radio. We didn't doggedly seek to "prove" our results to college administrators who control policy and funding. We didn't attempt to curry favor with sympathetic political candidates who were likely someday to design public budgets. We didn't lobby sitting legislators, civic leaders, or grassroots influential organizations like Rotary Clubs and local business associations. We failed as com- 
municators.

Public relations were fine on another front, without effort. The story of OA and developmental programs mobilized hundreds of faculty at CUNY and many other colleges. Enthusiastically, we created curriculum and experimented with teaching strategies to serve our new student constituency. We searched for appropriate textbooks, with no luck - and we "settled" to keep things going. (I confess my first semester teaching BW, I settled for a collection of dull, mediocre readings merely because it was available in sufficient quantity at the college bookstore.) In reaction to the nonexistent teaching material we needed, we wrote our own fledgling resources. We succeeded often and fell flat at times, always trying to push ourselves ever closer to "what worked." Some of us even dared to publish college-BW textbooks, opening ourselves as novices to the scrutiny of our peers and students. We tried innovative teaching practices - collaborative learning, simulation games, freewriting, to name a few. Our internal public relations were fine.

Our second failure was we couldn't seem to find the strength to resist being appropriated by traditional academic culture. By implication, the newly hired faculty expected to teach basic skills ${ }^{4}$ were charged to find news ways to reach and teach developmental students. We collaborated, experimented, traded ideas and experiences. But after six or seven years, a round of CUNY budget cuts led to reassigning many of those full-timers to non-basic courses. Queensborough, my college, had in 1969 established a Basic Education Skills Department and was therefore less affected immediately, but as soon as faculty members left or retired, their positions were refunded for adjuncts. Soon far more than $50 \%$ of all basic skills courses were taught by adjuncts, many of whom were high school teachers during the day. Slowly, many CUNY colleges could not help but lose their innovative edge. Adjuncts were not paid to participate in faculty development, so we could not pass along easily what we full-timers had learned in the early years of OA. No expansion of criteria for promotion and tenure took place to recognize the creative, non-mainstream academic achievements of BW faculty.

At CUNY, new faculty energies began to steer toward traditional academic politics. Most of us BW faculty had come young to our assignments. We wanted to keep our jobs. We looked around, listened, and accurately concluded that our potential for promotion and tenure wouldn't benefit from our having spearheaded time-consuming alliances with high schools with whom we were eager to collaborate. We'd get no CV mileage out of writing the college textbooks desperately needed to fill a serious college-level pedagogic vacuum, no matter how groundbreaking the content and approach. We would have ventured too far afield had we spent time working toward what some of us envisioned as a way to universal literacy: a US Civilian Youth Corps. 
Academe for us was back to business as usual. This happened at many US colleges, not only those of CUNY. Couldn't we collectively have changed that reality by doing more than complaining among ourselves? We did not mobilize to demand that our administrators enlarge the playing field of traditional academic politics.

Our third failure, not unrelated to the issue of grammar yet extending far beyond it, was that too many of us beat a hasty retreat from the so-called "Black English (BE) controversy." It can be said to have begun in earnest in 1977 with the publication of Geneva Smitherman's Talkin and Testifyin: The Language of Black America. BE, sometimes called "Ebonics" today, describes the spoken dialect of some, but not all, African Americans. It operates with the same consistent, logical grammatical categories as do other languages and dialects, including so-called "standard English." BE has verb tenses, pronoun use, adjective and adverb placement, and so forth.

Smitherman's work quickly caught the attention of national media, which rarely reports on scholarly books as news. Most newspapers - even highly respected ones-published supposedly objective articles that in tone and emphasis were one step removed from mockery. Nothing was said about dialects being ubiquitous no matter what the language, today and throughout history. The examples chosen for the newspaper reports "just happened" to be ones that would appear relatively extreme to people unschooled in the history of linguistics.

Racist outrage and disgust laced the public's predictable outcry. Illiteracy! This proves inferiority! Non-African-American comedians joked on radio and television about $\mathrm{BE}$, and the jokes using $\mathrm{BE}$ phrases got the biggest laughs. As John McWhorter (among today's outstanding scholars of dialects) says "There is always a fundamental sense that they [dialects such as BE, "Joe Pesci's Brooklynese," and "Jeff Foxworthy's Southern 'redneck'"] are evidence of grungy mitts leaving their prints on the cool, clean formica of standard English" (ix).

In the 1970s at CUNY, many basic writers, though certainly not all, were African Americans. Today, they come from groups including African Americans, Latinos, Asians, Haitians, and many more according to geographic region and workforce. $\mathrm{BE}$, spoken dialect, found its way into the written work of some students. Those of us non-African Americans who seriously studied the scholarship in BE understood the logic behind the written "errors" of African Americans. In turn, we taught and teach parallels in structure between standard written English and BE. And we honestly talked about issues of economic mobility, offering choice rather than edict.

Given the academic politics I discussed earlier, too many BW faculty at CUNY and across the United States had neither time nor inclination to persevere in speaking out about the legitimacy of $\mathrm{BE}$ in the 
face of so intense a public, and academic, reaction. I wish more of us had pressed on, speaking out vigorously to educate the public in the scholarship of dialect, whether BE, varieties of British English, Creole, or dozens of others. ${ }^{5}$ I also wish the publication dates of Shaughnessy's and of Smitherman's books hadn't collided. Shaughnessy's 1977 book, highly influential among BW faculty, Errors and Expectations devotes its second half to teaching suggestions, some of which needed to be informed more thoroughly by scholarship in BE.

Our fourth failure related to research. Too often, we refused to look dispassionately at the results of pedagogic research studies from the 1960 s and before. We tended to swallow them whole, ignoring our knowledge of the inevitable limitations on applying outcomes. Let me give an example, the teaching of grammar, that has implications for appealing to public perceptions (and therefore, public relations) and for offering faculty opportunities for innovation (and therefore, affecting traditional academic politics).

Any layperson looking at the mid-1970s "before BW" images in the New York Times (picked up by the wire services) that accompanied the article about Mina Shaughnessy would conclude that the whole problem of underprepared writers is their rank ignorance of grammar. Often, I heard faculty who opposed OA say: "They're even too stupid to know correct grammar."

BW specialists knew such reactions were ignorant and simplistic. But in reaction, many took the easy way out. They openly declared that grammar didn't matter for writers. No nuances. So what if the public believes that grammar "matters"? Privately, some faculty, myself included, held a more relative view. But in influential circles, it became vogue for BW faculty to jump onto that ill-informed bandwagon. Many vocal colleagues drew on studies conducted in the $1960 \mathrm{~s}$ and earlier, well before OA and basic-skills college courses came into existence. Those studies, on the impact of teaching grammar on student writing, concluded that grammar instruction is a waste of time. Few asked key rigorous questions: How were those studies designed? Were groups of students matched and randomly assigned in pairs? Were the teachers assigned to groups randomly, no matter how firm their formal knowledge of English grammar and linguistics? These were interventional studies, so precisely what was the curricular content in the control and the experimental groups? What specific materials were used to teach and not teach grammar: error as sin? drill and kill? decontextualization from student writing? At least some, though not all, later studies of the effect of grammar knowledge on writing skills were well done. And as George Hillocks reminds us, based on his metaanalysis of 500 English instructional interventional studies, although teaching grammar is the least effective of the strategies, it should not 
be discounted entirely.

We erred by not asking such basic methodological questions. We erred, too, in reading public sentiment. We needed to take time to explain that "knowing" the rules of grammar mechanically wasn't the sole, or even a major, cause of substantive lapses in writing skills. The truth is far more textured. Hindsight, always $20 / 20$, tells us that one size does not fit all, or most. With today's research about learningstyles in mind $^{6}$, we can somewhat safely suggest that person A derives no benefit from grammar instruction; person $B$ benefits when the material is derived solely from student writing, most often his or her own; person $\mathrm{C}$ likes learning arcane facts about grammar and language in action for their own sake; and person D "gets it" best on his or her own privately with repetitive drill with self-checking. With recent research in the theory of Multiple Intelligences in mind ${ }^{7}$, we can responsibly hypothesize that persons $\mathrm{E}$ and $\mathrm{F}$ grasp concepts quickly and well if the information is presented visually, musically, or through other natural human modalities.

Another problem with research involved our choices of topics. Why did we recoil from the public's demand that we show results? Early on we could have built dossiers of anecdotal student successes. We wrongheadedly resisted one-semester "before and after" studies; had we looked a bit beyond our discipline, we might have put our heads together with educational psychologists and other scholars to try to invent creative, smart, and useful research designs. Instead, we did little. I imagine we kept hoping someone might come to our rescue. In 1997, someone did. The work took years, as it should have given its methodology, and it resulted in the most important BW research study to date: Marilyn Sternglass's Time to Know Them: A Longitudinal Study of Writing and Learning at the College Level. The book won the two top awards in our profession: the MLA Mina Shaughnessy Best Book of the Year Award and the College Composition and Communication's Outstanding Book of the Year Award. Sternglass's book, which convincingly demonstrates the benefits to students and society of OA goals, is often cited today and frequently assigned in graduate courses in the teaching of college composition. But in the interim, after Shaughnessy's Errors and Expectations until Sternglass's study, we didn't have the numbers or strength to hold back the flood of negative public and academic opinion.

Yet another problem with research had an impact at the BW classroom level. Tacitly understood limits on legitimate avenues for classroom research hampered some of us severely. I, for example, was intrigued by the potential in concepts of learning styles. I and a few others similarly interested were rebuffed, even ridiculed. We seemed to have entered an area deemed akin to witchcraft. To make things worse, 
review boards of respected academic journals were uninterested in all topics pedagogic. Happily, in 1984, thanks to the insight of Richard Larson, then editor of College Composition and Communication, we got to read the groundbreaking article by George Jensen and John DiTiberio "Personality and Individual Writing Processes." Thus began the legitimization of the subject. Their 1989 book further informed our teaching decisions. Today, learning-style awareness is firmly entrenched in all subjects at all levels of education, though too many college faculty still resist. I wish I had persevered, as I'm sure do colleagues intrigued by unusual areas such as "expanded perspectives on learning" do. For a sense of what could have been, see the stance in the formidable essay "'Building A Mystery': Alternative Research Writing and the Academic Act of Seeking."

Rather than end this open letter sounding like a total scold, I'd like to cite one area in which we did not fail the BW enterprise: teachers, the ones who labor daily in the vineyards. Usually unpublished (who has the time given their teaching loads of four or even five BW and freshman English classes a semester?), they are the ones who, student by student, make life-altering positive differences in the lives of students. They are the ones who after their first decade of BW teaching see former students reappear with their college-age child, or niece, or nephew in tow. "I want him/her to be in your class."

It is about such teachers, given the respectful label "practitioners" by Steve North in his Making of Knowledge in Composition, that lore is plentiful. Indeed, practitioners of teaching BW have many fine stories stored up. They tell of quiet successes, ones those teachers know are proof. Perhaps not data-ready, but proof nonetheless. Here's one: the husband of a BW teacher was once stuck in an interminable summer traffic jam. When drivers got out of their cars to commiserate, the husband pointed to the QCC decal on the rear window of the car in front of him and asked, "How'd you like that college?" The young driver said he was embarrassed to have had to leave to support his family by working two jobs. Then he added "I had one teacher, she taught us how to write and think analytically. I don't know her name, but she sticks in my memory because I really learned about writing and critical analysis." As icing on the cake, the husband pulled out of his wallet, showed the young driver his wife's photo, and heard "Where did you get that? She was my teacher!"

Such teachers genuinely like BW and basic writers. Perhaps they want to return to the community some of what it gave them as they grew up. Perhaps they greatly enjoy seeing students progress in the visible, often dramatic ways possible only in BW classes. Perhaps, above all, they sustain an active commitment to the notion that everyone should have the chance for equal access to economic, social, and political wisdom. 
Well, George and Trudy, I hope some folks who read this open letter will be moved to write you other letters. I hope they disagree or agree, adding their alternative views. And perhaps some will make practical proposals for the future, ones that seek to pull us together with a reasoned plan of repair and renewal (if it isn't too late and if enabling funds can be found).

With my warmest personal regards,

Lynn

\section{Notes}

1. Letter to author. 3 November 1999.

2. For a more detailed picture of the implications, particularly concerning racism and a two-tiered system, and impact of CUNY's decision, see "Remediation Phase-Out at CUNY: The 'Equity versus Excellence' Controversy," by Barbara Gleason.

3. In "Investigating Our Discursive History: $J B W$ and the Construction of the 'Basic Writer's' Identity," Laura Gray-Rosendale offers a trenchant analysis of $J B W$ s evolution. I look forward to other such analyses, perhaps from alternative, equally valid perspectives. By the way, I've intentionally not mentioned $J B W$ s early incarnation, titled Basic Writing $(B W)$, founded and edited for a few years by Mina Shaughnessy and later edited by Sara D'Eloia. $B W$ started our collective conversations about our emerging specialty. No matter the sometimes-heated, hindsight-driven debates they inspire, $B W$ issues are mostly considered defining historical artifacts to be honored.

4. The 1970 summer at Queensborough Community College, CUNY, the department's P\&B (Personnel and Budget) Committee, on which I served, almost daily interviewed applicants for full-time tenure-bearing positions. From the scores interviewed, our department of ten fulltime faculty tripled. A few summers later, we added more faculty.

5. I've recently discovered a brilliant book Spreading the Word, by McWhorter. In 78 pages, it offers a reasonably quick read from which to learn volumes about dialect, including BE. A taste of its clarity and accessibility is reflected in its four chapter titles: "I Hear So Much Bad Grammar These Days'"; "It's Just Slang, Isn't It?"; "'They Just Mix Them Up!'”; and "The Linguistic Rain Forest." 
6 . The research is plentiful by now. For direct application to the teaching of writing, see Jensen and DiTiberio in CCC; also see their book Personality and the Teaching of Composition. Theories of learning styles, also called cognitive styles, are plentiful. For a description of many of them see <http://web.indstate.edu/ctl/styles/model2.html>.

7. Howard Gardner, professor of psychology at Harvard, pioneered work on the theory of Multiple Intelligences (MI). Frames is a detailed description of the theory; Multiple Intelligences, my personal favorite, summarizes Frames in a concise, lucid opening chapter and then reports on many educational research projects that applied MI theory. Originally, Gardner identified seven intelligences; a few years ago he added an eighth. The latter is not discussed in either book I cite here. For a creative application of MI theory to teaching strategies for the English classroom, see Smagorinsky. For a detailed, creative application of Gardner's visual intelligence, see Image Grammar (with Interactive $(D$-Rom), by Noden.

\section{Works Cited}

Davis, Robert, and Mark Shadle. "'Building a Mystery': Alternative Research and the Academic Act of Seeking." College Composition and Communication 51 (2000): 417-49.

Gardner, Howard. Frames of Mind: The Theory of Multiple Intelligences. New York: Basic Books, 1983.

- - -. Multiple Intelligences: The Theory in Practice. New York: Basic Books, 1993.

Gleason, Barbara. "Remediation Phase-Out at CUNY: The 'Equity Versus Excellence' Controversy." CCC51 (2000): 488-91.

Gray-Rosendale, Laura. "Investigating Our Discursive History: JBW and the Construction of the 'Basic Writer's' Identity." Journal of Basic Writing 18.2 (1999): 108-35.

Hillocks, George. Research on Written Composition. Urbana: National Council of Teachers of English, 1986.

Jensen, George H., and John K. DiTiberio "Personality and Individual Writing Processes." CCC 35 (1984): 285-300.

- -. Personality and the Teaching of Composition. Norwood, NJ: Ablex, 1989.

McWhorter, John. Spreading the Word: Language and Dialect in America. Portsmouth: Heinemann, 2000.

Noden, Harry R. Image Grammar: Using Grammatical Structures to Teach Writing (with Interactive CD-ROM). Portsmouth, NH: Boynton/ 
Cook Heinemann, 1999.

North, Stephen M. The Making of Knowledge in Composition: Portrait of an Emerging Field. Upper Montclair, NJ: Boynton/Cook, 1987.

Otte, George, and Trudy Smoke. Letter to author. 3 November 1999.

Shaughnessy, Mina P. Errors and Expectations: A Guide for the Teacher of Basic Writing. New York: Oxford UP, 1977.

Smitherman, Geneva. Talkin and Testifyin: The Language of Black America. Boston: Houghton Mifflin, 1977.

Smagorinsky, Peter. Expressions: Multiple Intelligences in the English Class. Urbana, IL: National Council of Teachers of English, 1991. 


\section{News and Announcements}

Call for Papers: The Conference on Computers and Writing invites proposals for its $17^{\text {th }}$ annual conference, May 17-20, 2001. Hosted by Ball State University, the conference features the theme "2001: A Cyber Odyssey. Drawing on Arthur C. Clarke and Stanley Kubrick's 1968 landmark film 2001: A Space Odyssey, we invite inquiry into such questions as : what technologies have we adopted out of necessity?, what are our current choices?, which directions should we follow and which pitfalls should we avoid? We solicit proposals for individual presentations, panels, round tables, and hands-on workshops that extend and explore issues of technology and teaching. Please submit proposals via the conference website, www.bsu.edu/cw2001, by Oct. 17, 2000.

Call for Articles - Basic Writing e-Journal (BWe) The theme for the March, 2001 issue will be Who are "basic writing students", and what do they in basic writing classes? Articles for this issues might analyze, complicate, or otherwise explore the nature of writing in basic writing courses. Included might be explorations of innovative assignments and/or student writing, analyze the demographics of students in basic writing at particular institutions, analyze student essays from basic writing classes, or other projects related to student writing. We also invite articles from students in basic writing classes. Submissions for this issue should be received by January 15, 2001 and should be sent via Microsoft Word attachment to to Linda Adler- Kassner (adlerk@online.emich.edu). Other inquiries should be directed to the e-mail address above or to Greg Glau (gglau@asu.edu).

Workshop announcment: The Institute for Writing and Thinking Workshops at Bard College, Annadale-on-Hudson, NY Spring/Summer Workshops. Some of the topics Writing to Learn, Reading and Writing Nature, Writing to Learn Math and Science, Poetry: Reading, Writing, Teaching, July 9-14 Writing Retreat for Teachers, and Invention and the Art of Revision. For more information contact Ray Peterson at 914-758-7431 or peterson@bard.edu.

Conference Announcement: $5^{\text {th }}$ National Writing Centers Association Conference, November 2-4, 2000 at the Omni Harbor Hotel in Baltimore, Maryland. Theme is an exploration of issues of concern to those who work in writing centers. For conference information visit the web site at http://www.english.udel.edu/wc/mawca/ nwcacon.html or contact Terrance Riley at riley@planetx.bloomu.edu. 
Call for papers: JAC (A Journal of Composition Theory) invites submissions of articles on a variety of topics related to writing, rhetoric, multiple literacies, and culture. Use current MLA style and send three copies, stripped of identifying information to Professor Lynn Worsham, Editor, $J A C$, Department of English, University of South Florida, Tampa, FL 33620-5550. For additional information contact her at 813-974-9536 orLworsham@chuma1.cas.usf.edu

Call for articles: Written Communication is an international, multidisciplinary journal that publishes theory and research in writing from fields including anthropology, English, history, journalism, linguistics, psychology, and rhetoric. No worthy topic related to writing is beyond the scope of the journal. For detailed information about submissions, please see any recent issue of Written Communication, or visit our website: www.wisc.edu/english/composition/ written_communication/WCwebpg 


\section{Composition and Rhetoric Studies, Ph. D. Program in English}

\section{The Grailuate Genter of \\ The Gity University of New York}

For further information, write to: Composition and Rhetoric Area Group, English Program

Graduate School and University Center The City University of New York 365 Fifth Avenue New York, NY 10016-4309

Or, visit our English Program website: http://web.gsuc.cuny.edu/english/home.html

\section{Tel.: 212/817-8315}




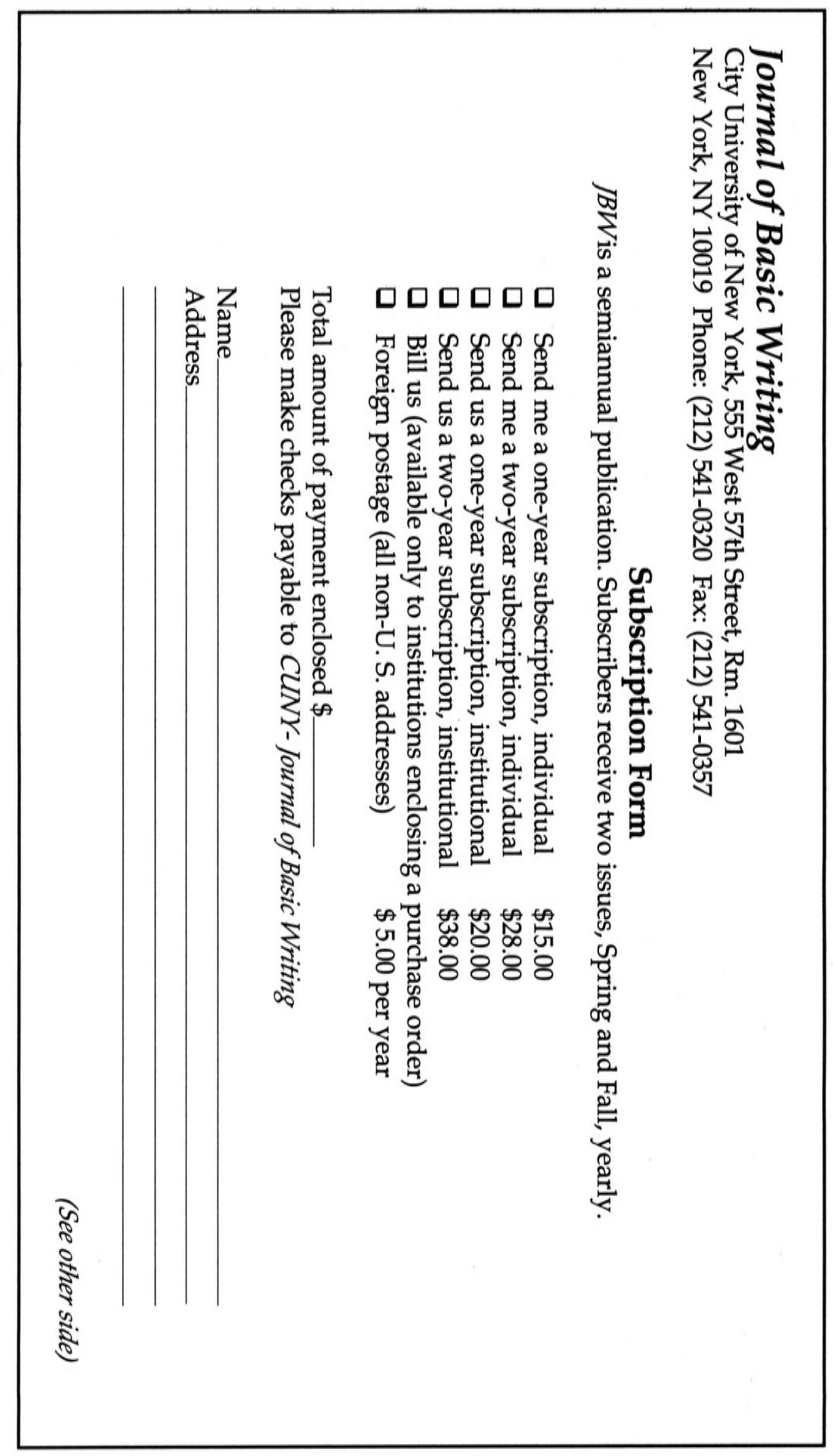




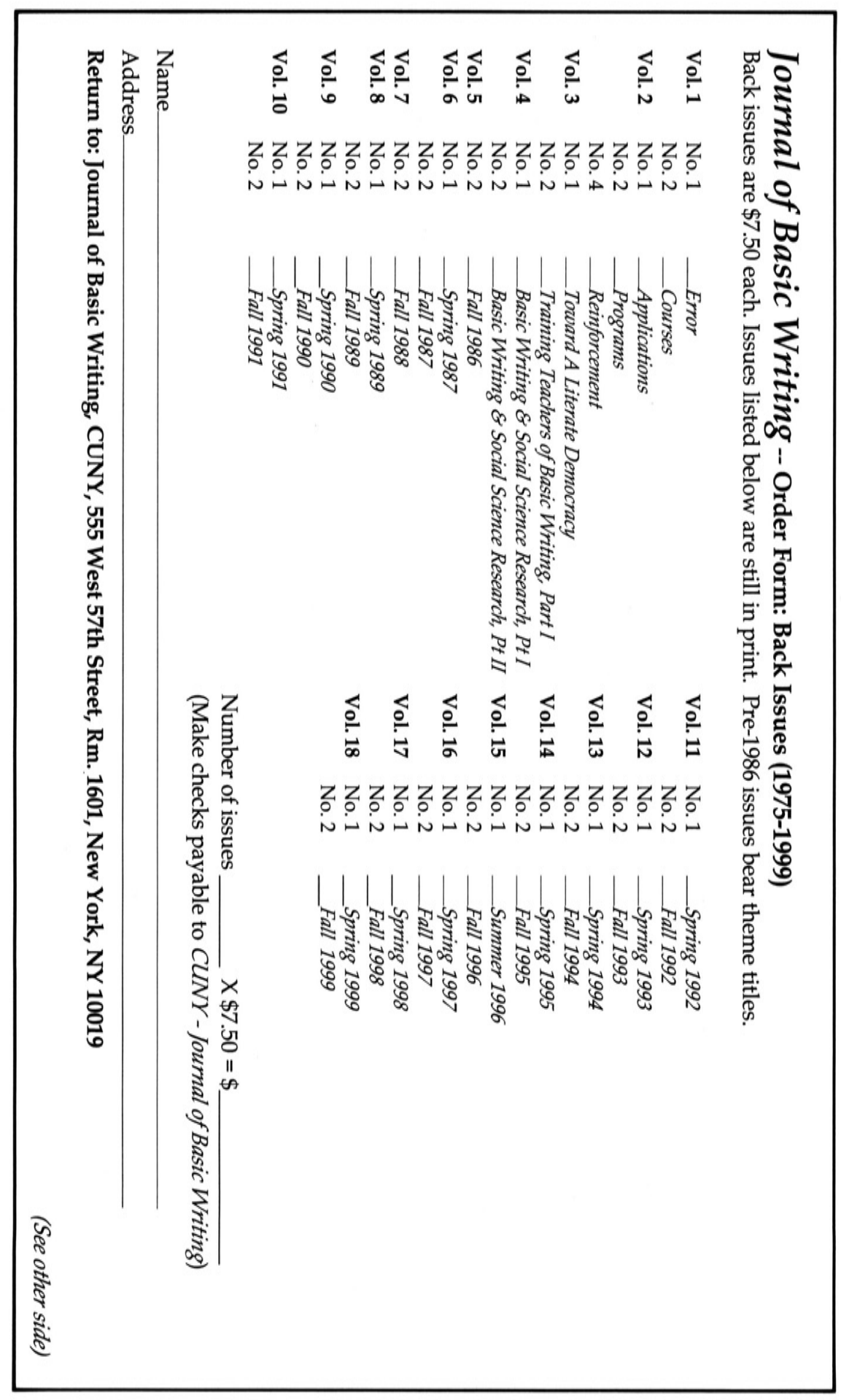



- 


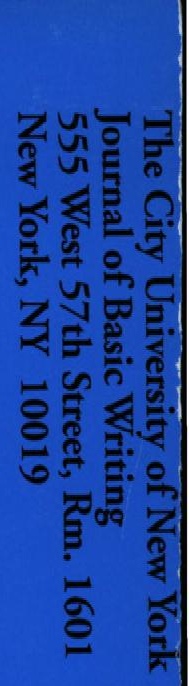

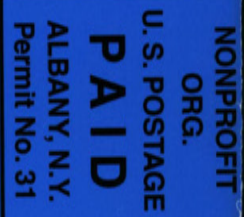

